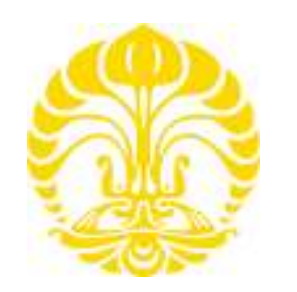

\title{
UNIVERSITAS INDONESIA
}

\section{DAMPAK PENERAPAN KEBIJAKAN EKONOMI DOI MOI DI BIDANG PELAYANAN PUBLIK TERHADAP PELAYANAN KESEHATAN DI VIETNAM: ANALISIS \\ IMPLEMENTASI DEKRIT 43 TAHUN 2006}

TUGAS KARYA AKHIR

DISUSUN OLEH:

MARIETTA RISANTI

1306384385

FAKULTAS ILMU SOSIAL DAN ILMU POLITIK

DEPARTEMEN ILMU POLITIK

PROGRAM SARJANA

DEPOK 


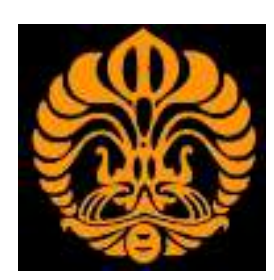

UNIVERSITAS INDONESIA

\section{DAMPAK PENERAPAN KEBIJAKAN EKONOMI DOI MOI DI BIDANG PELAYANAN PUBLIK TERHADAP PELAYANAN KESEHATAN DI VIETNAM: ANALISIS IMPLEMENTASI DEKRIT 43 TAHUN 2006}

Tugas Karya Akhir

Diajukan sebagai salah satu syarat memperoleh gelar sarjana Ilmu Politik

MARIETTA RISANTI

NPM: 1306384385

FAKULTAS ILMU SOSIAL DAN ILMU POLITIK DEPARTEMEN ILMU POLITIK PROGRAM SARJANA DEPOK 


\section{HALAMAN PERNYATAAN ORISINALITAS}

Tugas Karya Akhir ini adalah hasil karya saya sendiri, dan semua sumber baik yang dikutip maupun dirujuk

telah saya nyatakan dengan benar.

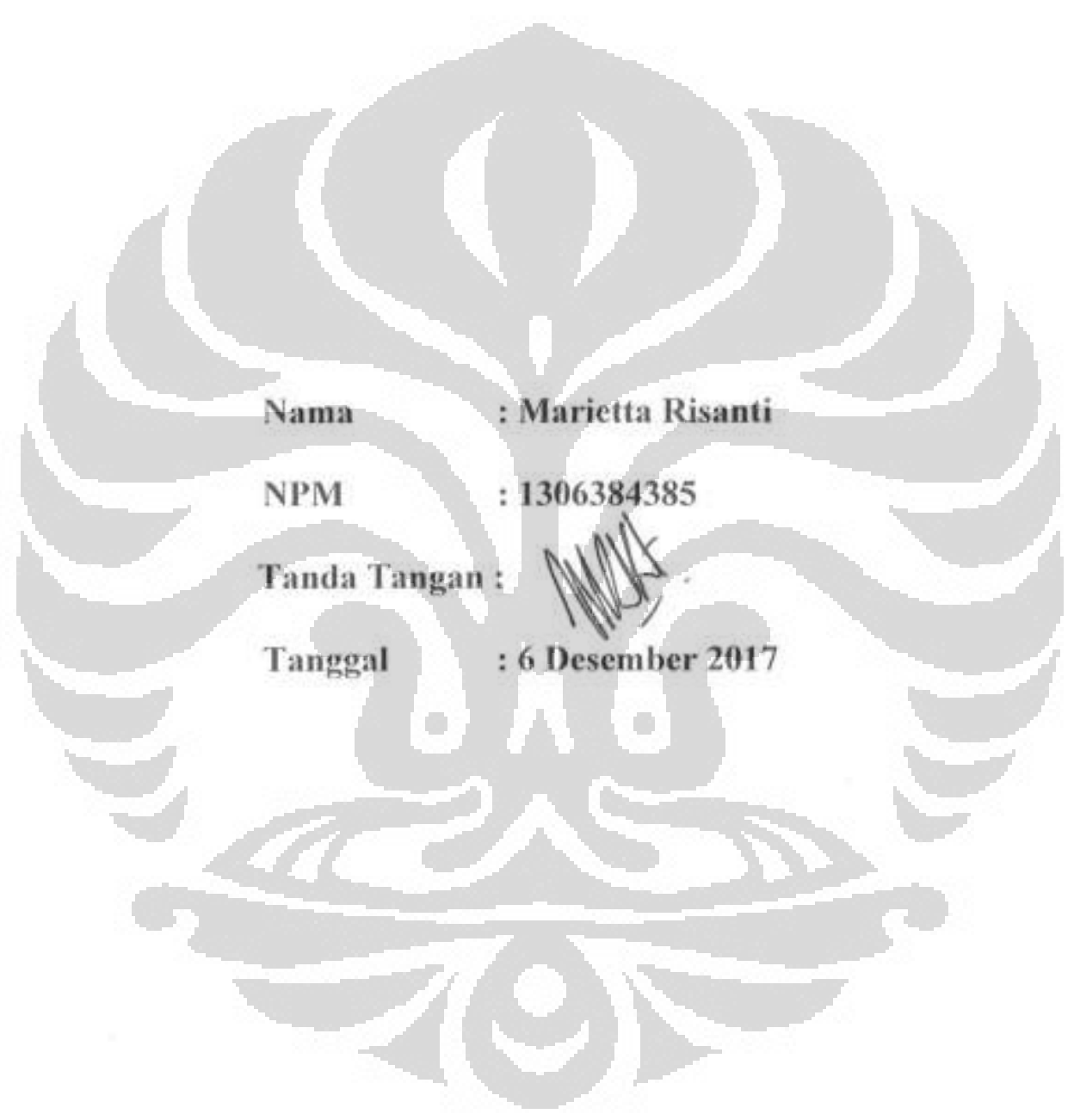




\section{HALAMAN PENGESAHAN}

TKA ini ditujukan oleh

Nama

: Marietta Risanti

NPM

: 1306384385

Program Studi

: Ilmu Politik

Judul Skripsi

: Dampak Penerapan Kebijakan Ekonomi Doi Moi di Bidang Pelayanan Publik terhadap Pelayanan Kesehatan di Vietnam: Analisis Implementasi Dekrit 43 Tahun 2006.

Telah berhasil dipertahankan di hadapan Dewan Penguji dan diterima sebagai bagian persyaratan yang diperlukan untuk memperoleh gelar Sarjana Ilmu Politik pada Program Studi Ilmu Politik Fakultas Ilmu Sosial dan Ilmu Politik, Universitas Indonesia

\section{DEWAN PENGUJI}

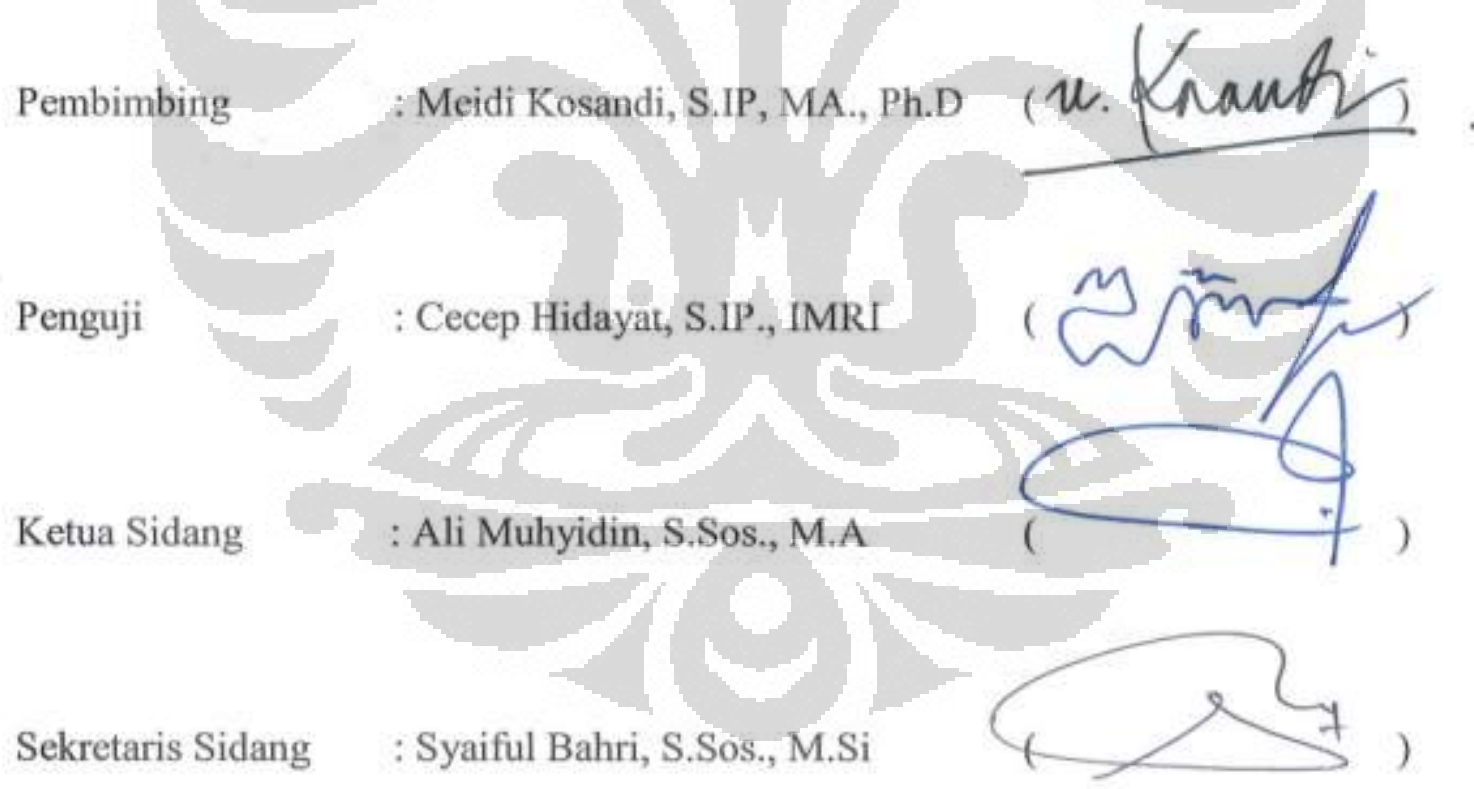

Ditetapkan di : Depok

Tanggal : 6 Desember 2017 


\section{KATA PENGANTAR}

Puji dan syukur saya panjatkan ke hadirat Allah SWT, karena atas berkat dan rahmatNya, saya dapat menyelesaikan Tugas Karya Akhir saya yang berjudul Dampak Penerapan Kebijakan Ekonomi Doi Moi di Bidang Pelayanan Publik terhadap Pelayanan Kesehatan di Vietnam: Analisis Implementasi Dekrit 43 Tahun 2006. Penulisan skripsi ini dilakukan dalam rangka memenuhi salah satu syarat untuk mencapai gelar Sarjana Ilmu Politik pada Fakultas Ilmu Sosial dan Ilmu Politik Universitas Indonesia. Banyak kekurangan yang tertulis dalam tugas karya akhir ini. Namun, atas bantuan yang telah diberikan oleh pembimbing saya dan orang tua saya, serta atas izin Allah SWT, maka saya dapat penyelesaikan tugas akhir ini. Selain itu juga saya berterima kasih kepada orang-orang terdekat saya yang selalu memberikan dukungan pada saya. Penulis mengucapkan terima kasih kepada:

1. Almarhum ayah saya, Mohamad Priatna yang telah memberikan saran bagi saya untuk belajar, menjadi teman saya untuk berdebat, berdiskusi, mendampingi saya dalam keadaan apapun untuk menyelesaikan pendidikan di Ilmu Politik Universitas Indonesia dan menjadi motivasi saya untuk lebih baik lagi. Lalu saya juga berterima kasih kepada ibu saya, Agung Irianti yang tidak hentihentinya mendoakan saya agar saya dapat menyelesaikan tugas akhir ini dengan sebaik-baiknya. Terima kasih kepada pacar saya, Adityamas Mahardika yang selalu mendukung saya, memberikan doanya, dan menghibur saya dikala saya ingin menyerah dan merasa tidak mampu menyelesaikan studi saya. Untuk adik saya, Deska Ramadhana, terima kasih karena telah mendukung saya untuk menyelesaikan studi agar saya dapat membimbing dia untuk belajar mengenai Ilmu Politik.

2. Terima kasih kepada nenek saya, tante-tante saya, sepupu-sepupu saya yang telah memberikan dukungan kepada saya agar saya mampu menyelesaikan studi ini dengan baik

3. Tidak lupa saya juga mengucapkan terima kasih kepada pembimbing saya Mas Meidi Kosandi yang dengan sabar membimbing saya untuk mengerjakan tugas 
akhir ini dan memberikan kritik serta sarannya yang sangat bermanfaat dalam studi saya.

4. Selain itu, ucapan terima kasih saya ucapkan juga kepada teman teman saya, yaitu Nadia, Samuel, Vicky Sewaka, Indah, Laras, dan tempat-teman saya yang lain dalam grup "PIKNIK". Terutama terima kasih yang sebesar-besarnya kepada Katin dan Puri yang telah dengan sabar memberikan saya kritik dan menjadi teman diskusi saya dikala saya bingung dalam membahas studi yang saya kaji.

5. Terima kasih juga pada seluruh dosen-dosen ilmu politik yang telah mengajarkan saya dan membimbing saya sehingga saya dapat memahami apa itu ilmu politik, serta belajar untuk mengetahui lebih dalam kasus-kasus yang terjadi dalam dunia perpolitikan dengan mengkaji permasalahan berdasarkan teori yang sesuai.

6. Serta terima kasih juga saya ucapkan kepada teman-teman saya di jurusan Ilmu Politik 2013 yang telah menjadi teman diskusi saya terkait perkuliahan.

Kepada seluruh pihak yang belum saya sebutkan namanya, saya mohon maaf sebesarbesarnya. Semoga penulisan ini dapat bermanfaat bagi orang-orang yang membacanya. Apabila ada kritik dan saran, dengan senang hati saya akan menerimanya sebagai proses belajar saya untuk ke depannya.

Depok, 6 Desember 2017

Penulis, 
Sebagai sivitas akademik Universitas Indonesia, saya yang bertanda tangan di bawah ini:

Nama : Marietta Risanti

NPM : 1306384385

Program Studi : Ilmu Politik

Departemen : Ilmu Politik

Fakultas : Ilmu Sosial dan Ilmu Politik

Jenis Karya : Tugas Karya Akhir

Demi pengembangan ilmu pengetahuan, menyetujui untuk memberikan kepada Universitas Indonesia Hak Bebas Royalti Non-ekskłusif (Non-exclusive Royalti Free Right) atas karya ilmiah yang berjudul :

"Dampak Penerapan Kebijakan Fkonomi Doi Moi di Bidang Pelayanan Publik terhadap Pelayanan Kesehatan di Vietnam: Analisis Implementasi Dekrit 43 Tahun 2006."

Beserta perangkat yang ada (jika diperlukan). Dengan Hak Bebas Royalti Noneksklusif ini Universitas Indonesia berhak menyimpan, mengalihmedia/format-kan, mengelola dalam bentuk pangkalan data (database), merawat, dan memublikasikan tugas akhir saya selama tetap mencantumkan nama saya sebagai penulis/pencipta dan sebagai pemilik Hak Cipta. Demikian pernyataan ini saya buat dengan sebenarnya.

Dibuat di : Depok

Pada Tanggal $: 24$ November 2017

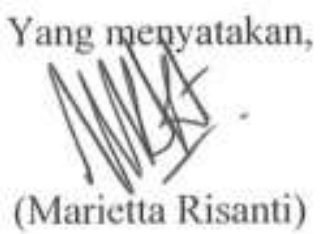




\begin{abstract}
ABSTRAK
Nama $\quad$ : Marietta Risanti

Program Studi : Ilmu Politik

Judul

: Dampak Penerapan Kebijakan Ekonomi Doi Moi di Bidang Pelayanan Publik terhadap Pelayanan Kesehatan di Vietnam: Analisis Implementasi Dekrit 43 Tahun 2006

Pembimbing : Meidi Kosandi, S.IP, MA., Ph.D

Penetapan kebijakan Doi Moi di Vietnam merupakan langkah awal dari Partai Komunis Vietnam untuk menaikkan perekonomian negara. Hal tersebut dilakukan dengan cara mengubah sistem perekonomian sentralistik menjadi desentralistik dan membuka liberalisasi perdagangan. Penerapan Doi Moi tidak hanya berdampak pada sektor ekonomi, namun juga pada sektor kesehatan yang ditunjukan dengan adanya ketidakmerataan akses terhadap layanan kesehatan. Pemerintah selanjutnya mengeluarkan Dekrit 43 Tahun 2006, mengenai otonomisasi badan usaha publik termasuk rumah sakit. Kebijakan tersebut diharapkan berfungsi sebagai solusi atas permasalahan layanan kesehatan pada saat itu. Penulisan ini akan menganalisis implementasi Dekrit 43 Tahun 2006, dengan menggunakan pendekatan kualitatif serta teori implementasi kebijakan publik yang digagas oleh Daniel A. Mazmanian dan Paul A. Sabatier. Hasil dari temuan penelitian ini adalah pemberian otonomi tersebut dianggap tidak berhasil karena masih terdapat komersialisasi layanan kesehatan, sehingga menyebabkan ketidakmerataan layanan kesehatan.
\end{abstract}

Kata kunci: Doi Moi; Kebijakan Publik; Otonomisasi; Pemerataan Layanan Akses Kesehatan. 


\begin{abstract}
Name $\quad$ : Marietta Risanti

Study Program : Political Science

Title : The Impact of The Implementation of Doi Moi's Economic Policy on Public Service for Health Services in Vietnam: Analysis of The Implementation of Decree 43 Year 2006
\end{abstract}

Counsellor : Meidi Kosandi, S.IP, MA., Ph.D

The implementation of Doi Moi's policy in Vietnam is the first step of the Communist Party of Vietnam to raise the country's economy, by transforming the centralized economic system into a decentralized system and opening a trade liberalization. The implementation of Doi Moi not only affects the economic sector, but also the health sector as indicated by the inequity of access to the health services. The government subsequently issued Decree 43 of 2006, about the autonomization of public business entities including hospitals. The policy is expected to work as a solution to health care problems at the time. However, after the policy is running, there is still commercialization of health services so that the implementation of health care policy fails. Based on the problems, this paper will analyze the implementation of Decree 43 of 2006, using a qualitative approach and the theory of public policy implementation created by Daniel A. Mazmanian and Paul A. Sabatier. The finding of this study is that the provision of autonomization towards public health care is unsuccessful. Considering after the implementation of the policy, the commercialization of health services is still there, causing an inequality of health services.

Keywords: Autonomization; Doi Moi; Equity of Public Health Services; Public Policy. 


\section{DAFTAR ISI}

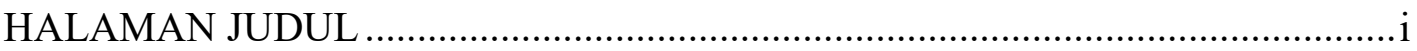

LEMBAR PERNYATAAN ORISINALITAS .........................................................ii

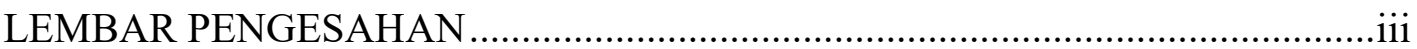

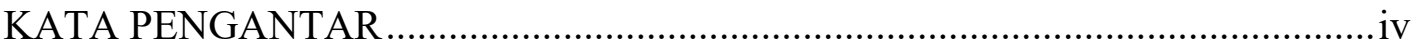

PERNYATAAN PERSETUJUAN ..................................................................

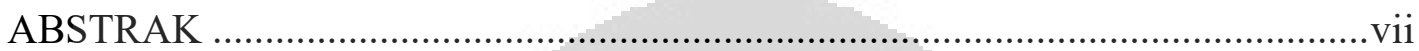

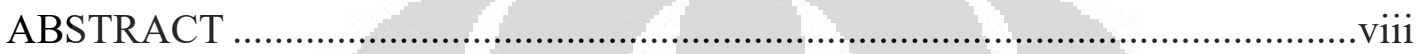

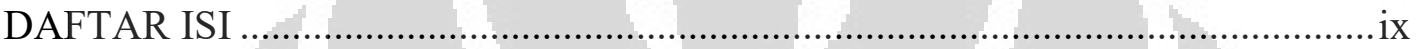

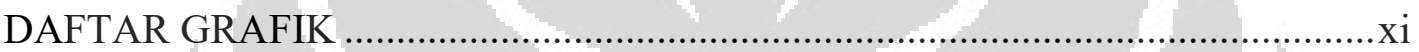

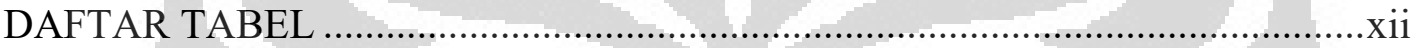

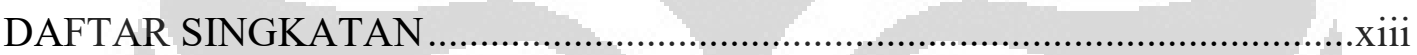

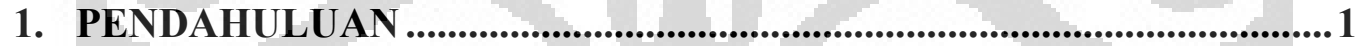

1.1 Latar Belakang Masalah ...................................................................... 1

1.2 Rumusan Masalah ......................................................................... 4

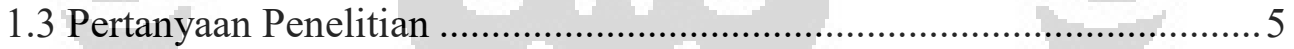

1.4 Tujuan dan Signifikansi Penelitian.................................................... 5

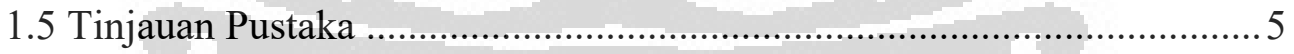

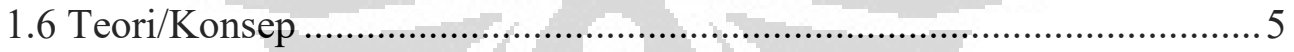

1.6.1 Konsep Kebijakan Publik ........................................................ 8

1.6.2 Implementasi Kebijakan ........................................................ 10

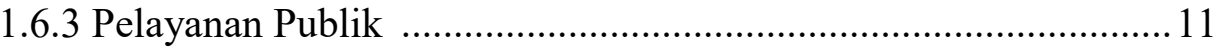

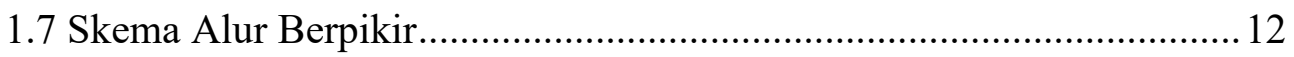

1.8 Metode Penelitian ................................................................................ 13

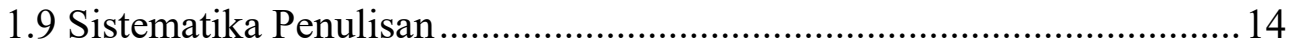


2. REFORMASI KEBIJAKAN DOI MOI DAN KOMERSIALISASI

LAYANAN KESEHATAN PASCA DOI MOI

2.1 Reformasi Kebijakan Doi Moi

2.2 Dampak Kebijakan Doi Moi Terkait Komersialisasi Bidang Kesehatan.

2.2.1 Anggaran Negara yang Tidak Seimbang Kepada Sektor

Kesehatan

2.2.2 Kesenjangan Akses Kesehatan

2.2.3 Sistem Asuransi yang Tidak Memadai.

3. IMPLEMENTASI

DEKRIT 43 TAHUN 2006 TERHADAP LAYANAN KESEHATAN ..35

3.1 Aturan Terkait Layanan Kesehatan Sebelum Diterapkannya Dekrit 43 Tahun 2006

3.2 Penerapan Dekrit 43 Tahun 2006 dan Dampaknya Bagi Layanan

Kesehatan .37

3.3 Analisis Teori Terkait Implementasi Dekrit 43 Tahun 2006.

4. KESIMPULAN

DAFTAR PUSTAKA .57 


\section{DAFTAR GRAFIK}

Grafik 1.1 Tingkat Inflasi Vietnam Tahun 1986-2006............................................ 1

Grafik 2.1 Perbedaan Pendapatan Antara Masyarakat Kaya dan Miskin di Vietnam.

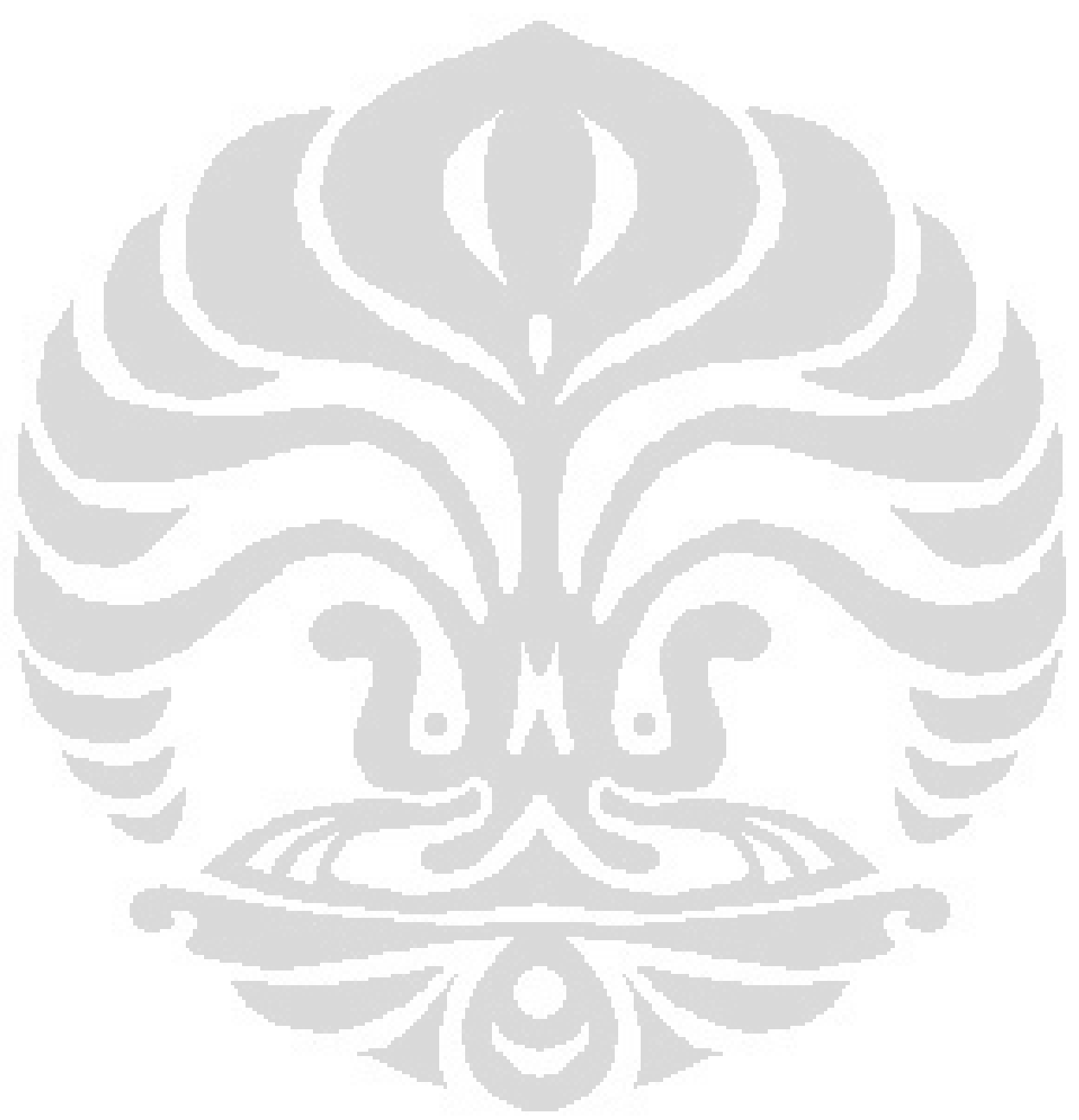




\section{DAFTAR TABEL}

Tabel 3.1 Perbandingan Dekrit 10 Tahun 2002 dan Dekrit 43 Tahun 2006. .38

Tabel 3.2 Tabel Out-of-pocket Berdasarkan Pembayaran Rumah Tangga. . .40

Tabel 3.3 Perbandingan Rumah Sakit dengan Otonomi Penuh dan Otonomi Parsial di Beberapa Wilayah. 41

Tabel 3.4 Jenis Perawatan Kesehatan Berdasarkan Durasi Sakit dan Pendapatan Rumah Tangga \% (Jumlah Tindakan) .44

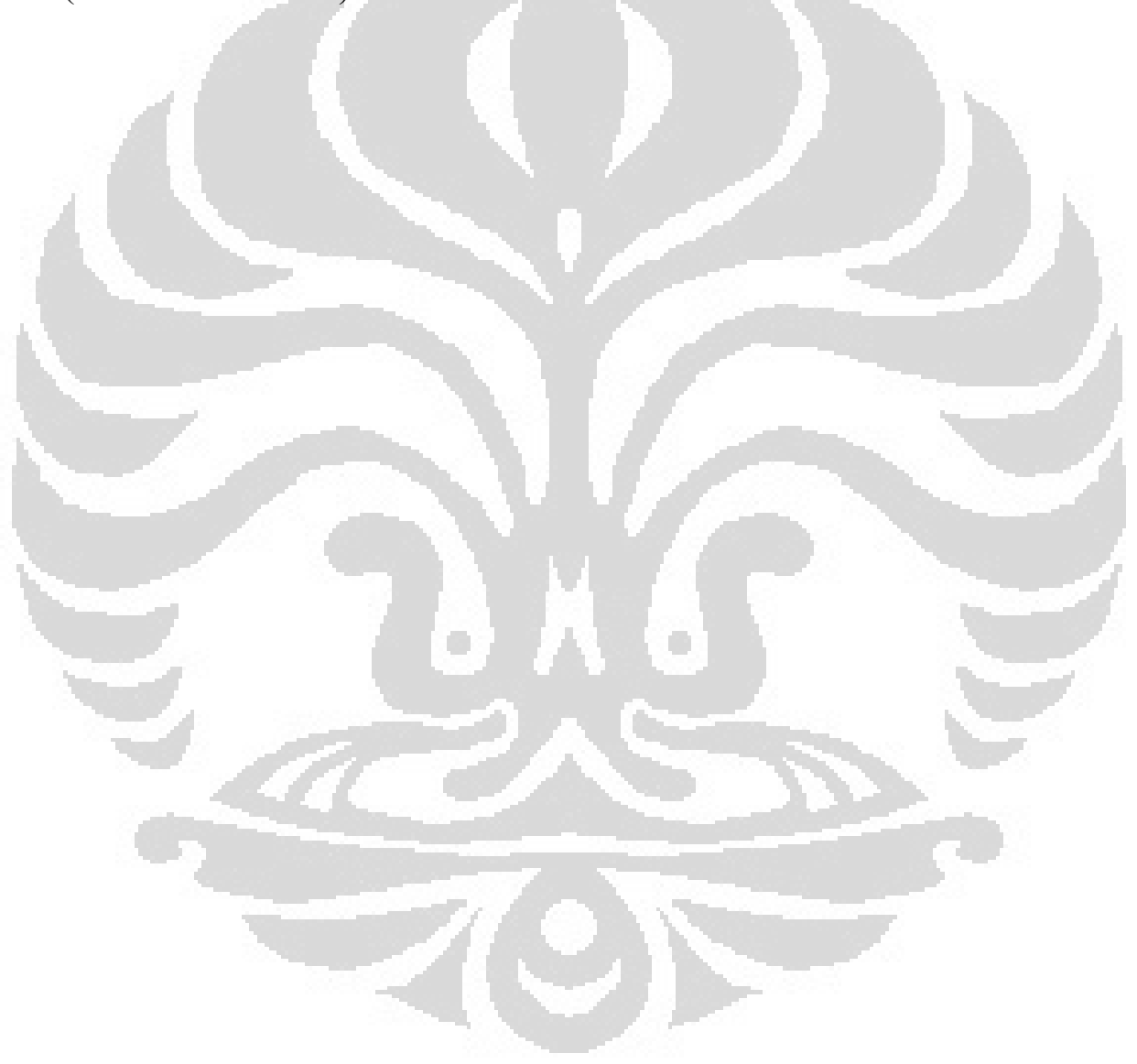




\section{DAFTAR SINGKATAN}

$\begin{array}{ll}\text { BUMN } & : \text { Badan Usaha Milik Negara } \\ \text { CHC } & : \text { Commune Health Centers } \\ \text { CHS } & : \text { Commune Health Station } \\ \text { FDI } & : \text { Foreign Direct Investment } \\ \text { FFS } & : \text { Fee For Service } \\ \text { HCFP } & : \text { Health Care Fund for the Poor } \\ \text { HEPR } & : \text { Hunger Eradication and Poverty Reduction } \\ \text { IDA } & : \text { International Development Assistance } \\ \text { ODA } & : \text { Official Development Assistance } \\ \text { OOP } & : \text { Out-of-pocket } \\ \text { PCOMs } & : \text { Partners for Change Outcome Management System } \\ \text { PDB } & : \text { Produk Domestik Bruto } \\ \text { PKV } & : \text { Partai Komunis Vietnam } \\ \text { PMA } & : \text { Penanaman Modal Asing } \\ \text { PRSP } & : \text { Poverty Reduction Strategy Paper } \\ \text { VCP } & : \text { Vietnam Communist Party } \\ \text { VSS } & : \text { Vietnam Social Security }\end{array}$




\section{BAB 1}

\section{PENDAHULUAN}

\subsection{Latar Belakang}

Doi Moi merupakan suatu kebijakan yang bertujuan membuka perekonomian Vietnam yang awalnya tertutup ${ }^{1}$. Sebelum adanya reformasi ekonomi Doi Moi, Vietnam yang menganut sistem ekonomi perencanaan mengalami inflasi mencapai lebih dari $700 \%^{2}$, seperti yang tergambar dalam grafik di bawah ini:

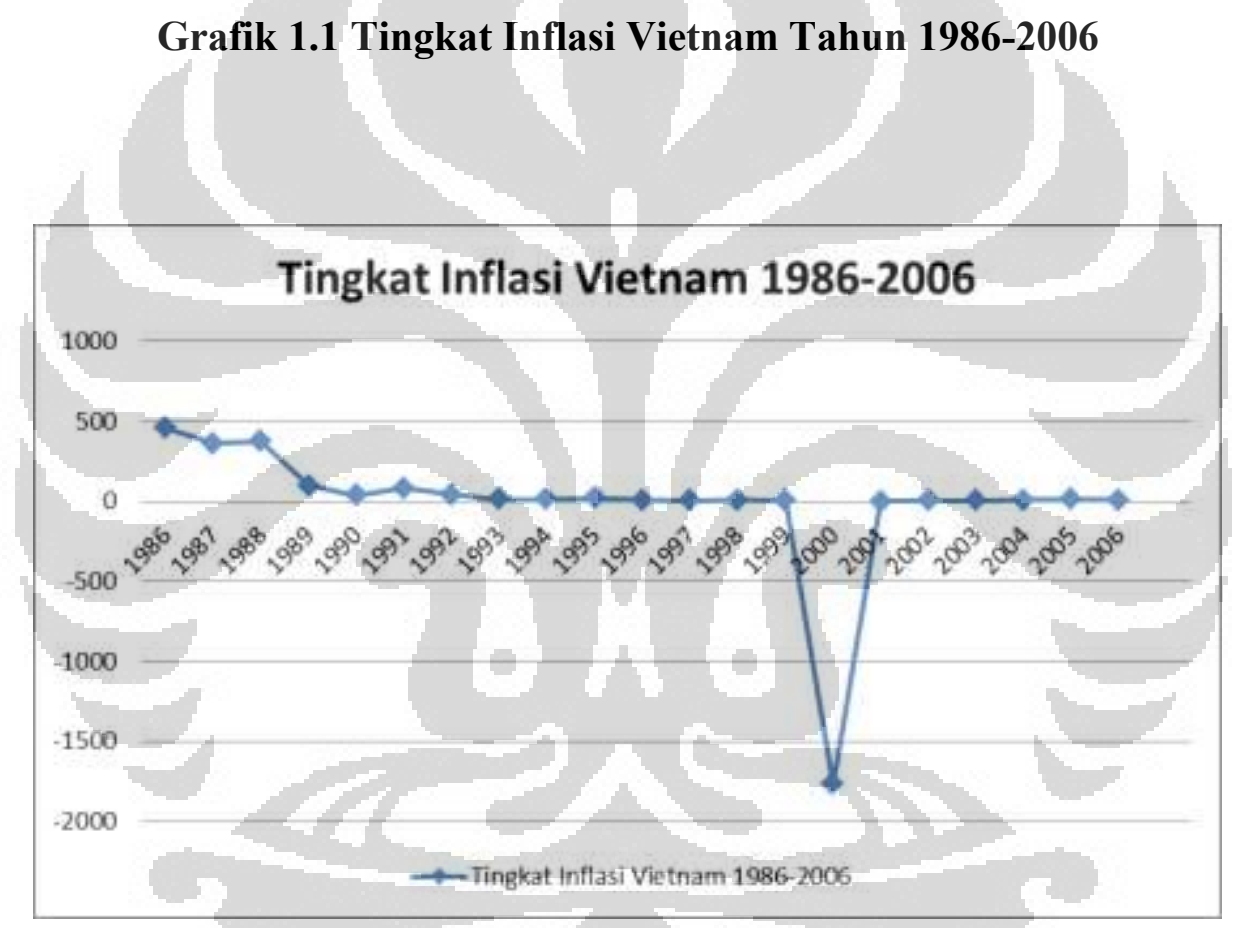

Sumber: International Monetary Fund, World Economic Outlook Database (Washington DC: International Monetary Fund, April 2015), hlm. 55.

Berdasarkan tabel di atas, dapat dilihat bahwa pada awalnya di tahun 1986, Vietnam mengalami kenaikan perekonomian. Namun, seiring dengan berjalannya waktu, kondisi ekonomi Vietnam mengalami penurunan yang cukup signifikan,

\footnotetext{
1 USA International Business Publications, Vietnam Recent Economic and Political Developments Yearbook, (Washington: Global Investment Center, 2008), hlm. 83-84.

2 Dion Hardika Sumarto, Skripsi Penelitian: Pembaruan Ekonomi (Doi Moi) di Vietnam 1986-1991 (Depok: Program Studi Ilmu Sejarah. Fakultas Ilmu Pengetahuan Budaya, Universitas Indonesia, 2007), hlm. 67.
} 
terutama pada tahun 1999-2001. Inflasi yang besar menyumbangkan penurunan pendapatan negara. Sehingga, masuknya investasi asing dan pihak swasta diharapkan dapat membantu kondisi finansial negara. Tetapi, hal tersebut berdampak kepada komersialisasi yang dilakukan oleh pihak swasta.

Adanya nilai impor yang lebih besar dibandingkan nilai ekspor yang dilakukan oleh negara membuat Vietnam membutuhkan suatu kebijakan yang dapat meningkatkan perekonomian negara. ${ }^{3}$ Berdasarkan kongres ke-6 Partai Komunis Vietnam (VCP) tahun 1986, Vietnam mulai mereformasi perekonomiannya. Namun sebelum diterapkannya kebijakan ekonomi Doi Moi, sempat terjadi perdebatan antara kelompok reformis dan kelompok konservatif. Kelompok reformis merupakan kelompok yang menginginkan perubahan ekonomi Vietnam, tokoh sentral dalam kelompok reformis adalah Nguyen Van Linh. Kelompok reformis menganggap sistem ekonomi sosialis yang sebelumnya diterapkan dinilai menjadi penyebab utama terjadinya krisis ekonomi karena terdapat pengendalian sistem ekonomi secara penuh yang dilakukan secara terpusat oleh negara sehingga membuat perekonomian tidak dapat berkembang. ${ }^{4}$

Sementara itu kelompok konservatif yang tokoh sentralnya adalah Truong Chinh tetap ingin mempertahankan sistem ekonomi Vietnam yang lama yaitu sistem ekonomi yang berpusat pada negara. Bagi kelompok konservatif, perubahan sistem ekonomi menjadi tidak sentralistik dapat mengancam disiplin sosialis dan kewibawaan partai karena rakyat atau pelaku ekonomi dapat melakukan hal yang tidak sesuai dengan garis yang ditentukan partai.

Sistem ekonomi sosialis Vietnam yang pernah dijalankan mengunakan sistem sentralistik sehingga kelompok reformis menekankan perlunya pembaharuan dalam perekonomian Vietnam. Selain itu, perdebatan antara kelompok konservatif dan kelompok reformis mengenai penerapan kebijakan Doi Moi melalui pemerintahan terpusat dianggap dapat memicu ketidakseimbangan pemerintahan dalam hal

\footnotetext{
${ }^{3}$ Brian van Arkadie dan Raymond Mallon, Vietnam: A Transition Tiger? (Canberra: Asia Pasific Press, 2004), hlm. 66-68.

${ }^{4}$ Alek Antariksa, "Peran Kepemimpinan Reformis Nguyen Van Linh (1986-1991) dalam Menciptakan Keberhasilan Pembaharuan Ekonomi Doi Moi di Vietnam”, (Fakultas Ilmu Sosial dan Ilmu Politik Universitas Indonesia, 1996). Hlm. 76-77.

${ }^{5}$ Ibid, hlm. 81 .
} 
kesejahteraan masyarakat. ${ }^{6}$ Kelompok konservatif menilai bahwa adanya reformasi di bidang ekonomi dianggap sebagai sebuah penyerangan terhadap landasan ideologi yang mereka miliki, yaitu ideologi komunisme. ${ }^{7}$ Hal ini dikarenakan reformasi yang dilakukan dapat mendukung kapitalisme yang ada dalam negara. Akan tetapi, kelompok reformis memiliki penilaian bahwa reformasi akan berdampak baik terhadap keadaan ekonomi negara. ${ }^{8}$

Tujuan lain dari Doi Moi adalah mengenalkan sistem ekonomi melalui berbagai macam sektor yang berfokus pada pelayanan publik melalui investasi pihak swasta. ${ }^{9}$ Perubahan tersebut mereformasi ekonomi Vietnam sehingga setelah Doi Moi diberlakukan, pemerintah tidak bekerja sendiri dalam menjalankan kebijakan perekonomian negara. Pemerintah Vietnam dibantu oleh sektor swasta yang bertindak sebagai pemberi modal bagi negara dalam pendanaan guna membangun perekonomian negara. Sikap keterbukaan pintu dalam liberalisasi perdagangan ini dilakukan secara bertahap dalam rangka untuk menstabilkan situasi sosial dan politik dan mencapai integrasi ekonomi.

Setelah dilaksanakannya kebijakan Doi Moi, sistem perekonomian Vietnam telah mengalami perubahan dari yang awalnya tertutup dan bersifat sentralistik menjadi terbuka dan berorientasi pada pasar. Investasi-investasi swasta ataupun investasi asing bebas untuk masuk dan diharapkan dapat menunjang ekonomi negara. Namun seiring berjalannya waktu, kebijakan Doi Moi menyebabkan berbagai sektor lebih komersial, tidak terkecuali pada sektor pelayanan publik. Pelayanan publik seperti pelayanan kesehatan menjadi timpang antara masyarakat kelas bawah dan masyarakat kelas atas. Hal ini juga didukung oleh pendapatan per kapita masyarakat Vietnam yang tidak merata sehingga menyebabkan kesenjangan ekonomi. ${ }^{10}$ Kebijakan Doi Moi yang bertujuan untuk menunjang perekonomian Vietnam dengan membuka diri terhadap

\footnotetext{
${ }^{6}$ Arkadie dan Mallon, Op. Cit, hlm. 66.

${ }^{7}$ Sujian Guo, Economic Transition in China and Vietnam: A Comparative Perspective. Asian Profile, Vol 32, No. 5, Oktober 2004, hlm. 394-410.

${ }^{8}$ Dion Hardika Sumarto, Op. Cit, hlm. 68.

9 Tran Thi Que \& To Xuan Phuci, "La Politique du Moi Doi et Son Impact sur Les Pauvres". Centre for Gender, Environment and Sustainable Development Studies, 2003, hlm. 1-6, diakses melalui http://www.socialwatch.org/sites/default/files/pdf/en/vietnam2003 fran.pdf pada 15 Oktober 2016 pukul 12.16 WIB.

${ }^{10}$ Tran Thi Que \& To Xuan Phuci, Ibid.
} 
investasi swasta pada akhirnya menyebabkan tidak meratanya perekonomian penduduk Vietnam.

\subsection{Rumusan Masalah}

Implementasi kebijakan Doi Moi pada awalnya telah menaikkan perekonomian Vietnam, tetapi hal tersebut tidak berlangsung lama karena peranan swasta dinilai hanya mencari keuntungan semata sehingga menimbulkan ketidakmerataan akses pelayanan sosial bagi masyarakat. Badan Usaha Milik Negara Vietnam pun semakin lama semakin terkikis oleh adanya badan usaha yang dimiliki oleh pihak asing dan pihak swasta. Berdasarkan latar belakang tersebut, di balik peningkatan ekonomi Vietnam yang cukup signifikan, masih terdapat beberapa hal yang penting untuk dikaji lebih dalam, yaitu seperti rendahnya pemerataan ekonomi antara masyarakat kaya dan miskin. Ketidakmerataan ekonomi Vietnam terlihat salah satunya pada bidang pelayanan sosial masyarakat. Penelitian ini berfokus pada salah satu pelayanan kesehatan, yang menjadi esensial dalam pelayanan sosial masyarakat.

Bidang kesehatan memiliki pengaruh yang cukup signifikan dalam implementasi kebijakan Doi Moi, karena kesehatan memiliki pengaruh terhadap taraf hidup masyarakat sehingga akan mempengaruhi pula peningkatan ekonomi yang didasarkan oleh kinerja masyarakat. Ketidakmerataan dalam bidang kesehatan terlihat dengan adanya data pada tahun 2003 yang melaporkan bahwa masyarakat menengah atas membayar 5\% dari pendapatan mereka untuk perawatan kesehatan, namun masyarakat menengah ke bawah membayar $8,4 \%$ untuk perawatan kesehatan. ${ }^{11}$ Hal ini disebabkan oleh tidak adanya pilihan bagi masyarakat menengah bawah untuk mengakses layanan kesehatan yang layak selain melakukan pengobatan di klinik swasta. Permasalahan ketidakmerataan terhadap pelayanan kesehatan adalah dengan diperkenalkannya sistem fee for service yaitu keharusan membayar untuk mendapatkan pelayanan kesehatan, serta sistem asuransi kesehatan yang hanya dapat diakses oleh kalangan tertentu. Untuk

\footnotetext{
${ }^{11}$ Le Thanh Forsberg, The Political Economy of Health Care Reform in Vietnam. Princeton Global Leaders Fellow Woodrow Wilson School of Public and International Affairs Princeton University, 2010 (diakses melalui https://www.princeton.edu/ $\sim$ pcglobal/conferences/GLF/forsberg_glf.pdf pada tanggal 25 September 2017 pukul 15.34 WIB), hlm. 13.
} 
menciptakan pemerataan layanan kesehatan, maka pemerintah berupaya membuat beberapa peraturan terkait layanan kesehatan, salah satunya melalui Dekrit 43 Tahun 2006.

\subsection{Pertanyaan Penelitian}

Berdasarkan rumusan masalah di atas, maka pertanyaan penelitian tugas akhir ini adalah

"Apakah dampak yang terjadi pada bidang pelayanan kesehatan dalam penerapan kebijakan Doi Moi di Vietnam melalui implementasi Dekrit 43 Tahun 2006?

\subsection{Tujuan Penelitian dan signifikansi}

Penelitian ini bertujuan untuk menjelaskan bagaimana penerapan kebijakan ekonomi Doi Moi sehingga dapat menyebabkan adanya ketimpangan pelayanan kesehatan antara masyarakat kaya dan masyarakat miskin di Vietnam. Mengkaji kebijakan publik menjadi hal yang penting karena tujuan kebijakan tersebut dapat memberikan kehidupan yang lebih baik bagi masyarakat.

Penelitian ini penting untuk diteliti karena mencakup informasi mengenai proses berjalannya suatu tahapan kebijakan sehingga dapat memberikan pengaruh dalam berbagai bidang. Penelitian ini dimaksudkan untuk mengelaborasikan faktor-faktor yang menyebabkan tidak meratanya pelayanan kesehatan pada masyarakat Vietnam. Dengan adanya penelitian ini, diharapkan dampak kebijakan Doi Moi terhadap pelayanan kesehatan dapat dijelaskan secara rinci dan memberikan manfaat bagi masyarakat.

\subsection{Tinjauan Pustaka}

Dalam menuliskan penelitian mengenai dampak dari adanya kebijakan ekonomi Doi Moi yang dibuat di negara Vietnam penulis terlebih dahulu telah melakukan studi literatur yang berasal dari buku, jurnal maupun artikel lain yang memiliki hubungan 
dengan penelitian yang dilakukan. Artikel yang berjudul "La politique du Moi Doi et Son Impact sur Les Pauvres" menjelaskan bahwa dalam pelaksanaan kebijakan Doi Moi, tingkat ekonomi yang dimiliki oleh seseorang akan berpengaruh terhadap pelayanan publik yang akan ia dapatkan. ${ }^{12}$ Jika seseorang memiliki penghasilan yang tinggi, maka pelayanan kesehatan yang didapatkan tentu akan lebih baik dibandingkan pelayanan kesehatan yang didapatkan oleh masyarakat yang berpenghasilan rendah. Kesehatan merupakan salah satu permasalahan sosial yang memiliki nilai penting, dan masyarakat di setiap negara tentunya membutuhkan kesehatan dan akses yang memadai. ${ }^{13}$

Pada kenyataannya tidak semua orang memiliki penghasilan yang tinggi sehingga hal ini merupakan salah satu hal yang sebaiknya menjadi fokus kajian pemerintah untuk menerapkan kebijakan yang mengatur mengenai pelayanan fasilitas kesehatan berdasarkan dengan keadaan ekonomi masyarakat. Masyarakat yang memiliki kondisi kesehatan yang buruk akan mengurangi produktivitas dan mendapatkan biaya tak terduga untuk layanan kesehatan.

Selain itu, kurangnya sumber daya yang berfungsi sebagai pendukung adanya pelayanan sosial membuat sektor kesehatan atau pelayanan publik rentan terhadap pasar komersial, padahal keberdayaan sumber daya dibutuhkan untuk didistribusikan dalam hal meningkatkan taraf hidup masyarakat di seluruh wilayah Vietnam, terutama bagi masyarakat miskin dan berada di daerah terpencil yang jauh dari perkotaan. ${ }^{14}$ Penelitian yang dilakukan oleh BioMed Central menyatakan bahwa layanan akses yang didapatkan oleh masyarakat bergantung pada tingkat penghasilan masyarakat itu sendiri. ${ }^{15}$ Berdasarkan studi literatur, masuknya investasi swasta dalam pendistribusian layanan kesehatan yang dilakukan oleh pihak swasta dengan pendirian beberapa klinik milik swasta dan beberapa pengendalian rumah sakit dipegang oleh pihak swasta seperti misalnya pada tingkat layanan kesehatan tertentu memicu tidak meratanya layanan

\footnotetext{
12 Thi Que, Tran and To Xuan Phuci, Loc.Cit, hlm. 1-6.

${ }^{13}$ Nguyen Xuan Thanh, dkk, The Impact of Economic Growth on Health Care Utilization: A Longitudinal Study in Rural Vietnam. The Official Journal of the International Society for Equity in Health, 2013, diakses melalui https://equityhealthj.biomedcentral.com/articles/10.1186/1475-9276-12-19 pada 16 Oktober 2016 pukul 10.41 WIB.

${ }^{14}$ Le Thanh Forsberg, Op. Cit. hlm. 1-33.

${ }^{15}$ Nguyen Xuan Thanh, Loc. Cit
}

Universitas Indonesia 
kesehatan yang diberikan karena pihak swasta cenderung menekankan unsur komersial pada layanan publik.

Laporan penelitian yang ditulis oleh Le Thanh Forsberg dengan judul The Political Economy of Health Care Reform in Vietnam menyatakan bahwa sektor kesehatan memiliki fokus pada komersialisasi layanan yang diberikan akibat reformasi Doi Moi tahun 1986. Karena memiliki keterbatasan dana, maka layanan kesehatan mendorong investasi swasta pada rumah sakit umum, sehingga tujuan pemerintah atas sistem perawatan kesehatan yang adil, efisien dan berkembang sulit tercapai. Komersialisasi layanan tidak hanya dilakukan secara individual oleh pihak swasta, namun juga oleh perusahaan-perusahaan farmasi, staf medis dan manajer rumah sakit. Hal ini menyebabkan layanan kesehatan sulit diakses oleh kelompok yang berpenghasilan rendah, terlebih ketika layanan medis dibuka untuk investasi sehingga hanya orang-orang yang berpenghasilan tinggi yang dapat menggunakan layanan kesehatan tersebut. ${ }^{16}$ Tulisan ini membantu dalam memahami alasan utama mengapa pelayanan kesehatan di Vietnam tidak merata. Perbedaan dengan penelitian ini adalah penelitian ini memfokuskan pada Dekrit 43 Tahun 2006 yang dampaknya masih ada hingga saat ini.

Tulisan lainnya yang menganalisis dampak yang terjadi akibat penerapan kebijakan Doi Moi adalah yang ditulis oleh Adam Wagstaff dan Nga Nguyet Nguyen. Doi Moi merupakan reformasi kebijakan yang bertujuan untuk memajukan perekonomian negara melalui orientasi pasar dengan cara membuka pintu perdagangan internasional, investasi dan pembangunan asing. Dalam tulisan yang berjudul Poverty and Survival Prospects of Vietnamese Children Under Doi Moi, pada awalnya dampak dari kebijakan Doi Moi berjalan sesuai harapan, dimana terjadi peningkatan ekonomi, yaitu $5-10 \%$ pertahun dan juga berkurangnya tingkat kemiskinan, tetapi sayangnya hal tersebut berbanding terbalik dengan perkembangan kualitas layanan kesehatan masyarakat yang akan berdampak terhadap masyarakat miskin. Berdasarkan standar internasional, dan pendapatan per kapita yang relatif rendah, Vietnam telah mencapai penurunan yang substansial dalam tingkat kematian, bayi dan balita. Pemerintah Vietnam memiliki tujuan untuk mengurangi angka kematian bayi menjadi 30\% di

\footnotetext{
${ }^{16}$ Le Thanh Forsberg, Op. Cit., hlm. 31-32.
} 
tahun 2000, sehingga Vietnam berupaya untuk mendapatkan bantuan berkelanjutan melalui Asosiasi Pembangunan Internasional (IDA) dengan cara menuliskan makalah strategi pengentasan kemiskinan (PRSP). ${ }^{17}$ Tulisan ini membantu penulis dalam memahami perubahan apa yang diakibatkan oleh Doi Moi dalam bidang kesehatan, terutama pada usaha peningkatan kesehatan rakyat miskin. Perbedaan laporan penelitian ini terletak pada fokus dampak kegagalan Doi Moi pada sektor kesehatan yaitu tingkat kematian anak-anak di Vietnam

Selain ketiga tulisan diatas, digunakan juga skripsi berjudul Pembaruan Ekonomi (Doi Moi) di Vietnam, 1986-1991 yang ditulis oleh Dion Hardika Sumarto untuk menjadi referensi bagi penulis. Tulisan Dion dapat membantu memahami kebijakan Doi Moi secara menyeluruh karena Dion menuliskan mengenai bagaimana kebijakan Doi Moi bisa tercipta dan pada akhirnya menyebabkan dampak tertentu. Walaupun Doi Moi merupakan kebijakan reformasi ekonomi, namun Doi Moi dapat mempengaruhi banyak sektor di Vietnam, seperti agrikultur dan kesehatan. Perbedaan skripsi Dion dengan tugas akhir ini adalah fokus Dion yang membahas mengenai pengaruh Doi Moi dibidang agrikultur. Dion hanya menuliskan sekilas bahwa Doi Moi memiliki pengaruh dibidang kesehatan. Lalu, dalam skripsi yang dituliskan oleh Dion menekankan pada dampak positif yang dihasilkan oleh kebijakan Doi Moi seperti naiknya pendapatan perkapita masyarakat Vietnam.

\subsection{Teori/Konsep}

\subsubsection{Konsep Kebijakan Publik}

Konsep yang digunakan oleh penulis untuk menjelaskan dampak dari reformasi ekonomi Vietnam adalah konsep kebijakan publik yang dikemukakan oleh Leslie A. Pal, dimana kebijakan publik memiliki dua kategori definisi, yang pertama berkaitan dengan maksud dan tujuan kebijakan, lalu yang kedua berkaitan dengan dampak dari tindakan pemerintah (dampak dari kebijakan pemerintah). Dalam penulisan ini

\footnotetext{
${ }^{17}$ Adam Wagstaff \& Nga Nguyet Nguyen. Poverty and Health Sector Inequalities. Bulletin of the World Health Organization, 2002, diakses melalui https://www.scielosp.org/pdf/bwho/v80n2/a04v80n2.pdf pada tanggal 17 Desember 2017 pukul 20.05 WIB, hlm. 2-3.
} 
kebijakan Doi Moi yang dilakukan oleh pemerintah memiliki dampak di bidang kesehatan dimana dampak tersebut menyebabkan ketidakmerataan layanan fasilitas kesehatan yang didapatkan masyarakat miskin. Berdasarkan hal tersebut maka definisi kebijakan publik yang lebih tepat untuk digunakan adalah yang berkaitan dengan dampak dari tindakan pemerintah. Menurut Leslie A. Pal dalam Widodo, kebijakan publik merupakan tindakan yang dilakukan oleh pemerintah dan mengapa hal tersebut dapat dilakukan untuk mengatasi permasalahan tertentu. ${ }^{18}$

Ditinjau dari definisi tersebut maka ketika pemerintah menerapkan suatu program kebijakan yang dalam penulisan ini adalah kebijakan Doi Moi, maka pemerintah mengharapkan akan ada timbal balik dari adanya pelaksanaan kebijakan tersebut, yaitu peningkatan ekonomi Vietnam. Kebijakan ekonomi Doi Moi bukan saja bertujuan agar ekonomi Vietnam naik, tetapi pemerintah juga dapat melihat dampakdampak apa saja yang akan ditimbulkan dari adanya peningkatan ekonomi Vietnam. Definisi ini memiliki keterkaitan dengan permasalahan yang akan diteliti. Karena definisi kebijakan publik yang dikemukakan berbicara mengenai dampak program yang memiliki tujuan yang berasal dari pemerintah. Dalam suatu pelaksanaan kebijakan publik, pembuat kebijakan harus memahami apakah kebijakan tersebut tercapai dan alasan apa yang menyebabkan kebijakan tersebut berhasil atau gagal. Lalu tujuan dari adanya penulisan ini adalah agar penulis dapat mencoba mengevaluasi dan melihat hal apa saja yang mendorong kegagalan/keberhasilan dari adanya kebijakan ekonomi tersebut.

Adanya permasalahan ekonomi di Vietnam membuat hal tersebut menjadi isu yang menarik untuk dijadikan agenda kebijakan publik, menurut Dunn seperti pendapat Kimber, Salesbury, Sandbach, serta Hogwood dan Gunn, terdapat enam hal yang menjadi penyebab suatu masalah dapat dijadikan agenda publik yang kemudian pelaksanaannya akan dilanjutkan oleh pemerintah, namun terkait dengan kebijakan ekonomi yang diberlakukan di negara Vietnam, penulis mengambil tiga hal yang dianggap penting yaitu suatu permasalahan dapat dijadikan agenda publik apabila:

\footnotetext{
${ }^{18}$ Joko Widodo, Analisis Kebijakan Publik, Sidoarjo: Bayumedia Publishing, 2006, hlm. 10-17.
} 
Satu, mencapai titik krisis tertentu, jika diabaikan, akan menjadi ancaman yang serius, Dua, menjangkau dampak yang sangat luas, dan Tiga, menyangkut emosi tertentu dari sudut kepentingan orang banyak. ${ }^{19}$

Merujuk kepada permasalahan yang terjadi di Vietnam, kebijakan Doi Moi yang ditetapkan pelaksanaannya setelah kongres ke-6 Partai Komunis Vietnam perlu dilaksanakan. Mengapa demikian? Pada poin-poin di atas tertulis bahwa suatu permasalahan dianggap penting untuk dijadikan agenda publik karena menjangkau dampak yang sangat luas. Hal ini tentu memiliki keterkaitan dengan dampak yang akan dijelaskan oleh penulis akibat pelaksanaan kebijakan Doi Moi yang tidak sempurna. Sehingga konsep di atas dianggap tepat untuk dapat menjelaskan pentingnya pelaksanaan kebijakan Doi Moi.

\subsubsection{Teori Implementasi Kebijakan}

Penelitian ini menggunakan teori implementasi kebijakan yang dikemukakan oleh Daniel A. Mazmanian dan Paul A. Sabatier. Dalam keberhasilan suatu implementasi, dibutuhkan 3 variabel, yaitu karakteristik masalah, karakteristik kebijakan/undang-undang dan variabel lingkungan. ${ }^{20}$ Karakteristik masalah mencakup empat hal, di antaranya tingkat kesulitan teknis masalah, tingkat kemajemukan kelompok sasaran, proporsi kelompok sasaran terhadap total populasi dan cakupan perubahan perilaku yang diharapkan. ${ }^{21}$ Lalu, karakteristik kebijakan mencakup kejelasan isi kebijakan, dukungan teoritis kebijakan, besarnya sumber daya finansial untuk kebijakan, keterpautan dan dukungan dari institusi pelaksana, kejelasan dan konsistensi aturan pada badan pelaksana, tingkat komitmen aparat terhadap tujuan kebijakan dan akses kelompok luar untuk berpartisipasi dalam implementasi kebijakan. Sedangkan, dalam lingkungan kebijakan mencakup kondisi sosial ekonomi masyarakat dan tingkat kemajuan teknologi, dukungan pemerintah dalam suatu kebijakan, sikap kelompok pemilih serta tingkat komitmen serta keterampilan aparat dan implementor. ${ }^{22}$

\footnotetext{
${ }^{19}$ Herabudin, Studi Kebijakan Pemerintah Dari Filosofi ke Implementasi (Bandung: CV Pustaka Setia, 2016), hlm. 60.

${ }^{20}$ Ibid., hlm. 139.

${ }^{21}$ Ibid., hlm. 140.

${ }^{22}$ Ibid., hlm. 140-141.
} 
Teori ini digunakan untuk mengidentifikasi permasalahan dalam implementasi kebijakan Doi Moi yang menyebabkan sejumlah dampak negatif, salah satunya adalah ketidakmerataan pada pelayanan kesehatan. Penelitian ini akan menjelaskan karakteristik kebijakan dan karakteristik masalah sesuai dengan variabel yang disebutkan oleh Mazmanian dan Sabatier, yang pada akhirnya akan memperlihatkan sejauh mana kebijakan Doi Moi dianggap berhasil dalam meningkatkan taraf hidup masyarakat Vietnam.

\subsubsection{Konsep Pelayanan Publik}

Pelayanan publik menurut KBBI adalah kemudahan yang diberikan dalam hal barang dan jasa. Inu Kencana Syafi'ie menyatakan pelayanan publik sebagai 'Sejumlah manusia yang memiliki kebersamaan berfikir, perasaan, harapan, sikap dan tindakan yang benar dan baik berdasarkan nilai- nilai norma yang mereka miliki". ${ }^{23}$ Pelayanan publik memiliki dua sifat yaitu komersial dan non-komersial, biasanya pelayanan publik yang bersifat komersial dilaksanakan oleh pihak swasta dan pelayanan publik nonkomersial dilaksanakan oleh pemerintah. ${ }^{24}$ Pada pelaksanaannya, pelayanan publik dilakukan berdasarkan ketetapan undang-undang yang berlaku. Konsep pelayanan publik digunakan untuk menjelaskan definisi pelayanan publik yang disebutkan dalam penelitian ini, hal ini bertujuan agar dapat memahami makna pelayanan publik sehingga dapat lebih mudah dipahami oleh pembaca.

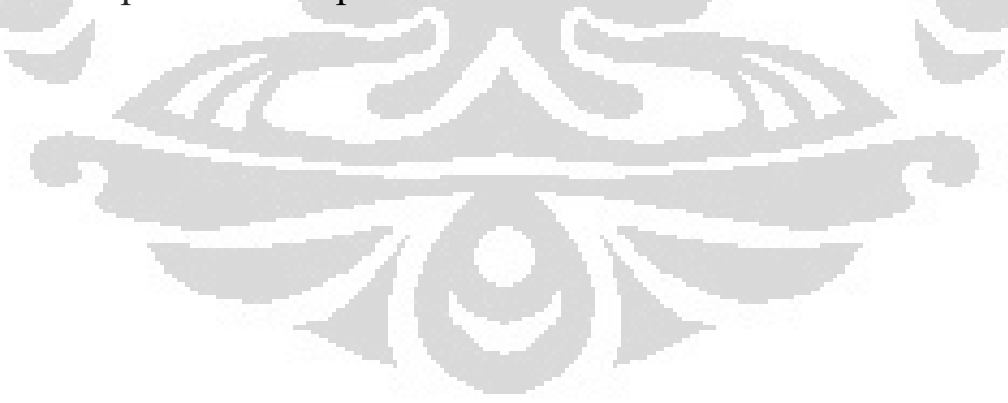

\footnotetext{
${ }^{23}$ Pangesti Febri Galih, Skripsi Penelitian: Pelaksanaan Pelayanan Publik di Puskesmas Ngalik 1 Sleman Yogyakarta (Yogyakarta: Universitas Negeri Yogyakarta, 2012), hlm. 11.

${ }^{24}$ Ibid., hlm. 11-12.
} 


\subsection{Skema Alur Berpikir}

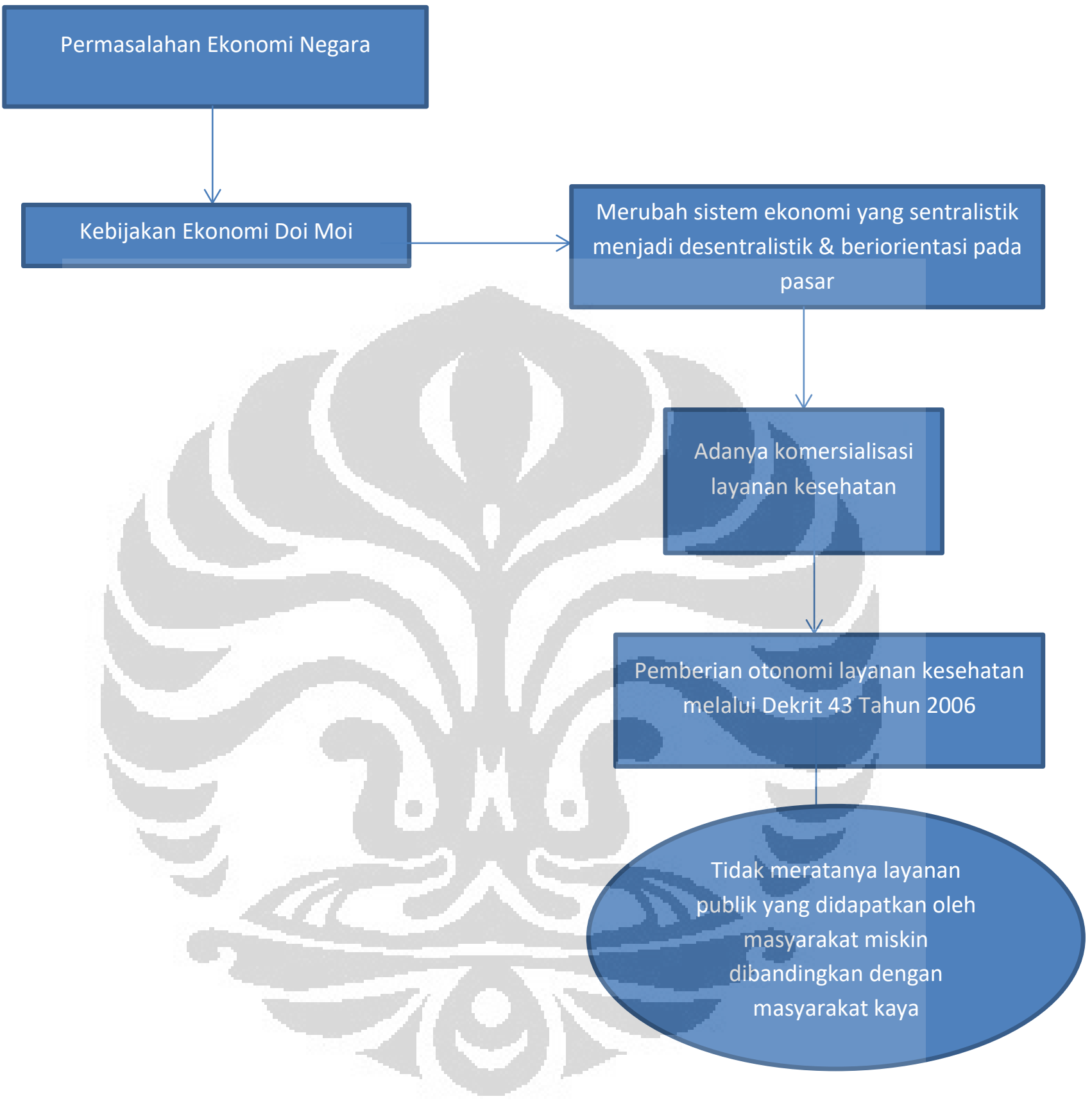

Doi Moi merupakan kebijakan yang bertujuan untuk membuka perekonomian Vietnam yang awalnya tertutup melalui investasi swasta dan pihak asing. Tetapi, hal ini tetap mendapatkan pengawasan dari negara dengan cara dibuatnya undang-undang yang mengatur khusus mengenai hal tersebut. Doi Moi dibuat berdasarkan kongres Partai Komunis Vietnam atau Vietnam Communist Party (VCP) ke-6 yang dilaksanakan pada tahun 1986. Sebelum Doi Moi diberlakukan, perekonomian di Vietnam menggunakan 
sistem sentralistik yang sesuai dengan ideologi komunisme Vietnam. Sistem ekonomi Doi Moi yang baru menyebabkan komersialisme layanan kesehatan di Vietnam, sehingga hal ini mendorong pemerintah untuk mengeluarkan aturan terkait penyediaan layanan kesehatan, salah satunya melalui Dekrit 43 Tahun 2006 yang dimana dekrit tersebut berisikan pemberian otonomi dari pemerintah pada penyedia layanan kesehatan (rumah sakit).

Kebijakan Doi Moi yang digagas oleh Nguyen Van Linh memiliki tujuan yang baik, tetapi dalam menerapkan suatu kebijakan diperlukan kerja sama tidak hanya dari pengagasan kebijakan tersebut, namun juga diperlukan kerja sama dari pihak yang turut andil dalam pembuatan kebijakan. Dalam hal ini, pihak swasta menjadi investor bagi pembangunan ekonomi. Harapan masuknya investasi dari luar negara agar dapat terciptanya peningkatan ekonomi yang akan berdampak pula pada kesejahteraan masyarakat. Seiring dengan diterapkannya kebijakan Doi Moi, terdapat komersialisasi layanan publik oleh pihak swasta, hal ini membuat implementasi Doi Moi tidak berjalan sesuai dengan yang seharusnya.

\subsection{Metode penelitian}

Penelitian ini menggunakan metode kualitatif untuk menjelaskan dampak pelayanan kesehatan yang disebabkan oleh kebijakan Doi Moi di Vietnam. Penelitian ini menggunakan beberapa macam metode pengumpulan data. Terdapat tiga tahapan dalam metode pengumpulan data, yaitu teknik pengumpulan data, teknik analisis data, dan instrumen pengolahan data.

\subsubsection{Teknik Pengumpulan Data}

Informasi untuk menjawab pertanyaan penelitian diperoleh melalui studi literatur dan dokumen. Studi tersebut dilakukan dengan cara mempelajari buku, jurnal, artikel, dan dokumen pemerintahan yang berkenaan dengan dampak kebijakan Doi Moi dalam bidang pelayanan kesehatan.

\subsubsection{Teknik Analisis Data}

Setelah teknik pengumpulan data dilakukan, analisis secara mendalam akan dilakukan. Hasil tulisan yang dikumpulkan akan dimaknai lebih detail, guna 
mempelajari data-data yang didapatkan mengenai dampak kebijakan Doi Moi pada bidang pelayanan kesehatan. Teknik analisis data akan diakhiri dengan interpretasi data terhadap data-data yang telah didapatkan sebelumnya.

\subsubsection{Instrumen Pengumpulan Data}

Hasil data yang diperolah akan dilampirkan bersamaan dengan penelitian ini. Data yang didapatkan akan dimasukkan sebagai lampiran buku, jurnal, atau dokumen pemerintahan.

\subsection{Sistematika penelitian}

Bab 1 Pendahuluan. Bab ini akan menjelaskan abstrak, latar belakang, rumusan masalah, pertanyaan penelitian, tujuan dan signifikansinya dalam ilmu politik, tinjauan pustaka, kerangka teori yang digunakan untuk menganalisa permasalahan tersebut, metode penelitian yang dilakukan, dan skema alur berpikir terhadap permasalahan penelitian. Latar belakang mencakup tujuan pelaksanaan kebijakan Doi Moi serta penjelasan singkat mengenai dampak yang ditimbulkan dari penerapan kebijakan.

\section{Bab 2 Reformasi Kebijakan Doi Moi dan Komersialisasi Layanan} Kesehatan Pasca Doi Moi . Bab ini akan menjelaskan bagaimana kebijakan Doi Moi dapat terlaksana, lalu akan dijelaskan mengenai dampak yang terjadi akibat penerapan kebijakan tersebut seperti komersialisasi layanan kesehatan. Pada bab ini akan dijelaskan secara lengkap bagaimana terjadinya komersialisasi layanan kesehatan dan apa sajakah solusi yang diberikan oleh pemerintah untuk mengatasi permasalahan tersebut.

Bab 3 Implementasi Dekrit 43 Tahun 2006 Terhadap Layanan Kesehatan. Bab ini akan membahas mengenai aturan yang dibuat oleh pemerintah agar masyarakat miskin dapat mengakses layanan kesehatan sesuai dengan kebutuhan mereka tanpa harus mengeluarkan biaya yang besar. Pada bab ini akan dibahas mengenai tujuan Dekrit 43 Tahun 2006 serta dampak yang ditimbulkan dari adanya dekrit tersebut melalui analisis teori implementasi kebijakan. 
Bab 4 Kesimpulan. Bab ini akan menguraikan kesimpulan penelitian dan lampiran penelitian berdasarkan pembahasan dalam bab sebelumnya berdasarkan data yang diperoleh.

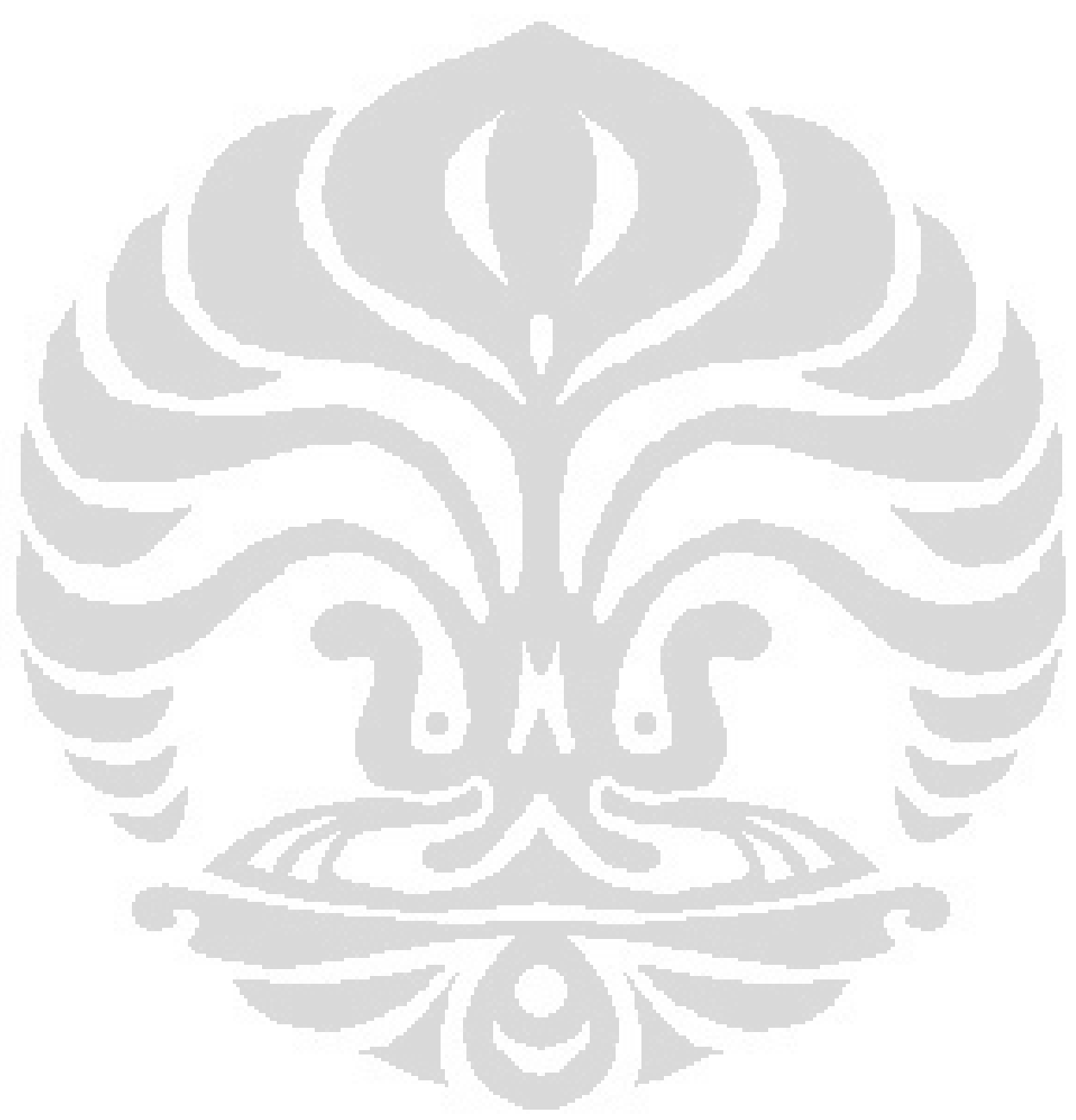




\section{BAB 2}

\section{REFORMASI KEBIJAKAN DOI MOI DAN KOMERSIALISASI LAYANAN KESEHATAN PASCA DOI MOI}

Berjalannya reformasi ekonomi Doi Moi memiliki berbagai macam dampak positif maupun negatif. Pada bab sebelumnya, telah dituliskan mengenai dampak negatif Doi Moi yaitu menyebabkan ketidakmerataan akses layanan kesehatan antara masyarakat kaya dan masyarakat yang miskin. Hal tersebut dikarenakan adanya investasi asing dan swasta yang pada akhirnya memberikan peluang kepada pihak-pihak tersebut untuk ikut andil dalam pelaksanaan kebijakan ini. Layanan kesehatan yang berpusat di perkotaan dinilai diperuntukan untuk masyarakat yang memiliki dana lebih untuk membayar. Beberapa artikel yang menjadi tinjauan pustaka pada bab 1 juga telah menyebutkan bahwa layanan kesehatan yang didapatkan oleh masyarakat tergantung pada keuangan yang mereka miliki. Jika mereka memiliki dana yang besar untuk dibayarkan pada layanan kesehatan, maka mereka akan mendapatkan prioritas pelayanan kesehatan. Sementara itu bagi masyarakat miskin yang memiliki dana terbatas, akan lebih sulit untuk mendapatkan layanan kesehatan sesuai dengan apa yang mereka butuhkan. Cukup banyak prosedur yang harus mereka jalani agar mendapatkan layanan kesehatan yang sama dengan masyarakat kaya.

Pada bab ini, akan dijabarkan mengenai reformasi ekonomi Doi Moi, dimana akan dibahas mengenai proses keterlibatan pihak asing dan swasta dalam pelaksanaan kebijakan ini. Selain itu, bab ini akan membahas secara lebih detail mengenai ketidakmerataan yang disebabkan oleh penerapan kebijakan Doi Moi dimana dampak negatif yang ditimbulkan didasarkan kepada implementasi kebijakan yang salah. Pihakpihak yang terlibat dalam pelaksanaan kebijakan tidak 100\% menjalankan kebijakan sesuai dengan tujuannya. Contohnya adalah adanya komersialisasi yang ditimbulkan dari adanya layanan kesehatan. Hal ini merupakan salah satu dampak yang terjadi akibat dari implementasi kebijakan yang salah, padahal pemerintah telah memberikan dana bagi layanan kesehatan. Mengapa hal tersebut masih belum dapat terpenuhi untuk akses layanan kesehatan? Penulisan pada bab ini bertujuan untuk mengetahui penyebab dari adanya ketidakmerataan layanan kesehatan, selain itu dalam menyelesaikan permasalahan terkait layanan kesehatan, pemerintah telah menerapkan beberapa 
kebijakan agar layanan kesehatan dapat menjangkau masyarakat miskin sehingga diharapkan dapat mempermudah masyarakat miskin untuk mendapatkan layanan yang sama.

\subsection{Reformasi Kebijakan Doi Moi}

Pada tahun 1954, Vietnam memiliki dua sistem ekonomi yang berbeda. Vietnam Selatan (Republik Vietnam) menganut sistem ekonomi liberal, sementara Vietnam Utara (Republik Demokratik Vietnam)_menganut sistem ekonomi sentralistik. Bersatunya Vietnam pada tahun 1976 membuat negara dihadapkan pada berbagai permasalahan seperti permasalah ekonomi, yaitu sulitnya pertumbuhan ekonomi, adanya ketidakseimbangan pembayaran, hiperinflasi dan peningkatan utang. Dalam kongres ke-4 VCP/PKV terjadi kesepakatan dimana perekonomian sebaiknya bergerak dari produksi skala kecil menuju produksi skala besar tanpa kapitalisme, sehingga prioritas ditujukan kepada industri berat dan mengubah Vietnam menjadi negara sosialis dengan orientasi pada bidang pertanian dan industri modern. Tetapi, produksi pangan mengalami kegagalan lebih dari 30\% pada tahun 1980, hal ini menyebabkan perekonomian Vietnam semakin menurun. ${ }^{25}$

Selain dalam hal pertanian, di akhir 1980, Vietnam juga mengalami krisis yang berasal dari kurangnya investasi dan buruknya sistem keorganisasian dalam pemerintahan Vietnam. Permasalahan ini menyebabkan sektor sosial tidak memiliki kerangka hukum yang jelas dan menyebabkan hilangnya subsidi dana pemerintah. Permasalahan yang terjadi tersebut menyebabkan adanya dorongan perubahan sistem ekonomi untuk meningkatkan perekonomian Vietnam. Pada tahun 1986, kongres yang dilakukan PKV memutuskan bahwa Doi Moi dilaksanakan dengan membuka sistem perekonomian Vietnam. Setelah pelaksanaan kebijakan Doi Moi, perlahan-lahan perekonomian Vietnam menjadi membaik. ${ }^{26}$

\footnotetext{
${ }^{25}$ Bao Pham. The Economic Reform in Vietnam in 1989: "Shock Therapy or Gradualism?". (San Diego: University of California), diakses melalui http://econweb.ucsd.edu/ rstarr/191AB\%20Fall\%202016\%20Winter\%202017/ExemplaryPapers2016/Ec onomic\%20Reform\%20in\%20Vietnam.pdf pada tanggal 17 Desember 2017 pukul 20.38 WIB.

${ }^{26}$ Scott Fritzen, Growth, Inequality, and The Future of Poverty Reduction in Vietnam, Journal of Asian Economics 13, National University of Singapore, 2002, (diakses melalui https://wagner.nyu.edu/files/faculty/publications/SFritzen_GrowthInequalityAndTheFuture.pdf pada tanggal 17 Desember 2017 pukul 20.52 WIB), hlm. 642.
}

\section{Universitas Indonesia}


Namun, hal tersebut tidak bertahan lama, karena pada tahun 1999-2001 terjadi permasalahan Krisis Asia 1997-1998 yang berdampak yang kurang baik bagi negaranegara didalamnya. Pada akhir 1990 dan awal 2000, Vietnam merasakan dampak dari krisis yang terjadi di Asia dimana perekonomian menurun dan permintaan domestik serta internasional untuk barang produksi Vietnam juga menurun. Meskipun terjadi peningkatan uang dan kredit (30-40\% per tahun) dan devaluasi VND yang besar (sekitar $36 \%$ ) selama tahun 1997-2003, namun inflasi masih terjadi di Vietnam. ${ }^{27}$

Kebijakan Doi Moi digagas oleh Nguyen Van Linh pada saat Kongres Partai Komunis Vietnam yang ke-6, hal ini dikarenakan pada kebijakan New Economic Reform tahun 1979 dan Economic Reform tahun 1985 yang telah diterapkan sebelumnya tidak meningkatkan perekonomian Vietnam sesuai harapan. Sebelum ditetapkannya kebijakan Doi Moi pada tahun 1986, Vietnam merupakan negara yang memiliki sistem ekonomi sosialis atau tertutup. Sistem perekonomian yang tertutup membuat pemerintah menjadi pusat ekonomi negara. Hambatan-hambatan yang terjadi sebelum ditetapkannya kebijakan Doi Moi dikarenakan sebelumnya Vietnam terdiri dari 2 pembagian wilayah yang berbeda, yaitu Vietnam Utara dan Vietnam Selatan sehingga menyebabkan adanya perbedaan ideologi dimana Vietnam Utara menganut sistem ekonomi sentralistik sementara itu Vietnam Selatan menganut sistem ekonomi yang terbuka dan berorientasi pasar.

Dalam sistem politik vietnam, kekuasaan politik berada ditangan Partai Komunis Vietnam, khususnya di politbiro. ${ }^{28}$ Politbiro dapat disebut dengan inner core of party dimana didalamnya terdapat kumpulan anggota partai yang paling senior. Untuk menentukan suatu kebijakan yang akan diterapkan, maka yang memiliki pengaruh paling besar adalah anggota-anggota yang tergabung dalam Politbiro. Politbiro memiliki susunan tersendiri bagi masing-masing anggotanya. Nomor 1 anggota Politbiro (Sekretaris Jendral) merupakan orang yang memiliki kuasa tertinggi dalam menentukan keputusan, setelah itu ada sekretaris kedua (Perdana Menteri) dan

\footnotetext{
${ }^{27}$ Nguyen Thi Thu Hang dan Nguyen Duc Thanh, Macroeconomic Determinants of Vietnam 's Inflation 2000-2010: Evidence and Analysis, Vietnam Centre for Economic and Policy Research, Vietnam National University Hanoi, iakses melalui http://www.undp.org/content/dam/vietnam/docs/Publications/24590 InflationFinalReport-E-formatx.pdf pada tanggal 17 Desember 2017 pukul 20.59 WIB, hlm. 12.

${ }_{28}^{28}$ Alek Antariksa, Op, Cit. Hlm. 73.
} 
ketiga (Presiden). Seperti yang telah dijelaskan dalam bab 1, terdapat perdebatan antara kelompok konservatif dan reformis, tetapi keputusan tetap berada ditangan Sekretaris Jendral, yaitu Le Duan. Meskipun berasal dari kelompok konservatif yang tidak menginginkan perubahan sistem ekonomi berorientasi pasar, Le Duan memutuskan untuk mencoba penerapan sistem ekonomi yang digagas oleh Nguyen Van Linh.

Kongres partai ke-6 yang dilakukan oleh Partai Komunis Vietnam juga memberikan persetujuan untuk menghapus sistem manajemen perekonomian yang berpusat pada negara dan menggantinya dengan sistem perekonomian multi sektor dengan orientasi pasar yang bertujuan agar pihak swasta dapat ikut serta menjalankan roda perekonomian pada sektor non-strategis. Adanya investasi dari luar di Vietnam memiliki tiga tujuan utama, ${ }^{29}$ yaitu: Satu, pengembangan pertanian, Dua, perluasan produksi barang konsumsi dan Tiga, perluasan hubungan perdagangan dan investasi asing.

Berjalannya kebijakan Doi Moi memberikan pengaruh besar dalam perkembangan ekonomi Vietnam. Datangnya investor-investor asing seperti Jepang yang menanamkan modal di Vietnam membuat negara dapat membangun berbagai sektor ekonomi. Dalam perencanaan kebijakan lima tahun Doi Moi dari tahun 1986-1990 terdapat beberapa rincian tujuan kebijakan, ${ }^{30}$ yaitu : Satu, produksi yang cukup bagi konsumsi dan modal, Dua, menata kembali struktur ekonomi terutama investasi, Tiga, membangun sebuah hubungan produksi yang sesuai dengan karakter dan level kekuatan produksi, Empat, mengadakan perubahan sosial khususnya dalam masalah pekerja dan distribusi pendapatan, dan Lima, memperkuat pertahanan nasional dan keamanan internal.

Selain lima rencana kebijakan diatas, terdapat juga perencanaan-perencanaan lain yang dituju oleh adanya kebijakan Doi Moi untuk merubah perekonomian dan membuka keterlibatan Vietnam dalam pasar global, ${ }^{31}$ antara lain: Satu, liberalisasi harga, Dua, devaluasi secara besar-besaran dan penyatuan mata uang, Tiga, meningkatkan suku bunga ke tingkat positif secara rill, Empat, pengurangan secara

\footnotetext{
${ }^{29}$ Brian Van Arkadie dan Raymond Mallon, Op. Cit., hlm 68.

${ }^{30}$ Iva Rachmawati, M.Si, Latar Belakang Kebijakan Doi Moi di Vietnam, Universitas Pembangunan Nasional Yogyakarta. 2009, diakses melalui http://repository.upnyk.ac.id/6016/2/Vietnam_F.pdf pada tanggal 3 November 2017 pukul 16.05 WIB.

${ }^{31}$ Nguyen Thu Tuy et al., "Exploring Vietnam's Progress in Economic Growth”, Swiss Programme for Research on Global Issues for Development, 2015, hlm. 10.
} 
substansial subsidi pada sektor BUMN, Lima, reformasi agrikultur, Enam dorongan untuk sektor privat termasuk FDI (foreign direct investment), dan Tujuh penghapusan hambatan perdagangan domestik dan menciptakan ekonomi yang lebih terbuka.

Dibukanya perekonomian melalui orientasi pasar membuat adanya terdapat aturan yang ditetapkan bagi investor asing yang ingin menanamkan modalnya di Vietnam. Adanya aturan tersebut diharapkan dapat menarik lebih banyak investor asing untuk dapat menanamkan modalnya. Partai Komunis Vietnam berpendapat bahwa untuk menciptakan kondisi yang sesuai dengan harapan, maka negara harus memanfaatkan berbagai macam sektor potensial dengan memperluas hubungan antara negara melalui sektor perekonomian, sehingga peraturan ini disetujui oleh Majelis Nasional dan mulai diberlakukan tanggal 9 Januari $1988 .^{32}$

Berdasarkan Decision 217-HDBT, 14 November 1987, 'Renovating the Planning, Economic Accounting and Socialist Business of State Enterprises'. Subsequently, Statute 50-HDBT 'Regulations for State-Owned Industrial Enterprises', of March 1988 provided more details on the rights and responsibilities of state enterprises, The Council of Minister (Dewan Menteri) mengemukakan bahwa ada beberapa aturan yang harus dipatuhi untuk meningkatkan perekonomian, yaitu: Satu, perbedaan antara kepemilikan negara terhadap properti yang dialokasikan ke perusahaan, dan hak manajemen perusahaan untuk menggunakan dan secara langsung mengelola properti, Dua, hubungan antara perusahaan dan instansi pemerintah, Tiga, hak perusahaan mengenai perencanaan dan keputusan yang berkaitan dengan pengadaan, penjualan, penetapan harga, akuntansi keuangan, pekerjaan dan gaji dan Empat, hak terkait hubungan dagang antar perusahaan. ${ }^{33}$

Setelah Le Duan tidak menjadi Sekretaris Jendral Partai Komunis Vietnam, maka posisinya digantikan oleh Nguyen Van Linh. Keberadaan Nguyen Van Linh sebagai Sekretaris Jenderal yang baru diharapkan dapat mewujudkan berjalannya Doi Moi seperti yang telah direncanakan. Pada tanggal 1-9 April 1987, Partai Komunis Vietnam mengadakan sidang pleno ke-2 yang membahas mengenai bagaimanakah pembagian kewenangan antara posisi pemerintah dan Partai Komunis Vietnam dalam

\footnotetext{
${ }^{32}$ Tri, Vo Nhan, “Vietnam's Economic Policy Vietnam's Policy Since 1975”, Institute of Southeast asian Studies, Singapore, 1990,. Hlm. 45.

${ }_{33}^{33}$ Brian Van Arkadie dan Raymond Mallon, Op. Cit., hlm. 70.
} 
menjalankan perekonomian. Linh memberikan pandangannya terkait dengan perdebatan-perdebatan yang terjadi terkait dijalankannya kebijakan Doi Moi. Sebelum diterapkannya kebijakan Doi Moi, kelompok konservatif beranggapan bahwa sistem ekonomi yang berorientasi pada pasar merupakan sistem yang merujuk pada kapitalisme. Berdasarkan hal tersebut, Linh menyatakan bahwa Doi Moi merupakan bentuk manifestasi ekonomi modern melalui integrasi mekanisme pasar yang didalamnya terdapat keterlibatan pihak swasta dan investasi asing. ${ }^{34}$

Keterlibatan pihak swasta di Vietnam menyumbangkan $60 \%$ dari transaksi ekonomi yang ada. ${ }^{35}$ Pihak swasta inilah yang mendorong adanya orientasi pasar pada sistem perekonomian. Pada krisis ekonomi di Vietnam tahun 1986 sebelum Doi Moi diterapkan, pihak swasta dapat menjadi penggerak roda perekonomian dengan dukungan pengusaha kecil. Pada tulisan yang ditulis oleh Vo Nanh Tri, pemerintah mulai mempertimbangkan keberadaan sektor swasta dalam pembaruan ekonomi yang akan dilakukan melalui Resolusi No. 16 /NQTW oleh Politbiro tanggal 15 Juli 1988, dimana isi dari resolusi ini adalah memberikan kebebasan bagi pihak swasta berskala kecil diluar sektor publik untuk mengembangkan usahanya secara mandiri. ${ }^{36}$ Dengan diterbitkannya resolusi tersebut, maka pemerintah mengakui adanya peran pihak swasta dalam kegiatan ekonomi negara.

Selain adanya keterlibatan pihak swasta, terdapat juga penarikan investor asing melalui penanaman modal di Vietnam. Proses reformasi Doi Moi telah menghasilkan peningkatan standar hidup Vietnam yang diukur dengan GDP riil per kapita. Vietnam mulai menarik FDI (Foreign Direct Investment)/PMA (Penanaman Modal Asing) yang signifikan dari tahun 1988, hal ini dapat dikaitkan dengan pengundangan undangundang investasi asing liberal pada tahun 1987. FDI yang masuk ke Vietnam meningkat dari US \$ 0,32 miliar pada tahun 1988 menjadi sekitar US \$ 4,0 miliar pada tahun 2005, dengan tingkat pertumbuhan tahunan sebesar $28 \%$. ${ }^{37}$

\footnotetext{
${ }^{34}$ Dion Hardika Sumarto, Skripsi Penelitian: "Pembaruan Ekonomi (Doi Moi) di Vietnam 1986-1991" (Depok: Program Studi Ilmu Sejarah. Fakultas Ilmu Pengetahuan Budaya, Universitas Indonesia, 2007), hlm. 76.

${ }^{35}$ Ibid. Hlm. 89.

${ }^{36}$ Tri Vo Nhan. Op. Cit., hlm 202-204.

37 Sajid Anwar dan Lan Phi Nguyen, Foreign Direct Investment and Erowth in Vietnam, Asia Pacific Business Review Vol. 16, Nos. 1-2, January-April 2010, 183-202. University of the Sunshine Coast,
} 
Terkait keterlibatan investasi asing, pemerintah diharuskan untuk melakukan pendekatan dengan cara mengendalikan dan mengontrol keberadaan investasi asing sehingga investor lebih bebas untuk mengelola bisnis sehingga memperbanyak inovasi yang dilakukan pada sektor swasta, lalu pemerintah diharapkan dapat mengadopsi kinerja pihak swasta dan pihak investor asing dalam menjalankan usahanya melalui interaksi yang dilakukan oleh pemerintah dengan investor asing maupun pihak swasta, selain itu harus dilihat juga bagaimana peranan pemerintah untuk memberikan pembatasan sejauh mana keterlibatan investor asing untuk dapat bersaingin dengan sektor swasta domestik, serta bagaimana solusi yang dilakukan untuk meningkatkan daya saing bisnis agar dapat meningkatkan pertumbuhan dan produktivitas dalam negeri. ${ }^{38}$ Terkait dengan bentuk investasi yang akan dilakukan oleh investor asing di Vietnam, terdapat tiga hal yang menjadi bentuk penanaman modal asing, yaitu melalui kerjasama bisnis melalui sebuah kontrak, joint venture antara investor asing dengan pegiat ekonomi domestik Vietnam, perusahaan dimiliki sepenuhnya dan dijalankan melalui investasi asing. ${ }^{39}$

Adanya keterlibatan pihak swasta dan investor asing dalam proses berjalannya kebijakan Doi Moi tidak hanya menimbulkan dampak positif untuk meningkatkan perekonomian. Namun, terlibatnya pihak swasta dan asing bukan tanpa sebab. Tentunya harus ada timbal balik yang dihasilkan dari bantuan yang diberikan pada pemerintah. Salah satu dampak yang terjadi akibat masuknya investasi asing dan peranan pihak swasta dalam berjalannya kebijakan Doi Moi adalah tidak meratanya akses kesehatan antara masyarakat kaya dan miskin di Vietnam. Hal ini disebabkan karena pihak swasta mendirikan klinik pengobatan yang didasarkan pada komersialisasi layanan kesehatan, sehingga hanya segelinitir pihak yang dapat mengakses layanan kesehatan tersebut. Komersialisasi bisa terjadi karena kurangnya kontrol dari pemerintah atau adanya pertimbangan keuntungan yang diharapkan oleh pihak swasta terkait dengan pendirian klinik-klinik layananan kesehatan di Vietnam.

\footnotetext{
Australia and University of South Australia, Australia; National Economics University, Vietnam. Diakses melalui https://www.scribd.com/document/344006074/foreign-direct-investment-and-economic-growthin-vietnam-pdf pada 3 November 2017 17.30 WIB.

${ }^{38}$ United Nations Conference On Trade and Development (UNCTAD), Investment Policy Review Vietnam". New York and Geneva: United Nations. 2008, diakses dari http://unctad.org/en/Docs/iteipc200710_en.pdf hlm 125-126 pada 3 November 201717.00 WIB

${ }^{39}$ Tri Vi Nanh. Op. Cit., hlm 216-217.
} 


\subsection{Dampak Kebijakan Doi Moi Terkait Komersialisasi Bidang Kesehatan}

Liberalisasi ekonomi di dalam paket kebijakan Doi Moi nyatanya menghasilkan dampak berkelanjutan di dalam sektor kesehatan. Implementasi Doi Moi tersebut menghasilkan dampak yang kontradiktif dan tidak tepat sasaran dalam sektor kesehatan. Menurut Malhotra, perlu untuk mengindentifikasi dampak arahan kebijakan spesifik yang diambil di sektor kesehatan, terutama perubahan alokasi anggaran seperti penghapusan beberapa subsidi kesehatan yang memberi manfaat bagi kelompok miskin di sistem kolektif sebelumnya. Selain itu, Malhotra juga berpendapat bahwa meski Doi Moi menghasilkan pertumbuhan produksi, pendapatan dan konsumsi yang mengesankan, kendati demikian, Doi Moi juga menghasilkan kontradiksi dalam penyediaan layanan dasar. Perubahan struktural terhadap penyediaan dan akses di dalam sektor kesehatan menjadi dikelola oleh swasta sehingga menghasilkan sejumlah konsekuensi yang tidak terduga dan tidak disengaja sepanjang tahun 1990-an.

Dampak berkelanjutan dari liberalisasi ekonomi ini mencakup pengenalan sistem fee-for-service pada awal tahun 1990-an; diversifikasi sumber pembiayaan sektor kesehatan, dikombinasikan dengan perluasan praktik pribadi dan pengenalan sistem asuransi kesehatan pada pertengahan tahun 1990-an; pembedaan dalam mekanisme pembiayaan dan pengiriman antara program perawatan kesehatan primer dan penyediaan layanan kesehatan preventif dan kuratif; dan serangkaian tindakan kebijakan yang lebih baru yang dirancang untuk memperkenalkan pembebasan biaya untuk miskin dan untuk memperbaiki penargetan pembebasan ini sebagai tanggapan terhadap ketidaksetaraan dan perbedaan yang muncul dalam sistem. Reformasi kesehatan telah memobilisasi dan mendiversifikasi bentuk pembiayaan kesehatan melalui, di berbagai titik, seperti adanya biaya pengguna, asuransi kesehatan, praktik swasta, dan kontribusi publik. Hal ini meningkatkan fleksibilitas sektor kesehatan, namun masalah seperti kurangnya koordinasi yang memadai antara unsur-unsur sistem (misalnya skema asuransi kesehatan, fasilitas penyediaan layanan sektor publik, dan fungsi administrasi kesehatan seperti pengendalian biaya) telah menimbulkan sejumlah efek negatif terhadap ekuitas penyediaan layanan kesehatan dan akses yang dinikmati oleh orang miskin. Sedangkan meski sebelum Doi Moi diterapkan, di akhir 1970-an dan awal 1980-an perekonomian Vietnam menjadi memburuk, hal tersebut berbeda dengan sektor 
layanan sosial dimana sistem itu menyediakan akses layanan yang setara (seperti misalnya sektor pendidikan dasar). Selain itu sebelum pertengahan 1980-an, perawatan kesehatan juga disubsidi sepenuhnya oleh pemerintah. ${ }^{40}$

Pada awalnya, Partai Komunis Vietnam (PKV) ingin mengembangkan layanan kesehatan bagi masyarakat miskin melalui dana yang dimiliki negara, tetapi dana yang dimiliki oleh negara tidak cukup untuk menjalankan kebijakan tersebut, sehingga harus ada bantuan lain untuk menambah keuangan negara. Lalu investasi asing dan bantuan pihak swasta dijadikan sebagai solusi untuk memberikan layanan kesehatan yang lebih baik dengan tujuan agar setiap masyarakat bisa mengakses layanan kesehatan yang sama. Bantuan yang diberikan oleh pihak swasta dan dana investasi asing nyatanya masih belum cukup untuk memerbaiki layanan kesehatan di Vietnam. Pada akhirnya di tahun 1989 terdapat izin bagi penyedia layanan kesehatan untuk menambahkan dana yang dibebankan kepada masyarakat sehingga ada pemasukan tambahan untuk pelayanan kesehatan.

Penerapan reformasi kebijakan Doi Moi memiliki salah satu dampak negatif, yaitu membuat adanya ketidakmerataan yang terjadi antara masyarakat yang kaya dan miskin dalam mengakses layanan kesehatan. Karena sektor swasta berorientasi pada keuntungan, mereka menyediakan layanan terutama di daerah perkotaan. Akibatnya, masyarakat miskin pedesaan tidak memiliki akses terhadap layanan tersebut dan lemahnya rujukan kesehatan menimbulkan adanya perbedaan terkait biaya, kualitas layanan kesehatan serta distribusi layanan perawatan kesehatan di berbagai wilayah vietnam. Lalu, kesenjangan akses terhadap layanan kesehatan antara orang kaya dan masyarakat miskin menjadi meningkat, hal ini dijadikan sebagai pertimbangan oleh pihak swasta karena adanya perbedaan pendapatan dan kedekatan geografis dengan pusat kesehatan. ${ }^{41}$

\footnotetext{
${ }^{40}$ Edwin Shanks, Cecilia Luttrell, Tim Conway, Vu Manh Loi and Judith Ladinsky. Understanding ProPoor Political Change: the Policy Process: Vietnam. Overseas Development Institute, London, April 2004. Hlm. 52-53, diakses melalui https://www.odi.org/sites/odi.org.uk/files/odi-assets/publicationsopinion-files/3902.pdf pada 4 November 2017 pukul 18.23 WIB.

${ }^{41}$ Tran Thi Que \& To Xuan Phuci, Loc. Cit.
} 


\subsubsection{Anggaran Negara yang Tidak Seimbang Kepada Sektor Kesehatan}

Kebijakan terkait layanan kesehatan di era Doi Moi dianggap merugikan masyarakat, terutama bagi masyarakat berpenghasilan rendah. Dana yang dikeluarkan masyarakat lebih dari apa yang seharusnya dibayarkan. Kurangnya anggaran negara bagi layanan kesehatan disebabkan oleh proporsi PDB yang dialihkan pada sektor lain yang dianggap akan lebih menguntungkan dan dapat menyumbangkan dana besar bagi pertumbuhan ekonomi negara. Karena layanan kesehatan dianggap tidak terlalu menguntungkan dibandingkan dengan sektor lainnya.

Keterlibatan antara pemerintahan dan perusahaan negara mengakibatkan adanya kepentingan pribadi sehingga alokasi investasi dan sumber daya dapat diambil oleh various state economic groups dan corporate insiders, hal ini menyebabkan kebijakan ekonomi dan sosial dibuat untuk mendukung pejabat negara dan elit serta untuk orangorang yang mampu membayar. ${ }^{42}$ Belanja anggaran negara untuk perawatan kesehatan hanya mencakup $1-2 \%$ dari total PDB dan total 5\% dari total anggaran negara: 5,9\% pada tahun 1990 dan 4,8\% di tahun 2003. ${ }^{43}$ Pada Tahun 2007 anggaran belanja internasional untuk kesehatan vietnam hanya sekitar $6 \%$ dari anggaran pusat, sementara itu di tahun 2006, anggaran kesehatan Vietnam dari negara hanya berkisar 18\% dari pengeluaran publik untuk kesehatan. 44 Pengeluaran publik terdiri dari anggaran asuransi dan bantuan luar negri), sehingga sisanya sebesar 80\% ditanggung oleh masyarakat.

Data tersebut semakin menguatkan anggapan bahwa investasi sosial terutama layanan kesehatan tidak terlalu diprioritaskan. Hal ini menyebabkan adanya pengeluaran biaya out-of-pocket sehingga mau tidak mau masyarakat diharuskan membayar biaya untuk layanan kesehatan yang diluar kemampuannya. Selain menimbulkan adanya outof-pocket dari biaya layanan kesehatan, kurangnya investasi pemerintah dalam pendanaan kesehatan membuat komersialisasi layanan kesehatan tidak hanya dilakukan oleh pihak-pihak tertentu yang memiliki kuasa besar, namun juga dilakukan oleh para

\footnotetext{
${ }^{42}$ Ibid. Hlm 7.

${ }^{43}$ dikutip dari UNDP (1999) and MoH (2008). Dalam Ibid., hlm 8.

${ }^{44}$ Jonathan D. London, Reassertions of The State in Viet Nam's Health Sector, dikutip dalam M. Ramesh, Eduardo Araral Jr and Xun Wu. Reasserting the Public in Public Services: New Public Management Reforms. Routledge Studies in Governance and Public Policy. 2010. Hlm. 113-115.
}

\section{Universitas Indonesia}


staff medis dimana mereka telah membebankan biaya tambahan agar masyarakat dapat mengakses layanan kesehatan, selain itu mereka juga melakukan praktik jual beli obatobatan tanpa pengawasan dan belum tentu sesuai dengan diagnosa penyakit yang diderita karena tidak adanya kontrol terkait laporan medis pasien.

Subsidi terkait dana kesehatan yang diberikan pemerintah tidak cukup untuk memenuhi dana yang dibutuhkan oleh rumah sakit terkait pembiayaan layanan kesehatan. Seperti yang telah dibahas sebelumnya bahwa anggaran pemerintah cenderung dialihkan pada sektor ekonomi yang akan memberikan keuntungan lebih besar dibandingkan pelayanan sosial. Untuk mencukupi pemenuhan pembiayaan kesehatan, maka pemerintah memberikan otonomi kepada rumah sakit sebagai penyedia layanan kesehatan. Hal ini dikarenakan rumah sakit dapat mengetahui bagaimana pembagian dana untuk layanan kesehatan. Namun, kurangnya dana yang diberikan oleh pemerintah membuat rumah sakit harus mencari solusi terkait penyediaan dana kesehatan, sehingga dibebankanlah fee-for-service. Terkait strategi terhadap pembiayaan kesehatan di wilayah Asia Pasifik 2010-2015, maka WHO mengembangkan kerangka kerja bagi negara untuk mengevaluasi jangkauan layanan kesehatan secara menyeluruh melalui empat indikator, yaitu: Satu, total pengeluaran biaya kesehatan dengan jumlah paling sedikit 4-5\% produk domestik bruto, Dua, pengeluaran out-of-pocket tidak boleh lebih dari 30-40\% dari total pengeluaran kesehatan, Tiga, lebih dari 90\% populasi harus dilindungi oleh pre-payment (skema pembayaran dimuka) dan risk pooling scheme (skema penyatuan resiko), Empat, dekat dengan populasi yang membutuhkan bantuan sosial. ${ }^{45}$

Tetapi karena prioritas anggaran belanja negara adalah sektor-sektor ekonomi, hal tersebut menjadikan pemberian anggaran sektor sosial kurang diperhatikan. Walaupun telah ada investasi publik dan ODA (Official Development Assistance), namun pendanaan tersebut hanya didistribusikan di daerah pusat, sehingga investasi sosial dan ekonomi didaerah seperti di pedesaan, terdapat kesenjangan pembangunan daerah yang semakin cepat mengakibatkan kelompok yang berpenghasilan rendah

\footnotetext{
${ }^{45}$ Hong Teck Chua and Julius Chee Ho Cheah, Financing Universal Coverage in Malaysia: A Case Study, Article BioMed Central Public Health, 2012, (diakses melalui https://bmcpublichealth.biomedcentral.com/articles/10.1186/1471-2458-12-S1-S7 pada tanggal 17 Desember 2017 pukul 21.12 WIB.
} 
mendekati kemiskinan. Pendistribusian belanja negara yang dilakukan antara provinsi dapat dikatakan tidak berpihak pada orang miskin, padahal pihak yang mendistribusikan telah diberikan otonomi dan tanggung jawab atas pengeluaran daerah mereka, sehingga alokasi dana yang diberikan pada orang miskin sesuai dengan seharusnya. ${ }^{46}$ Meskipun ODA telah berpihak pada penduduk miskin, namun kenyataannya dana yang diberikan tidak berpihak pada penduduk miskin karena hanya mendapatkan kurang dari $7 \%$ dana ODA. ${ }^{47}$

\subsubsection{Kesenjangan Akses Kesehatan}

Ketidakmerataan yang terjadi antara masyarakat kaya dan miskin disebabkan oleh kendala terkait masalah keuangan dan kurangnya kontrol terhadap jalannya kebijakan yang melibatkan pihak swasta, sehingga mengakibatkan layanan primer komune tidak berjalan sesuai harapan. Padahal, tujuan awal dari adanya layanan primer komune adalah agar masyarakat mendapatkan akses layanan kesehatan gratis. Layanan primer komune merupakan perawatan dasar kesehatan serta pencegahan primer yang dapat diakses oleh masyarakat melalui jaringan pusat kesehatan masyarakat. Di sektor kesehatan, terdapat empat hal yang diperkenalkan terkait layanan kesehatan, di antaranya pengenalan biaya pengguna, pengenalan asuransi kesehatan, izin praktik swasta dibidang perawatan kesehatan dan pembukaan pasar farmasi. Berjalannya kebijakan tersebut membuat pembiayaan out-of-pocket meningkat sebesar $71 \%$ dari total biaya yang harus dikeluarkan pada bidang kesehatan tahun 1993. Pengeluaran outof-pocket mengalami peningkatan kembali pada tahun 1998 sebesar $80 \%$. ${ }^{48}$

Adanya komersialisasi dalam bidang kesehatan menurut Forsberg dapat dicontohkan melalui Rumah Sakit di Hanoi, dimana jika para pasien ingin mendapatkan layanan kesehatan yang baik, maka mereka diharuskan membayarkan biaya tambahan. Rumah sakit umum yang seharusnya memiliki tanggung jawab untuk menyediakan layanan kesehatan gratis terutama bagi masyarakat tidak mampu pun melakukan komersialisasi layanan kesehatan dengan menerapkan fee-for-service. Hal ini membuat

\footnotetext{
${ }^{46}$ Jonathan D. London, Op. Cit, hlm 6.

${ }^{47}$ Ibid.

48 Tran Van Tien, Hoang Thi Phuong, Inke Mathauer and Nguyen Thi Kim Phuong, World Health Organization: "A Health Financing Review Of Vietnam With A Focus On Social Health Insurance", Agustus 2011. Hlm 6. Diakses melalui http:/www.who.int/health_financing/documents/oasis f 11 vietnam.pdf pada tanggal 1 November 2017 pukul 19.39 WIB.
}

\section{Universitas Indonesia}


hanya orang-orang yang mampu membayar saja yang dapat mengakses layanan kesehatan, padahal pada kenyataannya yang membutuhkan layanan kesehatan tidak hanya orang-orang yang memiliki penghasilan tinggi. ${ }^{49}$

Di Vietnam, sistem perawatan kesehatan berada di bawah tanggung jawab swasta dan BUMN, yang dimana kedua badan ini bertanggung jawab untuk membiayai dan memelihara Pusat Kesehatan Komune (Commune Health Centres / CHCs) dan juga para petugas kesehatan. CHC menjadi semakin bergantung pada pendanaan negara melalui anggaran provinsi. Namun pada saat itu, jumlah ini tidak mencukupi untuk menjaga kuantitas dan kualitas layanan di Puskesmas di samping rumah sakit kabupaten dan provinsi, dan tingkat pengeluaran untuk penduduk lokal. Infrastruktur kesehatan, peralatan, obat-obatan dan staf menurun dengan cepat. Antara tahun 1985 dan 1990 jumlah pekerja kesehatan di tingkat akar rumput turun dari 59.000 menjadi 40.000 dan penggunaan rawat inap pasien dan pasien rawat jalan turun $50 \%$. 50

Layanan kesehatan dipusatkan di rumah sakit-rumah sakit yang ada di wilayah besar sehingga ada biaya yang lebih tinggi yang harus dibayarkan ketika masyarakat miskin membutuhkan layanan kesehatan yang lebih lengkap. Karena hal tersebut maka masyarakat miskin lebih memilih melakukan pengobatan di CHC (Commune Health Center) yang memiliki keterbatasan fasilitas kesehatan dan staff medis. Tetapi sayangnya, layanan kesehatan di tingkat lokal seperti $\mathrm{CHC}$ dikurangi sehingga ketika pasien tidak memiliki akses terhadap perawatan kesehatan lokal menjadi terlalu padat dengan layanan tingkat tinggi, rumah sakit mulai menciptakan standar pengobatan tingkat dua: satu untuk orang miskin dan satu untuk mereka yang dapat membayar. Kurangnya perawatan primer dan layanan di tingkat komune membuat adanya sistem rujukan ke tingkat yang lebih tinggi bagi orang miskin sehingga terdapat persaingan antara orang miskin dan orang kaya untuk mendapatkan layanan kesehehatan yang setara. Di bawah ini merupakan grafik yang berisikan perbedaan pendapatan antara masyarakat kaya dan miskin di Vietnam:

\footnotetext{
${ }^{49}$ Le Thanh Forsberg, Op. Cit, hlm 4-5.

${ }^{50}$ Ladinsky, et al. Loc. Cit
} 
Grafik 2.1 Perbedaan pendapatan antara masyarakat kaya dan miskin di Vietnam

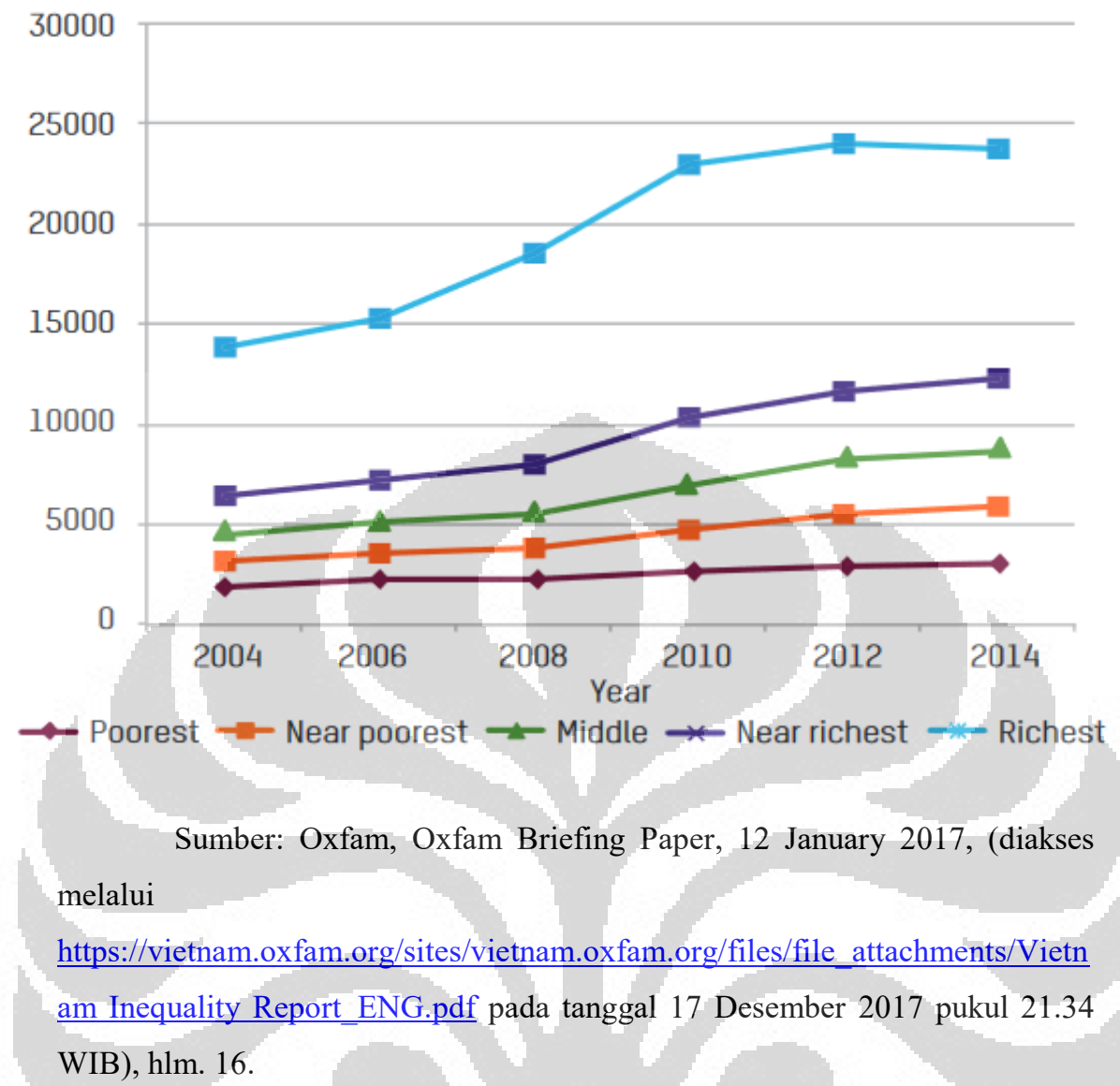

Grafik di atas menunjukan bahwa terdapat perbedaan yang signifikan antara pendapatan yang dimiliki oleh masyarakat miskin dan masyarakat yang kaya. Empat kuintil pertama memiliki perbedaan pendapatan yang tidak terlalu besar, namun dari near riches ke riches terdapat rentang pendapatan yang cukup jauh. Hal ini dicontohkan pada tahun 2014, pendapatan yang dimiliki oleh poorest berada dikisaran angka 3.5004.000, near poorest berada di angka 5.000-6.000, middle berada di angka 8500-9000, near richest berada pada kisaran angka 12.500 dan richest berada di angka 23.50024.000. Sehingga, grafik di atas menunjukan bahwa perbedaan pendapatan antara masyarakat kaya dan miskin semakin tinggi dari waktu ke waktu. Hal ini menyebabkan orang yang dapat mengakses layanan kesehatan tidak terlalu banyak dibandingkan dengan orang yang membutuhkan bantuan dana kesehatan, walaupun kuintil menengah (middle) tidak mendapatkan bantuan penuh seperti pada kuintil yang mendekati kemiskinan dan miskin, namun mereka sebaiknya mendapatkan bantuan kesehatan 
sehingga juga mendapat kemudahan akses layanan kesehatan. Hal ini dikarenakan rentang pendapatan yang cukup tinggi antara masyarakat kaya dan miskin, sehingga tentu lebih banyak yang membutuhkan dana bantuan kesehatan.

Kesenjangan ekonomi Vietnam akibat tidak meratanya pendapatan penduduk membuat hal tersebut berpengaruh terhadap akses lain, seperti contohnya akses kesehatan. Ketika melihat tingkat rawat inap, perbedaan antara orang yang paling miskin dan paling kaya cukup jauh, karena jika dilihat berdasarkan tabel dan interpretasi penulis, masyarakat miskin kurang memiliki akses untuk mendapatkan perawatan yang sebaik baiknya walaupun sebenarnya hal tersebut amat dibutuhkan, sementara itu masyarakat yang memiliki pendapat tinggi tentunya lebih mudah mendapatkan akses kesehatan. Masyarakat miskin, mungkin akan pergi ke rumah sakit apabila mereka memang benar-benar harus menjalani pengobatan secara serius karena minimnya keuangan yang mereka miliki.

Dalam menyikapi permasalahan terkait buruknya pelayanan di sektor kesehatan, maka pemerintah mengeluarkan beberapa kebijakan. Pada tahun 1989, CPV (yang bertindak melalui Majelis Nasional) memberikan kewenangan konstitusional kepada pemerintah untuk memperkenalkan iuran pengguna. Hal ini menjadi awal pencetusan Keputusan Perdana Menteri No. 45.

Seperti negara-negara berkembang lainnya, Vietnam sekarang menggunakan sumber keuangan publik (anggaran negara, dana asuransi kesehatan sosial dan bantuan internasional) dan dana pribadi (pembayaran langsung dari luar rumah tangga dan pengeluaran kesehatan swasta lainnya) untuk membiayai penyediaan layanan kesehatan. Sejak diterapkannya kebijakan Doi Moi pada tahun 1986, beberapa reformasi pembiayaan kesehatan telah berlangsung di Vietnam, hal ini dicontohkan dengan pengenalan biaya pengguna dan legalisasi praktik medis pihak swasta pada tahun 1989, adanya skema asuransi kesehatan di tingkat nasional pada tahun 1992, lalu di tahun 1993, terdapat program Pemberantasan Kelaparan dan Penanggulangan Kemiskinan (HEPR). HEPR merupakan seperangkat program yang dirancang untuk memperbaiki kesenjangan yang melebar antara daerah dengan pertumbuhan tinggi dan rendah di antara segmen populasi yang lebih kaya dan miskin dengan memperluas pengecualian kesehatan. Tahun 1994 terdapat pengambilalihan oleh pemerintah pusat atas tanggung 
jawab untuk membayar gaji ke staf kesehatan masyarakat di tingkat masyarakat dan juga pemerintah memperkenalkan Dekrit 95, yang menyatakan bahwa bagi masyarakat yang secara resmi dianggap miskin oleh pemerintah daerah mendapatkan sertifikat pembebasan biaya, dimana biaya kesehatan yang mereka terima akan diakomodir oleh anggaran reguler dari penyedia layanan kesehatan masyarakat setempat yang mengelola HEPR. ${ }^{51}$

Lalu di tahun 1998, pemerintah juga menetapkan pengaturan kelembagaan untuk pelaksanaan program-program ini. Program-program yang diberikan oleh pemerintah dalam praktiknya tidak berjalan sesuai dengan harapan karena tanpa rujukan atau sertifikat, masyarakat miskin hanya akan mendapatkan perawatan di CHS (Commune Health Station). Bila menggunakan kartu di rumah sakit mereka harus menunggu lama dibandingkan orang-orang yang memiliki dana lebih besar. Secara keseluruhan, upayaupaya pemerintah dalam pembebasan dan pengurangan biaya ini dikatakan belum berhasil karena belum dapat menjangkau seluruh populasi masyarakat miskin yang ada di Vietnam. Menurut Jonathan D. London, hal ini dikarenakan pembebasan biaya hanya mencakup satu komponen dari biaya layanan kesehatan.

Pemerintah selanjutnya berupaya dengan adanya otonomi finansial terkait alokasi dana layanan kesehatan. Dalam tulisan London mengemukakan, bahwa terdapat dua dekrit yang dikeluarkan oleh pemerintah, yaitu Dekrit 10 yang mulai diberlakukan pada tahun 2004, dan tahun 2006, Pemerintah mengeluarkan Keputusan 43/2006/NDCP mengenai otonomi keuangan, kepemilikan, dan pertanggungjawaban organisasi administrasi publik. ${ }^{52}$

Tujuan dari adanya dekrit tersebut adalah meningkatkan kualitas layanan publik dengan memberikan otonomi keuangan dan manajerial yang lebih besar pada unit layanan publik. Dekrit tersebut mendorong unit penyampaian layanan publik untuk membiayai peningkatan layanan dan membiayai gaji staf medis melalui pengembangan sumber pendapatan non-anggaran alternatif. Selain itu, dekrit tersebut juga mendorong

\footnotetext{
${ }_{51}^{51}$ Jonathan D. London, Op. Cit, hlm. 123.

${ }^{52}$ Van Minh Hoang, dkk. Patterns of Health Expenditures and Financial Protections in Vietnam $1992-$ 2012. J Korean Med Sci. 2015 Nov; 30(Suppl 2): S134-S138, diakses melalui https://www.ncbi.nlm.nih.gov/pmc/articles/PMC4659865/ pada tanggal 18 Desember 2017 pukul 12.35 WIB.
} 
unit layanan kesehatan mengadopsi model bisnis manajemen untuk memobilisasi sumber daya keuangan dari masyarakat. Artinya Dekrit 10 dan 43 yang diterbitkan menyalahi prinsip dan institusi formal yang mengatur penyediaan dan pembayaran untuk layanan publik di rumah sakit Vietnam sehingga mempengaruhi semua aspek pemberian layanan kesehatan dan semua segmen populasi. ${ }^{53}$

Sebagai pihak yang memahami dan memiliki wewenang terkait masalah kesehatan, Menteri Kesehatan dianggap lemah dalam melakukan pembangunan layanan kesehatan sehingga kebijakan layanan kesehatan tidak berjalan maksimal, padahal Undang-Undang Anggaran Tahun 2004 telah membebaskan Departemen Kesehatan untuk menerapkan kebijakan dengan cara mendahulukan, memobilisasi dan mengalokasikan sumber daya. Dalam artikel Forsberg dituliskan bahwa dari anggaran yang diberikan oleh pemerintah pusat untuk sektor kesehatan, lebih dari $60 \%$ nya digunakan untuk menggaji staf medis, lalu tunjangan dan asuransi untuk staf medis, sehingga alokasi dana yang seharusnya digunakan untuk membangun fasilitas kesehatan beserta layanannya menjadi kurang terpenuhi karena alokasi dana kesehatan nantinya akan dibagi untuk layanan kesehatan pusat dan untuk layanan kesehatan yang berada didaerah kecil (komune). Sehingga, pada akhirnya pembiayaan out-of-pocket pun tidak dapat dihindari untuk dapat memenuhi kebutuhan terkait pendanaan layanan kesehatan. 54

Meningkatnya keterlibatan swasta dalam menginvestasikan dananya semakin lama membuat posisi masyarakat miskin semakin tidak baik. Ketika masyarakat miskin tidak mampu membiayai akses kesehatan ditingkat yang lebih tinggi, maka mereka akan berobat ke layanan kesehatan masyarakat komune, namun seiring dengan bertambahnya keterlibatan pihak swasta yang menyebabkan akses dan kualitas $\mathrm{CHC}$ menurun, maka masyarakat miskin mengalami kesulitan untuk mengakses layanan kesehatan masyarakat. Terlebih ketika staff $\mathrm{CHC}$ memberikan rujukan agar masyarakat melakukan pengobatan medis yang lebih lengkap sehingga akan lebih banyak biaya yang harus dikeluarkan oleh masyarakat miskin untuk mendapatkan layanan kesehatan yang memadai.

\footnotetext{
${ }^{53}$ Jonathan D. London, Op, Cit, Hlm 130-131.

${ }^{54}$ Forsberg, Op. Cit., hlm. 17
} 


\subsubsection{Sistem Asuransi yang Tidak Memadai}

Hal lain yang juga perlu diperhatikan adalah tersedianya layanan asuransi dengan biaya yang cukup tinggi sehingga hanya orang-orang dengan penghasilan tertentu saja yang dapat menggunakannya. Vietnam telah melakukan perubahan terhadap sistem asuransi kesehatan. Terdapat 2 program yang digagas oleh pemerintah, yaitu yang bersifat wajib dan bersifat suka rela. Dalam program wajib terdapat empat skema pembagian yang harus dipahami, diantaranya: Satu, asuransi kesehatan sosial yang diperuntukan bagi para pekerja di sektor formal; dua, asuransi non-contributory dimana akses ini hanya bisa digunakan oleh orang-orang yang memiliki kontribusi terhadap negara; tiga, yaitu skema asuransi yang wajib diberikan kepada anak-anak dibawah usia 6 tahun agar dapat mengakses layanan kesehatan; dan keempat adalah Dana Kesehatan untuk Kaum Miskin (HCFP) yang diperkenalkan pada tahun 2003, hal ini dapat memberikan asuransi bagi mereka yang diklasifikasikan sebagai keluarga miskin dan etnis minoritas yang tinggal di daerah yang jauh dari pusat akses layanan kesehatan. $^{55}$

Tujuan awal dari adanya asuransi kesehatan adalah agar masyarakat miskin dapat mengakses layanan kesehatan secara gratis tanpa harus membayar. Tetapi terdapat permasalahan yang terjadi pada prosedur layanan kesehatan dengan menggunakan asuransi sehingga tujuan awal dari adanya asuransi untuk masyarat miskin tidak dapat terakses dengan baik. Ada beberapa biaya tidak formal yang harus dibayarkan oleh masyarakat miskin sehingga hal ini tertentu bertentangan dengan yang seharusnya terjadi. Layanan asuransi seharusnya dapat mempermudah masyarakat miskin untuk mengakses layanan kesehatan melalui bantuan dana dari pemerintah, tetapi kontrol dari berjalannya sistem asuransi yang ditetapkan menyebabkan adanya komersialisasi yang ditimbulkan dari adanya layanan asuransi. Staf medis yang ada pada sektor kesehatan dipusat kota terkesan tidak peduli terhadap layanan kesehatan yang seharusnya dapat menjangkau setiap kalangan, termasuk yang berpenghasilan rendah.

\footnotetext{
${ }^{55}$ G. Emmanuel Guindon, The Impact of Health Insurance on Health Services Utilization and Health Outcomes in Vietnam”. Health Economics Policy and Law (2014), 9, 359-382. Cambridge University Press, 2014, hlm. 359-360.
} 
Dengan data-data yang telah ditunjukkan di atas, maka proses sosialisasi layanan kesehatan yang dicetuskan oleh pemerintah Vietnam sejak masa kebijakan Doi Moi diimplementasikan pada era 1980-an secara tidak langsung artinya mengayomi sumber investasi swasta serta melibatkan penggunaan biaya, sehingga anggaran negara tidak terbebani. Sosialisasi yang dilakukan pada akhirnya menyebabkan layanan kesehatan yang harusnya dapat diakses oleh masyarakat miskin semakin memburuk. Alokasi dana yang seharusnya diberikan pada sektor kesehatan, pada praktiknya memberikan beban biaya tambahan yang diberikan terutama pada masyarakat miskin melalui penetapan biaya informal.

Dalam bab sebelumnya telah dituliskan bahwa komersialisasi menjadi salah satu penyebab ketidakmerataan layanan kesehatan yang terjadi di Vietnam. Hal ini kemudian telah diperkuat dengan beberapa artikel pada tinjauan pustaka yang menyatakan bahwa penyediaan layanan akses kesehatan bagi masyarakat miskin tidak lebih baik dibandingkan tersedianya akses layanan kesehatan bagi masyarakat kaya. Aturan-aturan terkait kebijakan yang diajukan sebagai solusi permasalahan bagi masyarakat miskin pun pada akhirnya tidak berjalan sesuai dengan harapan walaupun masih ada dampak positif yang ditimbulkan dari penerapan aturan tersebut. Kurangnya kontrol dan alokasi dana yang sedikit untuk sektor kesehatan dinilai menjadi salah satu penyebab masih adanya komersialisasi pada layanan kesehatan sehingga harus ada pengawasan yang lebih baik bagi pelayanan kesehatan. Pada bab selanjutnya akan membahas lebih rinci mengenai keterkaitan antara peraturan yang dibuat pemerintah aturan otonomi layanan kesehatan dengan dampak layanan kesehatan di Vietnam, kemudian hal tersebut akan dikaitkan dengan teori implementasi kebijakan publik yang dikemukakan oleh Daniel A. Mazmanian dan Paul A. Sabatier sehingga dapat dilihat apakah kebijakan Doi Moi yang telah diterapkan di Vietnam berhasil atau tidak. 


\section{BAB 3}

\section{IMPLEMENTASI DEKRIT 43 TAHUN 2006 TERKAIT LAYANAN KESEHATAN}

Penulisan pada bab 3 berfokus pada implementasi kebijakan era Doi Moi terkait sektor kesehatan, yaitu aturan otonomi layanan kesehatan pemerintah yang tercantum pada Dekrit 43 Tahun 2006. Dalam bab sebelumnya telah dituliskan bahwa aturan ini bertujuan agar masyarakat miskin bisa mendapatkan akses layanan kesehatan yang lebih baik dengan dana yang diberikan oleh pemerintah. Namun, alokasi dana kesehatan yang dimiliki oleh pemerintah pun nyatanya memiliki keterbatasan. Hal ini berdasarkan artikel yang telah ditulis oleh Jonathan D. London yang menyatakan bahwa dana yang seharusnya diberikan bagi layanan kesehatan tidak sepenuhnya diberikan sehingga harus ada pemasukan dana tambahan untuk bisa menyediakan layanan kesehatan yang sesuai dengan yang dibutuhkan masyarakat. Sehingga salah satu solusi yang diterapkan adalah penyediaan layanan asuransi yang diberikan pada masyarakat miskin, dimana biaya tersebut akan ditanggung oleh pemerintah melalui investasi swasta.

Pada bab ini, implementasi Dekrit 43 Tahun 2006 akan dikaitkan dengan analisis teori implementasi publik yang dikemukakan oleh Daniel A. Mazmanian dan Paul A. Sabatier. Teori tersebut berisikan tentang bagaimana keberhasilan suatu kebijakan dilihat dari tiga variabel yang saling berkaitan. Bab-bab sebelumnya telah menjelaskan mengenai latar belakang permasalahan yang terjadi pasca diberlakukannya kebijakan Doi Moi tahun 1986 disertai dengan tinjauan pustaka yang dapat memperkuat argumen terkait dampak yang ditimbulkan dari adanya penerapan kebijakan tersebut.

\subsection{Aturan Terkait Layanan Kesehatan Sebelum Diterapkannya Dekrit 43 Tahun} 2006

Sebelum membahas mengenai Dekrit 43 Tahun 2006 dan dampaknya dengan implementasi kebijakan Doi Moi, maka akan dibahas terlebih dahulu mengenai Dekrit 139/2002/QD-TTg terkait implementasinya dalam diagnosis dan layanan bagi pasien miskin. Pembahasan ini menjadi penting karena kebijakan ini tidak berjalan dengan 
efisien, sehingga pemerintah mengeluarkan kembali aturan terkait layanan kesehatan melalui Dekrit 10 Tahun 2002 dan Dekrit 43 Tahun 2006. Dekrit 139 telah menghasilkan perubahan mendasar dalam perawatan kesehatan bagi masyarakat miskin. Dapat dikatakan bahwa untuk pertama kalinya, semua kelompok masyarakat miskin dapat memperoleh manfaat langsung dari penerapan kebijakan layanan kesehatan dari negara. Penerapan Dekrit 139 membuat kemiskinan menjadi berkurang. Tetapi, tetap terdapat kesulitan dari adanya penerapan Dekrit 139, hal ini dikarenakan lambatnya identifikasi penerimaan manfaat asuransi sehingga hal tersebut mempengaruhi seberapa besar keberhasilan dari pelaksanaan Dekrit 139. ${ }^{56}$ Menurut sebuah survei kesehatan nasional yang dikemukakan dalam paper yang ditulis oleh IMF, hanya 8,9\% stasiun kesehatan komune yang mengembalikan biaya pengobatan kepada pasien yang menggunakan kartu asuransi kesehatan. ${ }^{57}$ Diagnosis dan kualitas pengobatan di tingkat komune masih terbatas sehingga pengembalian dana untuk perawatan pasien miskin di rumah sakit nasional menjadi lambat. Permasalahan ini membuat jumlah orang miskin kesulitan mendapatkan keuntungan dari layanan asuransi yang diberikan pada masyarakat miskin, selain itu. Sehingga dapat disimpulkan bahwa penerapan Dekrit 139 belum berjalan dengan baik.

Asuransi kesehatan wajib sendiri diperkenalkan pada tahun 1993, dimana asuransi diperuntukkan bagi pegawai pemerintah dan orang-orang yang berkerja di sektor formal. Sebelum Doi Moi, biaya layanan kesehatan dasar telah dibebaskan sehingga sebelum tahun 1989, sistem perawatan kesehatan dikelola secara terpusat dan disubsidi sepenuhnya oleh pemerintah. Oleh karena itu, layanan perawatan kesehatan diberikan secara gratis dari tingkat pusat sampai tingkat paling luar (seperti misalnya daerah-daerah dibagian yang letaknya cukup jauh dari perkotaan). Selama periode ini, walaupun memiliki GNP per kapita yang rendah dan menghabiskan sumber daya yang relatif rendah untuk jaringan layanan kesehatan, sistem perawatan kesehatan telah menghasilkan beberapa prestasi signifikan yang ditunjukkan oleh beberapa indikator

\footnotetext{
${ }^{56}$ Nguyen Thi Dan Thanh, The Vietnamese Social Health Insurance for The Near-poor: A Health Capability Approach, University of Oslo. 2013, diakses melalui https://www.duo.uio.no/bitstream/handle/10852/36605/Nguyen.pdf?sequence $=3$ pada tanggal 10 November pukul 11.33 WIB, hlm. 27.

57 IMF, Vietnam Poverty Reduction, Paper IMF September 2006. Diakses melalui https://www.imf.org/external/pubs/ft/scr/2006/cr06340.pdf pada tanggal 11 November 2017 pukul 22.26 WIB, hlm. 91-93.
} 
kesehatan vital seperti: tingkat harapan hidup dan tingkat kematian bayi yang rata-rata dapat dibandingkan dengan negara-negara kaya. Buruknya mekanisme pelayanan kesehatan ini membawa pemerintah mengeluarkan kebijakan yang memberikan otonomisasi bagi rumah sakit.

\subsection{Penerapan Dekrit 43 Tahun 2006 dan Dampaknya Bagi Layanan Kesehatan}

Pada tahun 2002, pemerintah telah menerapkan kebijakan mengenai otonomi keuangan badan layanan publik, dan kemudian kebijakan tersebut digantikan oleh Dekrit 43 Tahun 2006. Dekrit 43 Tahun 2006 mencakup otonomi keuangan badan layanan publik yang didasarkan oleh penghasilan badan negara, selain itu Dekrit 43 Tahun 2006 pun juga membahas mengenai sumber daya manusia. Tujuan dari pembentukan kebijakan ini adalah membantu rumah sakit untuk bertindak lebih profesional terhadap para pasiennya dengan cara menyusun ulang anggota staff medisnya, sehingga hal tersebut diharapkan akan mengurangi unsur komersialisme yang telah dilakukan oleh para staff medis rumah sakit sebelumnya. ${ }^{58}$ Badan layanan publik yang turut membantu pelaksanaan kebijakan pun diberikan izin oleh pemerintah agar dapat memobilisasi modal yang diberikan swasta sehingga kebutuhan masyarakat akan fasilitas kesehatan dapat terpenuhi. Pemberian otonomi pemerintah kepada rumah sakit terkait dengan dana anggaran yang digunakan untuk dana kesehatan telah memberikan izin agar rumah sakit dapat mengembangkan peraturan pengeluaran internal agar dapat meningkatkan efisiensi keuangan mereka. Namun, dalam setiap kebijakan yang dibuat, terdapat berbagai kemungkinan yang harus dihadapi. Terkait dengan kebijakan ini, maka tidak dapat dipungkiri bahwa implementasi otonomi rumah sakit dapat "mengundang" resiko yang didasarkan oleh insentif keuangan pasar agar dapat meningkatkan pendapatan. Untuk lebih memahami mengenai Dekrit yang dikeluarkan pemerintah terhadap akses layanan kesehatan, maka tabel di bawah ini akan menunjukan perbandingan antara dua dekrit yang saling berkaitan dalam penyediaan akses layanan kesehatan serta pemberian otonomi terhadap institusi tertentu:

\footnotetext{
${ }^{58}$ Ministry of Health Department of Planning and Finance Health Strategy and PolicyInstitute, "Lessons For Hospital Autonomy Implementation In Vietnam From International Experience”, The World Vietnam Office, diakses melalui https://openknowledge.worldbank.org/bitstream/handle/10986/27800/660140WP00PUBL0Lessons0for0 Hospital.pdf?sequence=1\&isAllowed=y pada tanggal 11 November 2017 pukul 00.11 WIB, Hlm iii.
} 


\subsection{Tabel Perbandingan Dekrit 10 Tahun 2002 dan Dekrit 43 Tahun 2006}

\begin{tabular}{|c|c|c|}
\hline Kategori & Dekrit 10 & Dekrit 43 \\
\hline Objektifitas & $\begin{array}{l}\text { Memberikan otonomi keuangan } \\
\text { kepada seluruh badan usaha } \\
\text { publik (termasuk rumah sakit) } \\
\text { untuk mengembalikan } \\
\text { pengeluaran mereka secara } \\
\text { penuh atau sebagian }\end{array}$ & $\begin{array}{l}\text { Memberikan otonomi keuangan } \\
\text { kepada semua badan usaha publik } \\
\text { yang memperoleh pendapatan untuk } \\
\text { memulihkan sebagian, penuh, atau } \\
\text { tidak ada pengeluaran berulang, dan } \\
\text { entitas publik khusus lainnya }\end{array}$ \\
\hline Manajemen biay & $\begin{array}{l}\text {-memberikan aturan terkait } \\
\text { pengelolaan dan pengeluaran } \\
\text { dana } \\
\text {-mengelola staf, mempekerjakan } \\
\text { pekerja sementara, menetapkan } \\
\text { tingkat upah dan tunjangan } \\
\text { sesuai pedoman } \\
\text {-menentukan } \\
\text { pengeluaran jumlah }\end{array}$ & $\begin{array}{l}\text {-menetapkan aturan terkait } \\
\text { manajemen dan pengeluaran } \\
\text { operasional untuk semua unit } \\
\text {-Membangun, menggabungkan, atau } \\
\text { membongkar unit subordinat } \\
\text {-menentukan ukuran, komposisi, dan } \\
\text { penugasan staf tetap, } \\
\text { mempekerjakan pekerja sementara, } \\
\text { menetapkan tingkat upah dan } \\
\text { tunjangan sesuai dengan pedoman } \\
\text {-menentukan jumlah pengeluaran } \\
\text {-menyesuaikan anggaran dengan } \\
\text { pengeluaran }\end{array}$ \\
\hline $\begin{array}{l}\text { jemen } \\
\text { apatan }\end{array}$ & $\begin{array}{l}\text { - membuka rekening bank, } \\
\text { meminjam atau mobilisasi } \\
\text { modal, adanya pemotongan atau } \\
\text { pembebasan pajak } \\
\text { - menentukan penggunaan } \\
\text { pendapatan, tetapi terdapat } \\
\text { pembatasan untuk anggaran } \\
\text { negara }\end{array}$ & $\begin{array}{l}\text { - membuka rekening bank, } \\
\text { meminjam modal, adanya } \\
\text { pemotongan dan pembebasan pajak } \\
\text { - menentukan penggunaan } \\
\text { pendapatan, tetapi terdapat } \\
\text { pembatasan untuk anggaran negara } \\
\text {-hak untuk membebankan biaya } \\
\text { pengguna }\end{array}$ \\
\hline Akuntabilitas & $\begin{array}{l}\text {-mengusulkan adanya anggaran } \\
\text { tahunan untuk PCOMs } \\
\text {-memberikan laporan keuangan } \\
\text { tahunan ke instansi negara } \\
\text { terkait }\end{array}$ & $\begin{array}{l}\text {-mengusulkan adanya anggaran } \\
\text { tahunan untuk PCOMs } \\
\text {-memberikan laporan keuangan } \\
\text { tahunan ke instansi negara terkait }\end{array}$ \\
\hline $\begin{array}{l}\text { Alokasi } \\
\text { pendapatan } \\
\text { bersih } \\
\text { (pengurangan } \\
\text { pengeluaran } \\
\text { berulang) }\end{array}$ & $\begin{array}{l}\text {-staf mendapat potongan } \\
\text { pertama (dari kontribusi dana } \\
\text { stabilisasi pendapatan, dana } \\
\text { penghargaan bonus, dan dana } \\
\text { kesejahteraan } \\
\text {-peningkatan upah kurang dari } \\
2.5 \text { untuk pemulihan instansi dan } \\
\text { kurang dari } 2 \text { untuk pemulihan } \\
\text { instansi secara parsial } \\
\text {-jumlah yang tersisa masuk } \\
\text { dalam Dana Pengembangan }\end{array}$ & $\begin{array}{l}-25 \% \text { pertama masuk ke dana } \\
\text { pembangunan untuk capital } \\
\text { expenditures } \\
\text {-lalu pendapatan tambahan dan iuran } \\
\text { digunakan Dana penghargaan, } \\
\text { pembatasan, dan pembatasan lainnya } \\
\text { berlaku untuk perusahaan yang } \\
\text { hanya memulihkan sebagian atau } \\
\text { tidak pengeluaran mereka. }\end{array}$ \\
\hline
\end{tabular}




\begin{tabular}{|l|l|l|}
\hline Kategori & \multicolumn{1}{|c|}{ Dekrit 10 } & Dekrit 43 \\
\hline & $\begin{array}{l}\text { Layanan Umum yang didasarkan } \\
\text { investasi modal }\end{array}$ & \\
\hline
\end{tabular}

Sumber: diolah sendiri oleh penulis dari Samuel S. Lieberman, Adam

Wagstaff, Op. Cit. hlm. 126.

Merujuk pada tabel di atas, terlihat bahwa Dekrit 43 Tahun 2006 memberikan gambaran yang lebih lengkap terkait hak dan wewenang rumah sakit sebagai pihak peyedia layanan kesehatan. Salah satu contoh bahwa Dekrit 43 Tahun 2006 sebagai penyempurna dari Dekrit 10 Tahun 2002 adalah pada Dekrit 43 Tahun 2006 dibagian manajemen pendapatan, pemerintah memberikan hak kepada rumah sakit untuk menentukan biaya pengguna untuk mendapatkan pendapatan alternatif. Hal ini lah yang pada akhirnya menimbulkan dampak negatif seperti yang akan dijelaskan di bawah ini.

\subsection{Analisis Implementasi Dekrit 43 Tahun 2006}

Otonomi yang diberikan pemerintah pada rumah sakit sebagai penyedia layanan kesehatan memberikan dampak yang kurang baik bagi rumah sakit sebagai penyedia layanan kesehatan. Keputusan No. 43/2006 / ND-CP menjamin bahwa direktur rumah sakit memiliki hak untuk mengendalikan manajemen keuangan, manajemen sumber daya manusia, pemberian layanan, dan bahkan biaya pengobatan. Selain itu direktur rumah sakit dapat memutuskan tambahan gaji, bonus, dan tunjangan untuk pekerja dalam $71 \%$ dari pendapatan bersih serta perekrutan dan menaikan jabatan staffnya. Namun, apa yang akan diberikan kepada rumah sakit tidak sebanding dengan besar dana yang dibutuhkan. Hal ini berdampak kepada pekerja rumah sakit untuk menjual jasanya dengan harga lebih tinggi. Mereka melakukannya dengan memberikan perawatan medis berteknologi lebih lanjut yang tidak tercakup dalam asuransi kesehatan, sehingga biaya perawatan kesehatan yang telah didanai oleh pemerintah tidak memenuhi kebutuhan layanan kesehatan masyarakat miskin. ${ }^{59}$

Di bawah ini merupakan tabel pengeluaran out-of-pocket berdasarkan pembayaran rumah tangga:

\footnotetext{
${ }^{59}$ Midori Matsushima dan Hiroyuki Yamada, Public Health Insurance in Vietnam Towards Universal Coverage: Identifying the Challenges, Issues, and Problems in Its Design and Organisational Practices, Journal of International Health Vol.29 No.4 2014, Osaka University, dikutip dari https://www.jstage.jst.go.jp/article/jaih/29/4/29_289/_pdf hlm. 290-295.
} 
Tabel 3.2 Out-of-pocket Berdasarkan Pembayaran Rumah Tangga Selama 12 Bulan Terakhir

\begin{tabular}{|c|c|c|c|c|}
\hline Tahun & $\begin{array}{c}\text { OOP } \\
\text { layanan } \\
\text { rawat jalan }\end{array}$ & $\begin{array}{c}\text { OOP } \\
\text { layanan } \\
\text { rawat inap }\end{array}$ & $\begin{array}{c}\text { OOP layanan } \\
\text { kesehatan } \\
\text { lain }\end{array}$ & Total OOP \\
\hline & VND 000 & VND 000 & VND 000 & VND 000 \\
\hline 2002 & 16,1 & 28,1 & 23,1 & 67,3 \\
\hline 2004 & 48,4 & 51,5 & 26,5 & 126,4 \\
\hline 2006 & 57 & 50,4 & 32,6 & 140 \\
\hline 2008 & 78,6 & 78,4 & 44,3 & 201,3 \\
\hline 2010 & 97,1 & 96 & 49,9 & 243 \\
\hline
\end{tabular}

Pocket Health Expenditure in Viet Nam: Findings From the National Living Standard Survey 2002-2010" (diakses mealui https://www.sciencedirect.com/science/article/pii/S0277953612007873 pada tanggal 29 Desember 2017 pukul 21.22 WIB)

Berdasarkan tabel di atas yang dituliskan oleh Hoang Van Minh, dkk, pengeluaran OOP yang berasal dari rumah tangga memiliki angka yang tinggi yaitu antara 50\%-70\%. Pembiayaan OOP yang tinggi dikaitkan dengan permasalahan pengeluaran rumah tangga dimana rumah tangga harus mengurangi pengeluaran kebutuhan lainnya. Dalam tabel tersebut, pembiayaan OOP dibagi menjadi tiga, yaitu berdasarkan biaya OOP rawat jalan, rawat inap dan pembiayaan layanan kesehatan yang lain. Pembiayaan OOP menjadi salah satu permasalahan terkait layanan kesehatan, dari tahun ke tahun pembiayaan OOP semakin meningkat. Tahun 2002 pada layanan rawat jalan, pengeluaran dana OOP berada di angka 16,1\%, tetapi pada tahun 2010, pengeluaran OOP meningkat menjadi 97,1\%. Pada layanan rawat inap tahun 2002, pengeluaran OOP berada di angka 28,1\%, namun di tahun 2010 pengeluaran OOP meningkat menjadi 96\%. Tidak jauh berbeda pada layanan rawat jalan dan rawat inap, dalam layanan kesehatan lainnya, OOP juga mendominasi pengeluaran pasien rumah sakit, seperti misalnya di tahun 2002, biaya pengeluaran OOP sebesar 23,1\%, sementara itu di tahun 2010 menjadi 49,9\%. Sehingga, pada tahun 2002, total pengeluaran OOP adalah 67,3\% dan tahun 2010 total pengeluaran OOP menjadi 243\%. Di tahun 2006, pemerintah telah mengeluarkan kebijakan otonomi layanan kesehatan, dimana hal 
tersebut bertujuan agar dapat meminimalisasi pengeluaran OOP karena adanya subsidi pemerintah dan pengaturan layanan kesehatan oleh rumah sakit, tetapi hal tersebut tidak membuat pengeluaran OOP terhadap layanan kesehatan menjadi menurun, sehingga OOP masih mendominasi sumber pendanaan layanan kesehatan.

Dapat dilihat bahwa pendapatan melalui fee for service masih mendominasi di Vietnam pasca penerapan Dekrit 10 Tahun 2002 dan Dekrit 43 tahun 2006. Hal ini juga mengindikasikan bahwa meski negara telah memberikan otonomi secara penuh kepada rumah sakit terkait manajemen anggaran, komersialisasi masih tetap terjadi.

\section{Tabel 3.3 Perbandingan Rumah Sakit dengan Otonomi Penuh dan Otonomi Parsial di Beberapa Wilayah}

\begin{tabular}{|c|c|c|c|c|c|c|}
\hline & Rumah S: & kit Pusat & $\begin{array}{l}\text { Rumah } \\
\text { Provinsi }\end{array}$ & Sakit & $\begin{array}{l}\text { Rumah } \\
\text { Distrik }\end{array}$ & Sakit \\
\hline & Cho Ray & $\begin{array}{l}\text { Uong } \\
\mathrm{Bi}\end{array}$ & $\begin{array}{l}\text { Nguyen } \\
\text { Tri } \\
\text { Phuong }\end{array}$ & $\begin{array}{l}\text { Quang } \\
\text { Ninh }\end{array}$ & $\begin{array}{l}\text { Thu } \\
\text { Duc }\end{array}$ & $\begin{array}{l}\text { Dong } \\
\text { Trieu }\end{array}$ \\
\hline Tingkat otonomi & Penuh & Parsial & Parsial & Parsial & Parsial & Parsial \\
\hline $\begin{array}{l}\text { Tingkat kunjungan } \\
\text { pasien }\end{array}$ & 1.197 .134 & 199.935 & 401.392 & 289.926 & 747.428 & 107.777 \\
\hline Tingkat rawat inap & 123.015 & 40.463 & 44.716 & 34.097 & 43.216 & 13.036 \\
\hline Jumlah dokter & 698 & 162 & 245 & 146 & 228 & 36 \\
\hline Jumlah suster & 1.483 & 294 & 498 & 288 & 369 & 63 \\
\hline $\begin{array}{ll}\text { Jumlah } & \\
\text { pendapatan } & \\
\text { Rumah } & \text { Sakit } \\
\text { (dalam } & \text { VND } \\
1.000 .000 .000)\end{array}$ & 2299,11 & 235,04 & 306,56 & 201,24 & 250,29 & 45,70 \\
\hline Anggaran Negara & $0 \%$ & $21,9 \%$ & $16,7 \%$ & $26,7 \%$ & $10,9 \%$ & $37,5 \%$ \\
\hline $\begin{array}{l}\text { Asuransi } \\
\text { kesehatan }\end{array}$ & $51,8 \%$ & $40,4 \%$ & $35,2 \%$ & $41,8 \%$ & $48,5 \%$ & $49,4 \%$ \\
\hline $\begin{array}{l}\text { Biaya pengguna } \\
\text { Rumah Sakit }\end{array}$ & $48,2 \%$ & $35,6 \%$ & $31,7 \%$ & $22,9 \%$ & $37,3 \%$ & $11,0 \%$ \\
\hline
\end{tabular}

Sumber: Data administratif Annual Hospital Reports. Dikutip dari Tran Thi Mai Oanh,dkk. Public hospital governance in Viet Nam, diakses melalui http://www.wpro.who.int/asia_pacific_observatory/country_comparative_st udies/ces public hospital 4_vnm.pdf pada tanggal 11 November 2017 pukul 13.31 WIB, hlm. 115. 
Berdasarkan tabel di atas, penelitian tersebut dilakukan dalam tingkatan rumah sakit yang dibagi menjadi tiga, yaitu rumah sakit pusat (terdiri dari Cho Ray dan Uong Bi), rumah sakit tingkat provinsi (terdiri dari Nguyen Tri Phuong dan Quang Ninh) dan rumah sakit kabupaten/distrik (terdiri dari Thu Duc dan Dong Trieu). Dari ke-enam rumah sakit yang telah disebutkan di atas, rumah sakit Cho Ray merupakan rumah sakit yang memiliki otonomi penuh, sementara itu lima rumah sakit lainnya memiliki otonomi sebagian.

Rumah sakit umum memiliki beberapa tantangan, seperti kesulitan dalam menyeimbangkan pendapatan dan pengeluaran rumah sakit yang didasarkan oleh keterbatasan dana, lalu tantangan selanjutnya adalah Kementrian Kesehatan dan Keuangan memerlukan anggaran negara terkait kegiatan tertentu, hal ini akan membatasi otonomi rumah sakit karena bergantung pada alokasi anggaran. ${ }^{60}$ Rumah sakit yang memiliki otonomi penuh seperti rumah sakit Cho Ray memiliki kapasitas yang besar untuk menyediakan layanan kesehatan dan dapat memperoleh dana yang besar dari adanya layanan asuransi sehingga kesulitan yang dihadapi rumah sakit hanya terkait alokasi dana untuk infrastruktur, peralatan medis dan untuk gaji staff medis. Sementara itu rumah sakit lain yang hanya memiliki otonomi sebagian seperti Uong Bi dan Dong Trieu, pembayaran yang didasarkan asuransi kesehatan diberlakukan dengan fee-for-service. Rumah sakit banyak yang melebihi batas asuransi pembayaran, dan berutang pada agen asuransi sosial (Jaminan Sosial Vietnam - VSS).

Rumah sakit dengan otonomi penuh untuk asuransi kesehatan memiliki persentase sebesar $51,8 \%$, hal ini tentu lebih besar jika dibandingkan dengan rumah sakit yang memiliki otonomi parsial, seperti di Rumah Sakit Uong Bi yang memiliki persentase 40,4\%. Beban besar yang dimiliki oleh Rumah Sakit Cho Ray yang memiliki otonomi penuh dikarenakan rumah sakit yang memiliki otonomi penuh artinya telah diberikan tanggungjawab dan wewenang oleh pemerintah untuk menyediakan layanan kesehatan bagi masyarakat, maka asuransi kesehatan yang dimiliki oleh rumah sakit cukup besar. Hal tersebut bertujuan agar asuransi dapat menjangkau masyarakat miskin. Jika asuransi yang berada di rumah sakit dengan otonomi penuh berjumlah sedikit,

\footnotetext{
${ }^{60}$ Tran Thi Mai Oanh, dkk. Op. Cit., hlm. 114-119.
}

\section{Universitas Indonesia}


maka akan terdapat pengeluaran OOP yang lebih besar untuk dapat memenuhi dana penyediaan layanan kesehatan di rumah sakit.

Selain permasalahan anggaran dana yang masih didominasi oleh OOP, pemerintah juga memiliki masalah dalam mencapai tujuan nasionalnya untuk mencapai pemerataan kepemilikan asuransi secara universal coverage. Dalam mekanisme tersebut, rumah sakit menjadi pihak yang memberikan asuransi terhadap para warga negara yang dianggap berhak menerima asuransi. Nyatanya, setelah memiliki hak dan wewenang melalui otonomisasi, rumah sakit masih memiliki kendala dalam mengidentifikasi calon penerima asuransi tersebut.

Dekrit 10 dan Dekrit 43 dinilai dapat mempengaruhi seluruh aspek layanan kesehatan di Vietnam. Adanya dekrit 10 dan 43 ditujukan untuk melihat kualitas dan aksesibilitas layanan kesehatan di Vietnam terutama rumah sakit bagi masyarakat miskin dan masyarakat yang mendekati angka kemiskinan. Keraguan atas pemberian otonomi dari pemerintah pada penyedia layanan kesehatan adalah memicu timbulnya komersialisasi dan perubahan layanan kesehatan. Namun, bagi pihak yang berpihak pada Dekrit 10 dan Dekrit 43 menyatakan bahwa dengan mengurangi ketergantungan rumah sakit terhadap anggaran pemerintah pusat, maka anggaran dapat dialokasikan pada pihak yang membutuhkan.

Tujuan dari dekrit ini adalah untuk meningkatkan kualitas layanan publik dengan memberikan otonomi keuangan dan manajerial yang lebih besar kepada unit layanan khusus. Dekrit tersebut memberikan hak pada penyedia layanan kesehatan terkait alokasi sumber keuangan, dan pengelolaan staff. Keputusan tersebut mendorong unit penyaluran layanan masyarakat untuk membiayai peningkatan layanan dan menyelesaikan biaya upah staf melalui pengembangan sumber pendapatan nonanggaran alternatif. Untuk tujuan ini, dekrit tersebut juga mendorong unit penyalur layanan untuk mengadopsi model bisnis manajemen agar dapat terus memobilisasi sumber daya keuangan dari masyarakat. ${ }^{61}$ Dekrit 43 diimplementasikan untuk mendorong pihak penyedia layanan kesehatan menerima pendapatan baru untuk meningkatkan kualitas dan jangkauan layanan kesehatan.

\footnotetext{
${ }^{61}$ Jonathan D. London, Reasserting The State in Viet Nam Health Care and the Logics of MarketLeninism, 2017, diakses melalui http://www.tandfonline.com/doi/full/10.1016/j.polsoc.2008.09.005 pada tanggal 9 November 2017 pukul 12.21 WIB, hlm 115-128.
} 
Artikel yang ditulis oleh Le Thanh Forsberg juga menguatkan argumen yang disebutkan diatas bahwa masyarakat miskin harus membayar lebih besar untuk dana kesehatan mereka dibandingkan dengan orang yang kaya. Jika orang kaya hanya membayar 5\% dari pendapatan mereka untuk dapat mengakses layanan kesehatan, maka orang miskin diharuskan membayar 8,4\% dari pendapatan mereka. ${ }^{62} \mathrm{Hal}$ ini tentunya menyebabkan ketidakmerataan antara masyarakat kaya dan miskin dalam mendapat layanan kesehatan. Pada awal 1990-an, pembayaran out-of-pocket mencakup lebih dari $70 \%$ untuk perawatan kesehatan. Pemanfaatan layanan kesehatan masyarakat turun drastis di tahun-tahun berikutnya. Fee-for-services memiliki efek buruk pada sistem layanan kesehatan karena fee-for-service meningkatkan ketidaksetaraan dalam hasil kesehatan. Berdasarkan sebuah studi tentang pembayaran out-of-pocket oleh Bitran (2012), Survei Pengukuran Standar Hidup yang dilakukan di Vietnam pada tahun 19921993 dan 1997-1998 menemukan bahwa biaya pengguna meningkatkan ketidaksetaraan kesehatan dalam hasil pelayanan kesehatan dan memperluas kemiskinan. ${ }^{63}$ Hal ini menyebabkan kondisi sosial masyarakat dalam mengakses layanan kesehatan menjadi tidak seimbang. Ketika masyarakat miskin harus melewati berbagai prosedur yang menyulitkan mereka untuk mendapatkan layanan akses kesehatan yang mereka butuhkan, maka masyarakat yang kaya akan dengan mudah mendapatkan layanan kesehatan karena mereka mampu membayar lebih untuk mendapatkan akses kesehatan. Tabel dibawah ini akan menjelaskan mengenai perbandingan antara masyarakat kaya dan miskin untuk melakukan perawatan kesehatan:

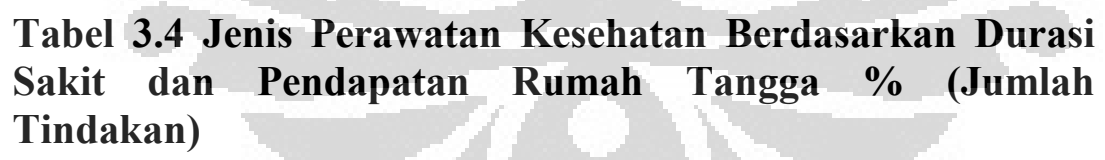

\begin{tabular}{|l|l|l|l|}
\hline & \multicolumn{3}{|c|}{ Durasi sakit } \\
\hline Pendapatan kelompok & 1-7 hari & $>7$ hari & Total \\
\hline Miskin & & & \\
\hline Perawatan rumah & $23(109)$ & $23(176)$ & $23(285)$ \\
\hline Obat bebas & $45(213)$ & $33(255)$ & $38(468)$ \\
\hline Konsultasi (Total) & $32(147)$ & $43(329)$ & $38(476)$ \\
\hline
\end{tabular}

\footnotetext{
${ }^{62}$ Le Thanh Forsberg, Op, Cit. hlm. 13.

${ }^{63}$ Bjorn Ekman, dkk. Health Insurance Reform in Vietnam: A Review of Recent Developments and Future Challenges, Health Policy and Planning, Volume 23, Issue 4, 1 July 2008, Pages 252-263, diakses melalui https://academic.oup.com/heapol/article/23/4/252/565025 pada tanggal 10 November 2017 pukul 12.33 WIB.
} 


\begin{tabular}{|l|l|l|l|}
\hline & \multicolumn{3}{|c|}{ Durasi sakit } \\
\hline Commune public & $24(110)$ & $22(171)$ & $23(281)$ \\
\hline Commune privat & $7(34)$ & $14(106)$ & $11(140)$ \\
\hline Rumah Sakit negara & $1(3)$ & $7(52)$ & $4(55)$ \\
\hline Tidak Miskin & & & \\
\hline Perawatan rumah & $28(71)$ & $24(80)$ & $25(151)$ \\
\hline Obat bebas & $35(90)$ & $32(107)$ & $33(197)$ \\
\hline Konsultasi (Total) & $37(97)$ & $44(150)$ & $42(247)$ \\
\hline Commune public & $26(68)$ & $22(75)$ & $24(142)$ \\
\hline Commune privat & $9(24)$ & $12(40)$ & $11(64)$ \\
\hline Rumah Sakit negara & $2(6)$ & $10(35)$ & $7(41)$ \\
\hline Total & & & \\
\hline Perawatan rumah & $25(180)$ & $23(256)$ & $24(436)$ \\
\hline Obat bebas & $42(303)$ & $33(362)$ & $36(665)$ \\
\hline Konsultasi (Total) & $33(244)$ & $43(479)$ & $39(723)$ \\
\hline Commune public & $24(178)$ & $22(246)$ & $23(423)$ \\
\hline Commune privat & $8(58)$ & $13(146)$ & $11(204)$ \\
\hline Rumah Sakit negara & $1(9)$ & $8(87)$ & $5(96)$ \\
\hline
\end{tabular}

Sumber: Economic Transition Should Come with a Health Warning: The Case of Vietnam, J Epidemiol Community Health 2002;56:497-505, diakses_melalui https://www.ncbi.nlm.nih.gov/pmc/articles/PMC1732209/pdf/v056p004 97.pdf pada tanggal 18 Desember 2017 pukul 12.27 WIB, hlm. 500.

Tabel di atas menunjukan bahwa 23\% rumah tangga masyarakat miskin memilih pengobatan di rumah, hal ini dikarenakan adanya keterbatasan dana yang mereka miliki untuk melakukan perawatan kesehatan, selain itu mereka lebih memilih mengobati sakitnya dengan obat bebas dan melakukan konsultasi pada layanan kesehatan komune dibandingkan rumah sakit yang dimiliki oleh negara. Akses menjadi salah satu permasalahan dari adanya tabel di atas, selain perbedaan pendapatan yang mereka miliki. Ketika orang miskin lebih banyak melakukan perawatan di rumah dan membeli obat-obat bebas, maka orang yang kaya cenderung lebih sedikit untuk melakukan hal tersebut. Hal ini dikarenakan mereka memiliki akses yang lebih mudah untuk mengakses layanan kesehatan di rumah sakit, walaupun akan ada dana tambahan yang dibebankan kepada mereka karena didasarkan oleh sistem fee-for-service.

Berdasarkan uraian tabel dan pembahasan permasalahan di atas, hingga saat ini reformasi kebijakan yang dilakukan di Vietnam belum dapat menjangkau seluruh kalangan, terutama masyarakat miskin. Walaupun pemerintah telah menerapkan asuransi layanan kesehatan dengan merujuk pada akses yang dapat diperoleh bagi masyarakat miskin, tetapi anggaran dana dan alokasi yang dijalankan masih belum bisa 
mewujudkan pemerataan layanan kesehatan. Kecenderungan alokasi dana untuk sektor lain membuat layanan kesehatan terbengkalai. Sehingga dapat disimpulkan bahwa kebijakan terkait layanan kesehatan belum berhasil. Hal ini dibuktikan dengan masih banyaknya biaya out-of-pocket yang harus dikeluarkan oleh masyarakat, selain itu perbedaan layanan kesehatan di pusat dengan di wilayah terpencil membuat masyarakat miskin membutuhkan dana tambahan untuk mengakses layanan kesehatan yang lebih baik.

Ditinjau berdasarkan analisis teori implementasi kebijakan publik yang disampaikan oleh Mazmanian dan Sabatier, terdapat tiga variabel yang harus dipahami untuk melihat apakah sebuah implementasi kebijakan dapat dikatakan berhasil atau tidak. Ketiga variabel tersebut adalah karakteristik masalah, karakteristik kebijakan dan lingkungan kebijakan. Namun, untuk menganalisis implementasi kebijakan maka salah satu poin yang diambil dari karakteristik masalah ialah tingkat kesulitan permasalahan. Lalu berdasarkan karakteristik kebijakan, poin yang digunakan adalah besarnya alokasi dana finansial untuk suatu kebijakan, tingkat komitmen pelaksana terhadap tujuan kebijakan dan bagaimana keterkaitan antara institusi pelaksana kebijakan. Terkait variabel lingkungan kebijakan, poin yang diambil adalah bagaimana pelaksana kebijakan membuat tujuan kebijakan dan apakah tujuan tersebut terealisasikan? ${ }^{64}$

Menurut pandangan Mazmanian dan Sabatier, tingkat kesulitan dari teknis masalah menjadi salah satu variabel penting yang dapat digunakan untuk menjelaskan karakter masalah. Hal ini dicontohkan oleh kedua penulis dari beberapa permasalahan sosial seperti kemiskinan, pengangguran, dan lainnya. Dalam permasalahan ini, kemiskinan di Vietnam merupakan masalah sosial yang sulit dipecahkan. Permasalahan kemiskinan ini menjadi tantangan dalam upaya rumah sakit dalam rangka pemerataan pelayanan kesehatan karena pendapat dan akses memiliki keterkaitan yang saling berhubungan, seperti yang telah dijelaskan oleh Forsberg.

Kendati demikian, implementasi Dekrit 43 tahun 2006 justru memperparah kondisi tersebut. Tindakan pemerintah dalam memberikan otonomi, secara tidak langsung memicu adanya komersialisasi. Hal ini menurut Mazmanian dan Sabatier dikarenakan keterpautan antara masing-masing intitusi pelaksana. Hal ini

${ }^{64}$ Herabudin, Op, Cit. hlm. 139-142. 
menyangkut hubungan antara pemerintah dengan rumah sakit. Rumah sakit sebagai penyedia layanan kesehatan memiliki kebebasan untuk mengatur pendanaan layanan kesehatan sehingga hal tersebut memungkinkan rumah sakit mengatur pendapatan mereka tanpa harus bergantung pada anggaran yang diberikan pemerintah. Otonomi yang diberikan pemerintah membuat adanya ketidakmerataan layanan kesehatan karena keterbatasan dana dan pengawasan yang dimiliki oleh pemerintah membuat membesarnya dana informal yang harus dikeluarkan oleh masyarakat.

Seperti yang telah dijelaskan di Bab 2, belanja anggaran negara untuk perawatan kesehatan hanya mencakup 1-2\% dari total PDB dan total 5\% dari total anggaran negara: 5,9\% pada tahun 1990 dan 4,8\% di tahun 2003. Tahun 2007 anggaran belanja internasional untuk kesehatan vietnam hanya sekitar $6 \%$ dari anggaran pusat, sementara itu di tahun 2006, anggaran kesehatan Vietnam dari negara hanya berkisar $18 \%$ dari pengeluaran publik untuk kesehatan. Pengeluaran publik terdiri dari anggaran asuransi dan bantuan luar negri), sisanya sebesar $80 \%$ ditanggung oleh masyarakat. Dari data di atas dapat disimpulkan bahwa sektor kesehatan tidak menjadi prioritas pemerintah, sehingga kebijakan terkait layanan kesehatan pun tidak didahulukan seperti sektor lainnya. Padahal kesehatan merupakan hal yang cukup penting untuk didahulukan, karena kesehatan berkaitan dengan sumber daya manusia, dimana sumber daya manusia yang baik dengan kesehatan yang memadai dapat mempengaruhi pembangunan negara.

Keterbatasan sumber daya finansial pada layanan kesehatan, menyebabkan penarikan biaya lain yang dibutuhkan untuk meningkatkan layanan kesehatan seperti misalnya untuk menutup biaya yang dikeluarkan oleh rumah sakit untuk menangani pasien yang dirujuk oleh asuransi pemerintah. Pemberian otonomi untuk pihak rumah sakit seperti yang telah dijelaskan, tidak menutup kemungkinan masih adanya komersialisasi layanan kesehatan, hal ini ketika dikaitkan dengan kasus diatas dijelaskan bahwa pemerintah tidak memiliki anggaran dana untuk masyarakat miskin yang tidak memiliki kartu asuransi namun membutuhkan layanan kesehatan

Hal tersebut selanjutnya yang memicu permasalahan dalam tingkat komitmen aparat terhadap tujuan kebijakan. Dekrit 43 tahun 2006 menekankan pemberian otonomi pada rumah sakit, sehingga rumah sakit memiliki kebebasan untuk menentukan 
dana yang dibutuhkan untuk memperbaiki layanan kesehatan yang akan diberikan pada masyarakat. Pemerintah mengalokasikan dana yang sedikit pada sektor kesehatan, sehingga untuk dapat menjangkau masyarakat miskin terhadap akses kesehatan, mau tidak mau rumah sakit melakukan komersialisasi layanan kesehatan yang berdampak pada pengeluaran berlebih masyarakat untuk membayar layanan kesehatan. Tujuan dari adanya dekrit 43 adalah memberikan kebebasan rumah sakit mengatur anggaran dan pekerjanya dalam rangka memberikan pemerataan pelayanan di dalam sektor kesehatan. Kendati demikian, hak yang diberikan pemerintah kepada aparat untuk membebankan biaya terhadap pengguna membuat komitmen tersebut tidak dijalankan secara maksimal. Dengan adanya hak tersebut, aparat rumah sakit kerap melakukan komersialisasi dengan memberikan pelayanan dengan tingkat harga yang tinggi untuk mendapatkan fee for service. Hal ini dilakukan dalam rangka mencari alternatif pendapatan. Menurut Mazmanian dan Sabatier, aparat pelaksana seharusnya menentukan prioritas tujuan kebijakan. Dalam kasus ini, aparat pelaksana harus melampaui dua kepentingan yang kontradiktif, yaitu kepentingan untuk pemerataan pelayanan serta pencarian pendapatan alternatif melalui komersialisasi.

Terkait salah satu bagian variabel lingkungan kebijakan yaitu, tingkat komitmen dan keterampilan dari aparat dan implementor, Mazmanian dan Sabatier menyatakan bahwa badan pelaksana kebijakan harus bisa membuat prioritas tujuan dan merealisasikan tujuannya. Pemerintah sebagai pihak yang mencetuskan kebijakan tersebut berupaya untuk menciptakan kesejahteraan terutama pada layanan kesehatan sehingga masyarakat miskin dapat mengakses layanan kesehatan, tetapi pemberian otonomi yang diberikan pada pihak rumah sakit membuat rumah sakit memiliki kebebasan untuk memberikan solusi dalam penyelesaian masalah akses kesehatan sehingga tujuan pemerintah tidak tercapai, walaupun telah ada beberapa upaya misalnya penyediaan asuransi yang dikhususkan untuk masyarakat miskin. Dalam kasus ini, sebaiknya pemerintah tidak memberikan otonomi kepada rumah sakit, karena pemberian otonomi pemerintah menimbulkan permasalahan baru seperti untuk mendapatkan dana tambahan, maka pihak rumah sakit membebankan layanan kesehatan lebih terhadap masyarakat sehingga tujuan yang ingin dicapai tidak terealisasi. 
Berdasarkan pemaparan di atas, telah dibahas mengenai aturan layanan kesehatan dimana aturan tersebut dibuat pemerintah agar masyarakat miskin mendapatkan kemudahan bagi layanan akses kesehatan. Kesulitan identifikasi pasien miskin untuk mendapatkan asuransi layanan kesehatan masih menjadi salah satu kendala pemerintah, karena masing-masing asuransi ditujukan bagi kalangan yang berbeda, misalnya terdapat perbedaan asuransi yang diperuntukan bagi masyarakat miskin dan masyarakat yang mendekati kemiskinan. Selain itu, fokus pemerintah pada pembangunan ekonomi, seperti yang telah dijelaskan pada bab sebelumnya membuat alokasi dana pemerintah pada bidang kesehatan tidak sebanding dengan yang dialokasikan pada bidang lainnya. Sehingga hal ini mempengaruhi proses kebijakan layanan kesehatan yang diperuntukan oleh masyarakat miskin. Untuk menciptakan pemerataan layanan kesehatan, maka pemerintah telah membuat beberapa peraturan salah satunya melalui Dekrit 43 tahun 2006. Isi dari dekrit ini membuat rumah sakit sebagai pihak penyedia layanan kesehatan bertanggung jawab atas permasalahan di bidang kesehatan karena otonomi yang telah diberikan oleh pemerintah. Tetapi terdapat sebuah permasalahan lagi, yaitu terbatasnya dana anggaran pada sektor kesehatan membuat rumah sakit harus mencari dana tambahan. Hal ini menyebabkan komersialisasi layanan kesehatan sehingga menimbulkan pembiayaan out-of-pocket dan layanan kesehatan pun pada akhirnya tetap mengacu pada fee-for-service. Sehingga, Dekrit 43 Tahun 2006 yang dibuat oleh pemerintah belum efektif pelaksanaannya karena pelaksanaannya tidak sesuai dengan apa yang diharapkan oleh pemerintah. Asumsi untuk menyelesaikan permasalahan ini adalah diperlukannya pengawasan pemerintah secara lebih karena dengan adanya otonomi yang diberikan pada rumah sakit, pemerintah terkesan memberikan kebebasan pada rumah sakit untuk menyediakan layanan kesehatan, hal ini tentunya mencakup tarif layanan kesehatan yang akan dibebankan pada pengguna layanan kesehatan.

Walaupun sebelumnya telah dijelaskan bahwa pemerintah telah menetapkan rincian biaya terkait layanan kesehatan, namun untuk menyediakan pelayanan kesehatan tersebut harus ada dana tambahan yang dikeluarkan rumah sakit. Masalah kembali muncul ketika ada orang miskin yang tidak dapat asuransi layanan kesehatan sehingga rumah sakit harus mengeluarkan dana tambahan untuk memberikan layanan kesehatan. Komersialisasi layanan kesehatan yang dilakukan oleh rumah sakit pada praktiknya 
tidak langsung memberikan keuntungan besar bagi rumah sakit, tetapi rumah sakit harus mengalokasikan dana tersebut untuk kas rumah sakit, untuk biaya staff medis, meningkat penyediaan layanan kesehatan dengan fasilitas yang memadai. Sehingga hal tersebut mendorong rumah sakit untuk mendapat dana tambahan yang lebih lagi. Dari pembahasan yang telah dilakukan pada bab 3, telah disimpulkan bahwa Dekrit 43 masih belum dapat memperbaiki akses layanan kesehatan di Vietnam secara menyeluruh bagi masyarakat miskin.

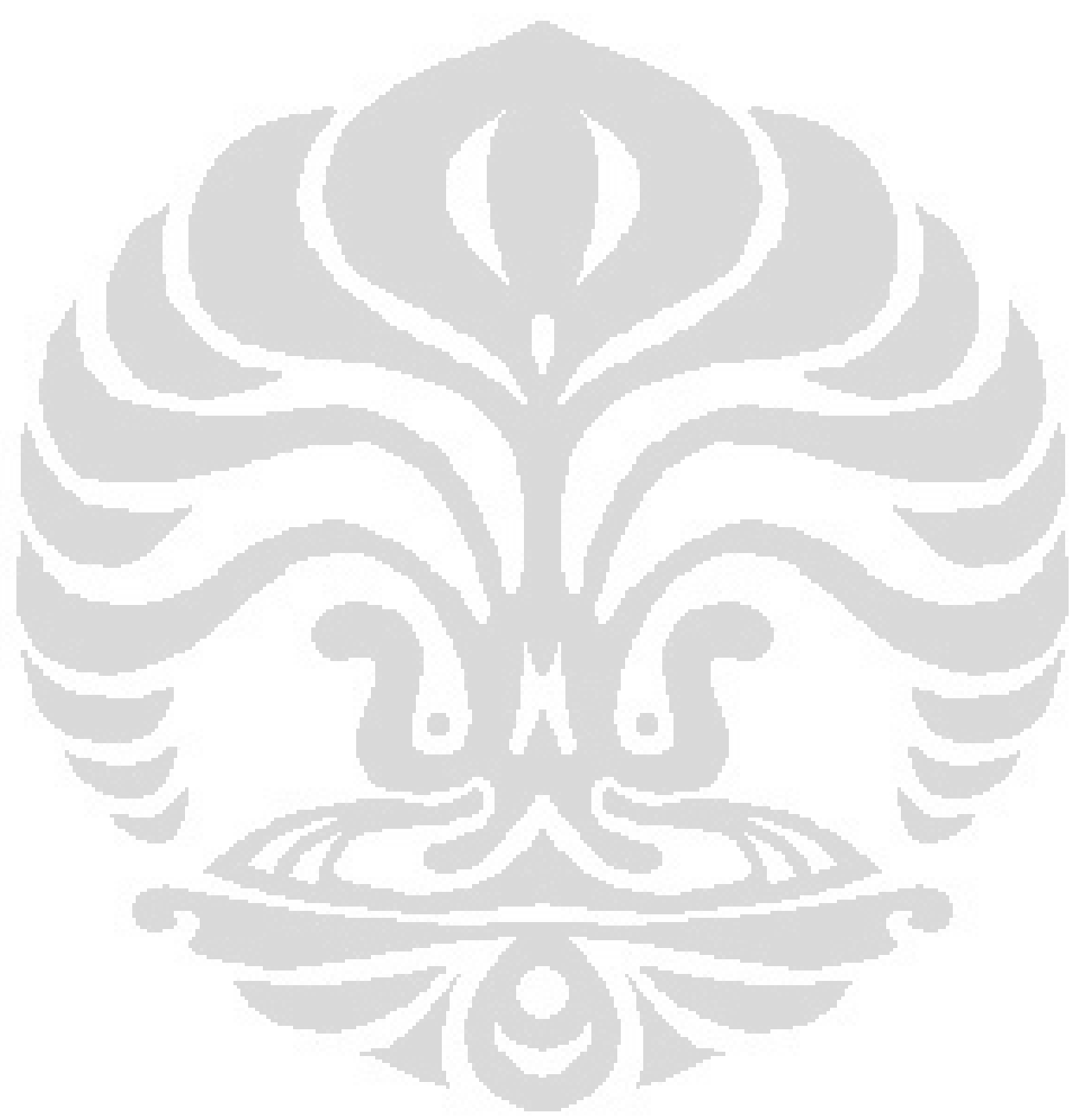




\section{BAB 4}

\section{KESIMPULAN}

Sebelum dilaksanakannya kebijakan Doi Moi, perekonomian Vietnam memiliki kondisi yang buruk. Namun di sisi lain sektor kesehatan terjamin dengan bentuk pemerataan serta subsidi layanan kesehatan. Pada tahun 1986 dimulailah reformasi ekonomi dengan ditetapkannya kebijakan Doi Moi. Kebijakan tersebut bertujuan untuk menaikkan perekonomian, namun dampak yang dihasilkan dari adanya kebijakan tersebut menimbulkan ketidakmerataan layanan kesehatan antara masyarakat kaya dan miskin. Hal ini terjadi karena fokus pemerintah didasarkan pada kemajuan sektor ekonomi, sehingga mengesampingkan anggaran untuk layanan sosial terutama layanan kesehatan. Kurangnya dana yang dialokasikan pada sektor kesehatan membuat penyedia layanan kesehatan harus mencari dana lain untuk dapat memenuhi kebutuhan layanan kesehatan bagi masyarakat miskin, sehingga hal tersebut menyebabkan komersialiasasi pada layanan kesehatan dengan menerapkan sistem fee-for-service. Penerapan Doi Moi ini justru menurunkan kualitas layanan kesehatan yang sebelumnya disubsidi penuh oleh pemerintah. Permasalahan komersialisasi layanan kesehatan terjadi setelah diterapkannya Doi Moi karena adanya otonomi yang diberikan oleh pemerintah pada pihak rumah sakit.

Dalam penerapan kebijakan Doi Moi yang diberlakukan pada tahun 1986, pemerintah berupaya untuk menaikkan perekonomian negara sehingga kehidupan masyarakat akan lebih sejahtera. Pada awal pelaksanaannya, dampak yang dihasilan dari kebijakan ini sesuai dengan harapan seperti perbaikan dana finansial negara. Sebelum Doi Moi diterapkan, terdapat perdebatan antara kelompok reformis dan sosialis, namun pada akhirnya kebijakan Doi Moi dapat dilaksanakan karena pemerintah ingin mencoba upaya baru untuk menaikkan perekonomian. Liberalisasi perekonomian merupakan cara yang ditempuh dalam pelaksanaan kebijakan. Penerapan kebijakan menimbulkan beberapa dampak negatif seperti masih terdapat ketidakmerataan antara masyarakat kaya dan masyarakat miskin dalam bidang kesehatan. 
Beberapa artikel yang sebelumnya telah disebutkan memberikan alasan bahwa layanan akses kesehatan masyarakat bergantung pada kondisi ekonomi dari masyarakat itu sendiri. Bagi masyarakat yang berpenghasilan tinggi, maka mereka dapat mengakses layanan kesehatan lebih mudah dibandingkan masyarakat yang memiliki keterbatasan dana. Selain itu, pengeluaran biaya kesehatan masyarakat miskin lebih tinggi dibandingkan masyarakat yang kaya, terlebih ketika fasilitas layanan kesehatan yang lengkap berada di pusat kota sehingga hal tersebut menambah biaya yang harus dikeluarkan untuk mendapatkan layanan kesehatan. Untuk mengatasi permasalahan tersebut, pemerintah mengeluarkan beberapa aturan, salah satunya Dekrit 139. Dekrit ini dianggap sebagai titik balik perbaikan layanan kesehatan yang didapatkan oleh masyarakat miskin Vietnam. Untuk menjangkau akses kesehatan bagi masyarakat miskin, pemerintah mengeluarkan asuransi kesehatan. Tetapi pada akhirnya kebijakan 139 tidak berjalan dengan baik karena lambatnya identifikasi penerimaan manfaat asuransi sehingga hal tersebut mempengaruhi keberhasilan dari pelaksanaan.

Permasalahan tersebut menyebabkan pemerintah mengeluarkan aturan terkait layanan kesehatan, yaitu Dekrit 43 Tahun 2006 yang membahas mengenai otonomi layanan kesehatan. Pemberian otonomi penuh dari pemerintah pada rumah sakit sebagai penyedia layanan kesehatan diharapkan memudahkan masyarakat miskin untuk mengakses layanan kesehatan. Dalam pelaksanaan kebijakan, pemerintah memberikan izin bagi penyedia layanan kesehatan untuk menentukan keputusan terkait solusi permasalahan layanan kesehatan. Selain itu, rumah sakit berikan izin untuk bisa memobilisasi modal swasta atau individu sehingga penyediaan layanan kesehatan dapat terpenuhi. Terkait pelaksanaan kebijakan layanan kesehatan, pemerintah telah memberikan anggaran tersendiri bagi layanan kesehatan, tetapi dana yang diberikan oleh pemerintah tidak cukup untuk mengelola layanan kesehatan. Karena itu, rumah sakit menerapkan pembebanan biaya tambahan untuk mengakses layanan kesehatan sehingga dapat mencukupi anggaran rumah sakit. Hal ini kemudian menyimpulkan bahwa pemberian otonomi tersebut berdampak pada komersialisasi layanan kesehatan dengan adanya pembebanan fee-for-service sehingga menyebabkan pembiayaan out-ofpocket. 
Kebijakan Doi Moi yang bertujuan untuk memperbaiki perekonomian dan kesejahteraan masyarakat Vietnam menimbulkan dampak yang kurang baik. Mazmanian dan Sabatier telah mengemukakan beberapa variabel yang digunakan untuk dapat mengukur keberhasilan atau kegagalan implementasi kebijakan. Ketika dikaitkan dengan teori tersebut, maka diasumsikan bahwa kebijakan terkait layanan kesehatan belum berjalan dengan maksimal. Hal ini dikarenakan terdapat beberapa komponen yang belum memenuhi tujuan kebijakan.

Untuk dapat memaksimalkan layanan kesehatan, maka diperlukan rincian pembiayaan kebutuhan rumah sakit. Setelah itu, pihak penyedia layanan kesehatan dapat mengajukan rincian pembiayaan tersebut terhadap pemerintah agar bisa menambahkan anggaran kesehatan yang akan dikelola oleh rumah sakit. Karena jika dana yang dibutuhkan untuk layanan kesehatan tidak mencukupi, maka sistem fee-forservice akan terus membebani masyarakat, sehingga tujuan pemerintah untuk dapat menjangkau layanan kesehatan bagi masyarakat miskin tidak dapat terpenuhi. Selain itu, dalam penulisan ini telah dituliskan bahwa tidak semua masyarakat miskin dapat menjangkau layanan kesehatan karena tidak teridentifikasi sebagai masyarakat miskin. Berdasarkan hal tersebut, maka pemerintah harus kompeten dalam mengidentifikasi memiliki kejelasan bagaimana penggolongan masyarakat miskin, apakah didasarkan pada penghasilan yang dimiliki atau indikator lainnya hal yang lain. Lalu, pemerintah sebaiknya mendata anggaran kebutuhan kesehatan masyarakat dan melakukan pengawasan maksimal terhadap dana kesehatan sehingga dana kesehatan dapat dialokasikan lebih pada daerah-daerah terpencil yang masyarakatnya memiliki keterbatasan dana untuk mengakses layanan kesehatan.

Penulisan ini diharapkan dapat menjelaskan bagaimana upaya yang dilakukan pemerintah untuk menciptakan pemerataan layanan kesehatan terutama bagi masyarakat miskin melalui otonomi yang diberikan pada badan penyedia layanan publik (rumah sakit). Namun, upaya yang dilakukan pemerintah pada akhirnya memiliki dampak yang kurang baik karena masih terdapat ketidakmerataan akses layanan kesehatan yang diperburuk dengan diberlakukannya sistem fee-for-service, sehingga terdapat biaya lebih yang seharusnya tidak dikeluarkan oleh masyarakat. Jika hal ini terus terjadi, maka pemerataan layanan kesehatan akan sulit tercapai. 


\section{DAFTAR PUSTAKA}

\section{Buku:}

Antariksa, Alek. (1996). Peran Kepemimpinan Reformis Nguyen Van Linh (1986-1991) dalam Menciptakan Keberhasilan Pembaharuan Ekonomi Doi Moi di Vietnam. (Fakultas Ilmu Sosial dan Ilmu Politik, Universitas Indonesia).

Arkadie, Brian Van dan Raymond Mallon. (2004). Vietnam: A Transition Tiger?. (Canberra: Asia Pasific Press).

Chan, Emily Ying Yang. (2018). Building Bottom-up Health and Disaster Risk Reduction Programmes. United Kingdom: Oxford University Press.

Drs. Herabudin, M.Si. (2016). Studi Kebijakan Pemerintah Dari Filosofi ke Implementasi. (Bandung: CV Pustaka Setia).

Edward III, George C and Ira Sharkansky. (1978). The Policy Predicament. (San Fransisco: W.H. Freeman and Company).

Lieberman, Samuel S. dan Adam Wagstaff (2009), Health Financing and Delivery in Vietnam: Looking Forward. (Washington, DC : World Bank).

Nguyen, Phuong, dkk. (2009). The Effect of a Poverty Reduction Policy and Service Quality Standards on Commune-Level Primary Health Care Utilization in Thai Nguyen Province, Vietnam. (London: Oxford University Press).

Sumarto, Dion Hardika. (2007). Pembaruan Ekonomi (Doi Moi) di Vietnam 1986-1991. (Fakultas Ilmu Sejarah, Universitas Indonesia).

Thanh Nghi, Pham. (2008). The State of Democratic Governance in Vietnam, Asian Barometer Conference on The State of Democratic Governance in Asia. Institute of Human Studies.

Tim Puskapol. (2014). Panduan Praktis Metode Penelitian Sosial. (Depok: Pusat Kajian Ilmu Politik).

USA International Business Publications. (2008). Vietnam Recent Economic and Political Developments Yearbook. (Washington: Global Investment Center).

Widodo, Joko. (2006). Analisis Kebijakan Publik. (Sidoarjo: Bayumedia Publishing).

\section{Jurnal Ilmiah:}


Anwar, Sajid dan Lan Phi Nguyen. (2010). Foreign Direct Investment and Economic Growth in Vietnam, Asia Pacific Business Review Vol. 16, Nos. 1-2, 183202. University of the Sunshine Coast, Australia and University of South Australia, Australia; National Economics University, Vietnam. Diakses melalui $\quad$ https://www.scribd.com/document/344006074/foreign-directinvestment-and-economic-growth-in-vietnam-pdf pada 3 November 2017 17.30 WIB.

Berliner, Tom dkk. (2013). Inequality, Poverty Reduction, and The Middle-Income Trap in Vietnam. EU Delegation to Vietnam. http://mekongeconomics.com/dev/images/stories/FILE\%20PUBLICATION S/EU\%20Blue\%20Book.pdf, diakses pada tanggal 15 Oktober 2016 pukul 13.10 WIB.

Chua, Hong Teck and Julius Chee Ho Cheah. (2012). Financing Universal Coverage in Malaysia: A Case Study. BioMed Central Public Health, diakses melalui https://bmcpublichealth.biomedcentral.com/articles/10.1186/1471-2458-12-

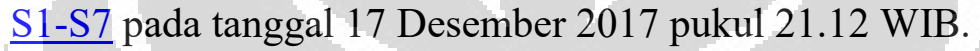

Dinh, Quan Xuan. (2000). The Political Economy of Vietnam's Transformation Process. Contemporary Southeast Asia, Vol. 22, No. 2 (August 2000), pp. 360-388. ISEAS - Yusof Ishak Institute, diakses melalui http://remotelib.ui.ac.id:2059/stable/pdf/25798497.pdf pada tanggal 18 Desember 2017 pukul 11.39 WIB.

Dinh, Quan Xuan. (1999). The State and The Social Sector in Vietnam: Reforms and Challenges for Vietnam. ASEAN Economic Bulletin, Vol. 16, No. 3, SOCIAL SECTORS IN SOUTHEAST ASIA: Role of the State (DECEMBER 1999), pp. 373-393. ISEAS - Yusof Ishak Institute, diakses melalui http://remote-lib.ui.ac.id:2059/stable/pdf/25773599.pdf pada tanggal 18 Desember 2017 pukul 11.29 WIB.

Duc, Nguyen Huu Chau, dkk. (2015). Trends in Inequalities in Utilization of Reproductive Health Services from 2000 to 2011 in Vietnam. Journal of Rural Medicine, diakses melalui https://www.ncbi.nlm.nih.gov/pmc/articles/PMC4689735/ pada tanggal 17 Desember 2017 pukul 20.23 WIB.

Ekman, Bjorn dkk. (2008). Health Insurance Reform in Vietnam: A Review of Recent Developments and Future Challenges, Health Policy and Planning, Volume 23, Issue 4, Pages 252-263, diakses melalui https://academic.oup.com/heapol/article/23/4/252/565025 pada tanggal 10 November 2017 pukul 12.33 WIB.

Forsberg, Le Thanh. (2010). The Political Economy of Health Care Reform in Vietnam. Princeton Global Leaders Fellow. Woodrow Wilson School of Public and International Affairs Princeton University, diakses melalui 
https://www.princeton.edu/ pcglobal/conferences/GLF/forsberg glf.pdf pada tanggal 16 Oktober 2016 pukul $11.01 \mathrm{WIB}$.

Fritzan, Scott. (2002). Growth, Inequality, and The Future of Poverty Reduction in Vietnam. Journal of Asian Economics 12, 635-657. (Singapore: National University of Singapore).

Galih, Pangesti Febri. (2012). Pelaksanaan Pelayanan Publik di Puskesmas Ngalik 1 Sleman Yogyakarta. (Yogyakarta: Universitas Negeri Yogyakarta)

Guindon, G. Emmanuel. (2014). The Impact of Health Insurance on Health Services Utilization and Health Outcomes in Vietnam. (Health Economics Policy and Law, 9, 359-382. Cambridge University Press)

Guo, Sujian. (2004). Economic Transition in China and Vietnam: A Comparative Perspective. Asian Profile. Vol 32, no. 5.

Hakkala, Katarina dkk. (2001). Step by Step: Economic Reform and Renovation in Vietnam before the 9th Party Congress. Working Paper No. 114. (Sweden: The European Institute of Japanese Studies).

Hoang Vuong, Quan. (2014). Vietnam's Political Economy in Transition (1986-2016), Article Stratfor Worldview (diakses melalui https://www.stratfor.com/thehub/vietnams-political-economy-transition-1986-2016 pada tanggal 15 Oktober 2016 pukul 13.44 WIB.

Hoang, Van Minh, dkk. (2015). Patterns of Health Expenditures and Financial Protections in Vietnam 1992-2012. J Korean Med Sci. 2015 Nov; 30 (Suppl 2): S134-S138., diakses melalui https://www.ncbi.nlm.nih.gov/pmc/articles/PMC4659865/ pada tanggal 18 Desember 2017 pukul 12.35 WIB.

Le, K.N. (2003). Investment of Rice Mills in Vietnam: "Economic Reforms in Vietnam”. University of Groningen, diakses melalui http://www.rug.nl/research/portal/files/13172312/c2.pdf pada tanggal 17 Oktober 2016 pukul 11.15 WIB.

London, Jonathan D. (2017). Reasserting the State in Viet Nam Health Care and the Logics of Market-Leninism, diakses melalui http://www.tandfonline.com/doi/full/10.1016/j.polsoc.2008.09.005 pada tanggal 9 November 2017 pukul 12.21 WIB.

London, Jonathan D., Reassertions of the State in Viet Nam's Health Sector, dikutip dalam M. Ramesh, Eduardo Araral Jr and Xun Wu (2010) Reasserting the Public in Public Services: New Public Management Reforms. (Routledge: Routledge Studies in Governance and Public Policy). 
Matsushima, Midori dan Hiroyuki Yamada, (2014). Public Health Insurance in Vietnam towards Universal Coverage: Identifying the Challenges, Issues, and Problems in Its Design and Organisational Practices, Journal of International Health Vol.29 No.4, Osaka University, dikutip dari https://www.jstage.jst.go.jp/article/jaih/29/4/29_289/_pdf pada tanggal 11 November 2017 pukul 01.00 WIB.

Ministry of Health Department of Planning and Finance Health Strategy and Policy Institute, (2011). Lessons For Hospital Autonomy Implementation In Vietnam From International Experience, The World Vietnam Office, diakses melalui https://openknowledge.worldbank.org/bitstream/handle/10986/27800/66014 0WP00PUBL0Lessons0for0Hospital.pdf? sequence $=1 \&$ isAllowed $=y$ pada tanggal 11 November 2017 pukul 00.11 WIB.

Nguyen Thu Tuy et al., (2015). Exploring Vietnam's progress in economic growth, Swiss Programme for Research on Global Issues for Development

Nguyen, Thang Minh and Barry M. Popkin. (2003) Income and Health Dynamics in Vietnam: Poverty Reduction, Increased Health Inequality. Population (English Edition, 2002-), Vol. 58, No. 2 (Mar. - Apr., 2003), pp. 253-264. Institut National d'Etudes Démographiques, diakses melalui http://remotelib.ui.ac.id:2059/stable/pdf/3246605.pdf pada tanggal 18 Desember 2017 pukul 11.34 WIB.

Oxfam. (2017). Even it Up: How to Tackle Inequality in Vietnam. Oxfam: Labor and Social Publishing House. Oxfam Briefing Paper 12 January 2017 (diakses melalui

https:/vietnam.oxfam.org/sites/vietnam.oxfam.org/files/file attachments/Vi etnam Inequality Report_ENG.pdf pada tanggal 17 Desember 2017 pukul 21.34 WIB.

Pham, Bao. The Economic Reform in Vietnam in 1989: "Shock Therapy or Gradualism?”. (2003). (San Diego: University of California), diakses melalui

http://econweb.ucsd.edu/ rstarr/191AB\%20Fall\%202016\%20Winter\%2020 17/ExemplaryPapers2016/Economic $\% 20$ Reform $\% 20$ in $\% 20$ Vietnam.pdf pada tanggal 17 Desember 2017 pukul 20.38 WIB.

Rachmawati, Iva. (2009) Latar Belakang Kebijakan Doi Moi di Vietnam, Universitas Pembangunan Nasional Yogyakarta, diakses melalui http://repository.upnyk.ac.id/6016/2/Vietnam_F.pdf pada tanggal 3 November 2017 pukul 16.05

Segall, M, dkk. (2002). Economic Transition Should Come With a Health Warning: The Case of Vietnam. J Epidemiol Community Health 2002;56:497-505. (diakses

melalui 
https://www.ncbi.nlm.nih.gov/pmc/articles/PMC1732209/pdf/v056p00497.p df pada tanggal 18 Desember 2017 pukul 12.27 WIB)

Shanks, Edwin. (2004). Understanding Pro-Poor Political Change: the Policy Process: Vietnam. Overseas Development Institute, London, diakses melalui https://www.odi.org/sites/odi.org.uk/files/odi-assets/publications-opinionfiles/3902.pdf pada 4 November 2017 pukul 18.23 WIB.

Szalontai, Balazs. (2008). The Diplomacy of Economic Reform in Vietnam: The Genesis of Doi Moi, 1986-1989. Mongolia International University, Visiting Professor, diakses melalui http://www.coldwar.hu/html/en/publications/Doi\%20Moi\%20Article.pdf pada tanggal 17 Oktober 2016 pukul 10.20 WIB.

Taylor, Philip. (2007). Poor Policies, Wealthy Peasants: Alternative Trajectories of Rural Development in Vietnam. Journal of Vietnamese Studies, Vol. 2, No. 2 (Summer 2007), pp. 3-56. University California Press, diakses melalui http://remote-lib.ui.ac.id:2059/stable/pdf/10.1525/vs.2007.2.2.3.pdf pada tanggal 18 Desember 2017 pukul 11.24 WIB.

Thanh, Nguyen Xuan, dkk. (2013). The Impact of Economic Growth on Health Care Utilization: A Longitudinal Study in Rural Vietnam. Official Journal of The International Society for Equity in Health 2013, diakses melalui https://equityhealthj.biomedcentral.com/articles/10.1186/1475-9276-12-19 pada 16 Oktober 2016 pukul 10.41 WIB.

Thanh, Nguyen Xuan dan Lars Lindholm. (2012). Has Vietnam Health Care Funds for The Poor Policy Favored the Elderly Poor?, Article BioMed Central., diakses melalui https://www.ncbi.nlm.nih.gov/pmc/articles/PMC3514242/ pada tanggal 17 Desember 2017 pukul 20.33 WIB.

Thi Que, Tran and To Xuan Phuci. (2003). La Politique du Moi Doi et Son Impact Sur Les Pauvres. Centre for Gender, Environment and Sustainable Development Studies, diakses melalui http://www.socialwatch.org/sites/default/files/pdf/en/vietnam2003 fran.pdf pada tanggal 15 Oktober 2016 pukul 12.16 WIB.

Thi, Nguyen Dan Thanh. (2013). The Vietnamese Social Health Insurance for the Near-Poor: A Health Capability Approach, University of Oslo, diakses melalui

https://www.duo.uio.no/bitstream/handle/10852/36605/Nguyen.pdf?sequenc $\underline{\mathrm{e}=3}$ pada tanggal 10 November 2017 pukul 11.33 WIB.

Thuan, Nguyen Thi Bich, dkk. (2006). Household Out-of-pocket Payments for Illness: Evidence from Vietnam. BioMed Central Public Health Article. (diakses melalui https://www.ncbi.nlm.nih.gov/pmc/articles/PMC1660562/ pada tanggal 18 Desember 2017 pukul 12.22 WIB. 
Tien, Tran Van dkk. (2011). World Health Organization: "A Health Financing Review Of Vietnam With A Focus On Social Health Insurance", Agustus 2011. Hlm 6

Diakses melalui http://www.who.int/health financing/documents/oasis f 11-vietnam.pdf pada tanggal 1 November 2017 pukul 19.39 WIB

Tsuboi, Yoshiharu. (2007). Twenty Years After the Adoption of the Doi Moi Policy. Graduate School of Political Science Waseda University. (diakses melalui https://dspace.wul.waseda.ac.jp/dspace/bitstream/2065/12801/1/43 070321Tsuboi-e.pdf pada tanggal 15 Oktober 2016 pukul $14.22 \mathrm{WIB}$ )

Vo Nhan, Tri. (1990). Vietnam's Economic Policy Vietnam's Policy Since 1975, Institute of Southeast asian Studies, Singapore.

Vuong, Quan Hoang. (2014). Vietnam's Political Economy: A Discussion on the 19862016 Period. (Belgium: Centre Emile Bernheim)

Vuong, Quan Hoang. (2015). Be Rich or Don't Be Sick: Estimating Vietnamese Patients' Risk of Falling Into Destitution. (diakses melalui https://www.ncbi.nlm.nih.gov/pmc/articles/PMC4577521/ pada tanggal 18 Desember 2017 pukul 11.43 WIB)

Wagstaff, Adam. (2002). Poverty and Health Sector Inequalities. Bulletin of the World Health Organization melalui https://www.scielosp.org/pdf/bwho/v80n2/a04v80n2.pdf pada tanggal 17 Desember 2017 pukul 20.05 WIB)

\section{Institusi:}

International Monetary Fund (IMF). (2006). Vietnam Poverty Reduction, Paper IMF September 2006. Diakses melalui https://www.imf.org/external/pubs/ft/scr/2006/cr06340.pdf pada tanggal 11 November 2017 pukul 22.26 WIB.

United Nations Conference On Trade and Development (UNCTAD). (2008). Investment Policy Review Vietnam". New York and Geneva: United Nations, diakses dari http://unctad.org/en/Docs/iteipc200710 en.pdf hlm 125-126 pada 3 November 2017 17.00 WIB.

World Health Organization (WHO). (2009). Health Financing Strategy for The Asia Pasific Region

(2010-2015). http://www.wpro.who.int/publications/docs/Healthfinancingstrategy 6188.p df, diakses pada tanggal 17 Desember 2017 pukul 20.28 WIB.

WHO dan Ministry of Health Vietnam, (2012), Health Service Delivery Profile Viet Nam, diakses melalui http://www.wpro.who.int/health_services/service_delivery profile_vietnam.pdf pada tanggal 9 November 2017 pukul 13.24 WIB. 
World Health Organization (WHO) .(2010). World Health Statistic, diakses melalui http://www.who.int/whosis/whostat/EN WHS10 Full.pdf pada tanggal 16 Oktober 2016 pukul 17.33 WIB.

World Bank (2012). Well Begun, Not Yet Done: Vietnam's Remarkable Progress on Poverty Reduction and the Emerging Challenges. Vietnam Poverty Assessment. Hanoi: World Bank Document, diakses melalui http://documents.worldbank.org/curated/en/563561468329654096/pdf/7491 00REVISED00al000Eng000160802013.pdf pada tanggal 18 Desember 2017 pukul 11.23 WIB.

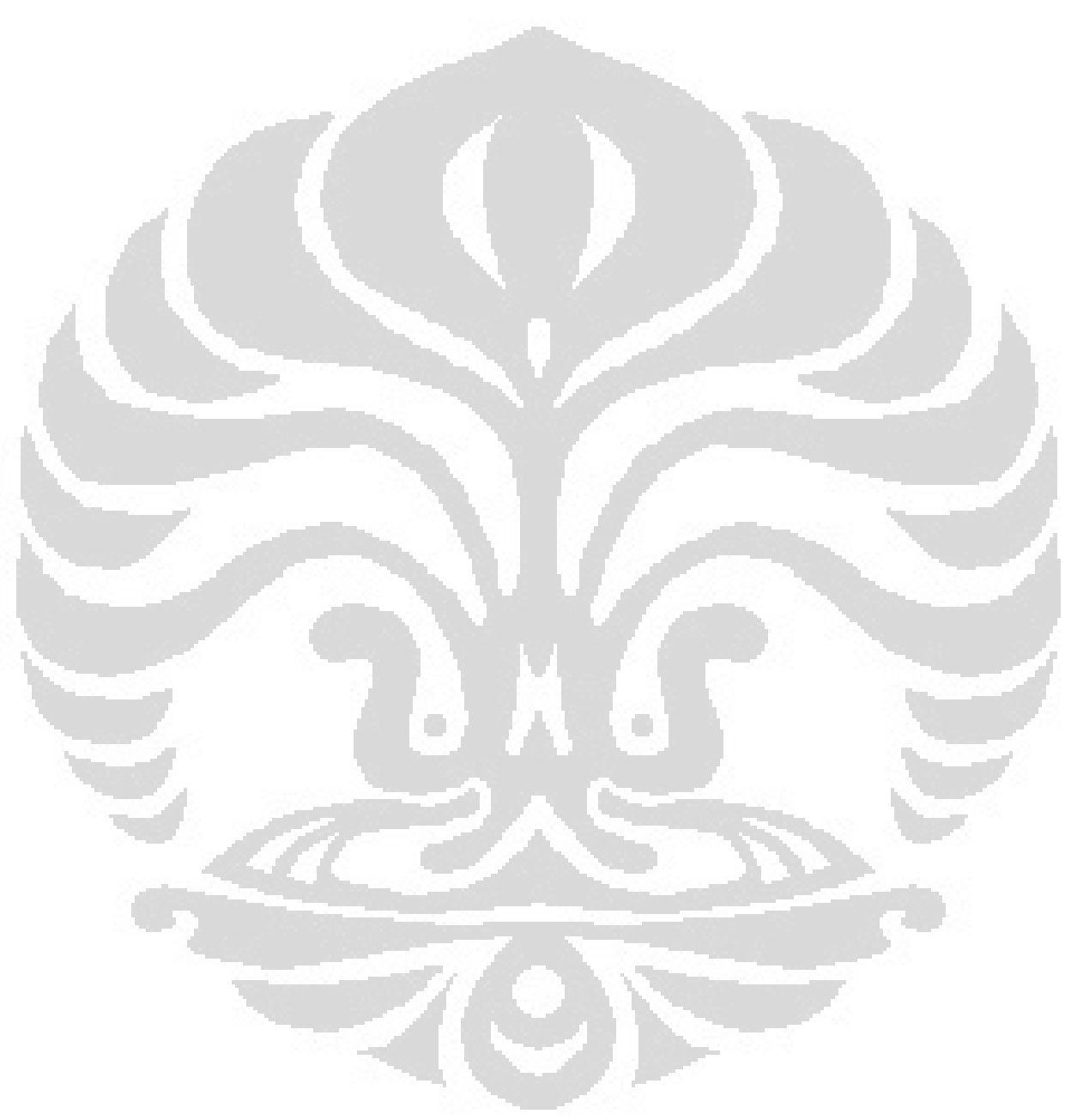

